Language in Africa 1(3), 2020, 17-99. doi: 10.37892/2686-8946-2020-1-3-17-99

\title{
THE JEN LANGUAGE CLUSTER: A COMPARATIVE ANALYSIS OF WORDLISTS
}

\author{
Russell Norton \\ Theological College of Northern Nigeria and SIL International \\ russell_norton@sil.org \\ Nlabephee Othaniel \\ Theological College of Northern Nigeria and Initiative for the Translation \\ and Development of African Languages (ITDAL) \\ othaniel_nlabephee@linguamail.org
}

\begin{abstract}
A lexicostatistical analysis divides the Jen language cluster into two primary branches Burak-Loo-Maghdi-Mak and Kyak-Moo-Leelau-Tha-Doso-Dza. This is also supported by extensive isoglosses, replacing the older Bikwin-Jen division at least for purposes of genetic classification. For vowels, a 9-vowel system is reconstructed, but its 3-way height contrasts appear unstable in some languages, either in the central vowels or in the front and back vowels. Front and back vowels also vary widely with diphthongs. Prosodic features of nasalisation, tone, and breathiness are reconstructed, with nasalisation developing in more roots in the second primary branch. For consonants, the large inventory includes particularly unstable coronals, and development of voiceless approximants in Doso-Dza. The comparative evidence is conflicting as to whether labialised and palatalised structures are secondary modifications or onset sequences, suggesting the need for a variationist approach. Overall, riverine Jen varieties Tha, Doso, Dza show unusually extensive sound change, in contrast to the more phonologically stable Bikwin varieties. Applications to orthography development include the need to represent implosives and $/ r /$ in languages other than Dza, where they have been lost, and the need to represent vowel nasalisation and $/ \mathrm{h} /$ in languages of the second branch only. Initial stem consonant alternations seen in both nouns and verbs need more investigation in Jen languages.
\end{abstract}

Key words: Jen, language cluster, Bikwin, lexicostatistics, reconstruction, orthography 


\section{Introduction}

The Jen language cluster conventionally consists of the ten Adamawa language varieties listed in Table 1, that are considered immediately genetically related as well as geographically adjacent (Eberhard et al. 2019). Hyphenated names in the literature, Burak-Jen (Bennett 1983) or Bikwin-Jen (Kleinewillinghöfer 1996), refer to the same cluster. ${ }^{1}$

Table 1

\section{Jen varieties with ISO639-3 identifier codes and elicited autonyms}

[bys] Burak [6ū:ràk]

[ldo] Loo (Shungo Galdemaru, [ Scònó]; [lō] 'head'

[gmd] Maghdi (Tala) [màkdī], [mâydī]

[pbl] Mak (Lee Mak) of Panya [màk], [lè màk] 'they (of) Mak'
and Zoo

[bka] Kyak (Bambuka) [kjã̃k]

[gwg] Moo (Gomu) [m̄̄]

[ldk] Leelau (Munga Leelau) [lê ləù] 'road (to) Lau'

[mko] Munga Doso [mingã doso] 'river original'

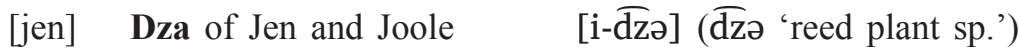

[thy] Tha (Joole Manga) [ð̀̀], [nwá ðá] (nwá 'mouth')

${ }^{1}$ Hammarström et al. (2019) add Baa (that is, Kwa [kwb]) as an "unclassified Bikwin-Jen language", citing Kleinewillinghöfer (1996). This seems an optimistic reading of Kleinewillinghöfer, however, who reports only that Kwa is typologically similar to Bikwin-Jen in its pluralisation strategy (1996: 98), and that Kwa lexicon resembles Adamawa languages in general (1996: 99), neither of which is evidence of a Bikwin-Jen affiliation. 


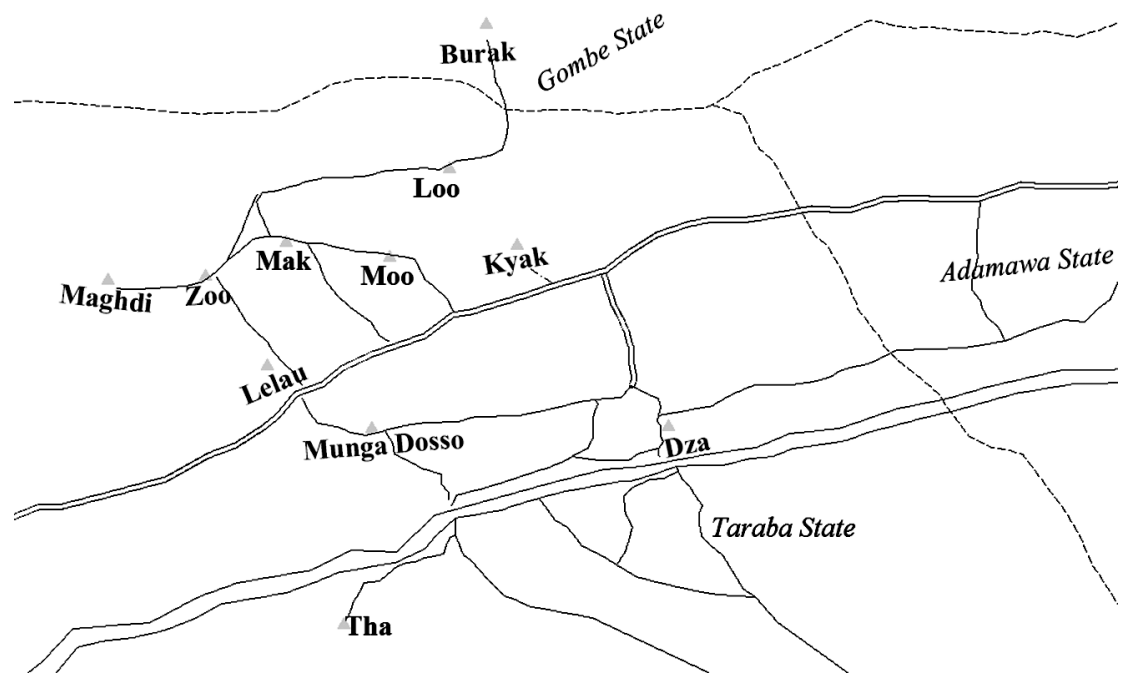

Figure 1. Map of the Jen language cluster (Othaniel 2017)

Recurrent elements in the variety names include Munga /min-gã/ 'river' (lit. 'big water') used by two adjacent riverine communities, one of which asserts they are original (Doso) to the area, and the other is on the road to Lau (Leelau). The ancestral name Mak [màk] is also present in Maghdi [màkdī], [mâydì], the latter with postvocalic allophonic variant [y] as also observed in the Maghdi word list, [wòyməì] 'shoe', [ğbáyà] 'scratch'.

The varieties are spoken between the Benue river and the Gombe/ Taraba State border to the north (Figure 1). The Jen language cluster is in an area of high linguistic diversity, next to other Adamawa languages spoken in the east (Dadiya, Bangwinji, Tso, Kwa), West Chadic languages in the north and west (Tangale, Pero, Kushi, Kholok, Nyam), a Jarawan Bantoid language in the south-west (Kulung), Jukunoid languages (Shoo-Minda-Nye, Jiba) in the south, and a Central Sudanic language (Laka) in the south. The Central Chadic language Bachama is spoken to the east, but some of its speakers are settled in villages in the Jen language cluster area. The Atlantic language Fulfulde 
is spoken by herders throughout the area. Hausa is present throughout the area as a language of wider communication, and English is present in schools and other formal settings.

In their morphological type, the Jen languages lack the noun class suffixes found in other Adamawa languages. Instead, pluralisation is expressed by the use of a 3 PL pronoun before the noun. In Dza, where nouns begin with either a consonant or $i$, the noun may cliticise to the pronoun $\grave{e}$ causing removal of the noun's initial vowel, producing an incipient $i / e ̀$ alternation on $i$-initial nouns as shown in (1).

(1) Plural pronoun cliticisation in Dza

\begin{tabular}{|c|c|c|c|c|}
\hline$f_{t}$ & 'person' & è $f f t$ & $\sim e ̀ f f t$ & 'people' \\
\hline wò & 'child' & è ímwò & 〜 èmwò & 'children' \\
\hline & 'male' & 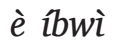 & $\sim e \grave{e} b w \hat{\imath}$ & 'males' \\
\hline & 'female' & è íhè & 〜 èhê & 'females' \\
\hline
\end{tabular}

Across the Jen language cluster, various plural roots $e$, le, ye, yá, yila, or nó are used in this construction as shown in (2), often with vowel lengthening before the following noun, and/or initial vowel elision in the following noun. ${ }^{2}$

${ }^{2}$ The form le is also seen in Table 1, Lee Mak. Problematic in this respect is the name Leelau, as le is not used for the associative plural in Leelau in (2), nor do we have it in our Leelau wordlist for 'they', but Kleinewillinghöfer (1996: 96) provides the meaning of Leelau as 'road (to) Lau' (see *le 'road' in our Appendix). Across the Jen language cluster, pronominal le is found either in the plural construction in (2) or for 'they' in our word list in Maghdi, Mak, Doso and Dza, widespread enough to support reconstruction of *le 3PL, although it is unattested in Kyak-Moo-Leelau. Likewise, ye appears either in the plural construction or in the word list in Moo, Maghdi, Mak, and very similar $e$ in Dza, supporting the reconstruction of *ye 3PL as well in alternation with *le. Another 3PL root *ní or similar appears in our word lists, but is not used in the plural construction (unless Tha nó is somehow derived from ní). 
(2) Pluralisation of 'man' in Jen varieties (Kleinewillinghöfer 1995/2015)

Dza ibùì / ee ibwì

Doso yíbui / lé-bui

Tha nimbi / nó nimbi

Kyak yibé / yáá yìbe

Moo yibé / yá yìbe

Leelau yibéí / yáá-bei

Mak libei / lee labei (but yuluy / yee yuluy 'bird / birds')

Maghdi libei / lee labei (but yuluy / yee yulun 'bird / birds')

Loo lua libe / yila liba

Burak libe / yelaa libe

The present work is a study of sound correspondences between Jen language varieties, based on a comparative 300 wordlist collected by the second author for his BA thesis (Othaniel 2017). Our goal is to identify sound changes in the cluster and provide proto-Jen reconstructions for the items in our word list. The purpose of this study is to contribute to knowledge of the history of Adamawa languages, and also to gain insights from sound correspondences that can support efficient development of orthographies for the Jen languages (Norton \& Othaniel 2018). A past-ward orientation in historical linguistics leads back to reconstruction, and a present-ward orientation leads forward to the speech forms used today, and to how these can be represented in writing. The latter is an implementation of the idea in Lewis and Stalder (2010) that language clusters can undergo co-ordinated development based on their linguistic similarity. Dza (or Jenjo ${ }^{3}$ ) has been written since 2000 through the Jenjo Language Development Project, and the phonemes are analysed in detail in Othaniel (2016). Hence, sound changes that differentiate Dza from the other varieties

${ }^{3}$ Jenjo is the Fulfulde word for a Dza speaker, consisting of the town name Jen and the Fulfulde person suffix $-j o$. 
reveal how the Dza orthography would need to be adapted in order to write other languages of the Jen cluster in a phonemic orthography. A related question is how many other language units are candidates for development among the varieties listed for the Jen language cluster, as some varieties are actually extremely similar (Kleinewillinghöfer 2017). We consider this point using a preliminary lexicostatistical assessment prior to the analysis of sound correspondences.

We begin with a lexicostatistical assessment of the language cluster in $\S 2$, using a comparative Swadesh 100 wordlist for the Jen varieties available online (Kleinewillinghöfer 1995/2015). In $\S 3$ and $\S 4$, vowels and consonants are compared over our own 300 wordlist, followed by a conclusion in $\$ 5$. and a list of reconstructed items in the Appendix.

\section{Lexicon}

\subsection{Lexicostatistics}

Lexical similarity values between the varieties were generated using the WoRDSuRv7 program by entering cognate judgements over available Swadesh 100 wordlists for all ten varieties including two sub-varieties each of Loo, of Mak and of Dza (Kleinewillinghöfer 1995/2015). This produced the results shown in Table 2. This is a preliminary exercise in lexicostatistics (Starostin 2013), where sound correspondences and etymological structure are judged by inspection without a mature understanding of the languages. The analysis nevertheless enables us to evaluate three basic issues: status as a language cluster in terms of overall lexical cohesion, status of extremely similar varieties as dialect clusters, and intermediate relationships between different parts of the language cluster. We assume the divergences in lexicon occurred by the universal process of lexical replacement, but we do not seek to explain the replacements further as a result of word taboos, as Kleinewillinghöfer (1995) has proposed for other cultures of the Muri Mountains.

As to overall lexical cohesion, all lexical similarity values are at least $45 \%$, a level at which linguistic relationship will be evident to 


\begin{tabular}{|c|c|c|c|c|c|c|c|c|c|c|c|c|c|c|}
\hline & & & & & & & & & & & & & & \\
\hline & (oৎ)ezd & $\stackrel{n}{\forall}$ & 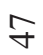 & 유 & fo & $\bar{n}$ & $\bar{n}$ & 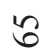 & 6 & $\tilde{6}$ & gิ & $\bar{a}$ & $\infty$ & 음 \\
\hline & (әГ)ezQ & $\underset{7}{+}$ & テ & in & テ & in & $n$ & $\underset{b}{\infty}$ & $\hat{\sigma}$ & $\hat{6}$ & $\stackrel{2}{1}$ & ஓ & ᄋ & $\stackrel{\infty}{a}$ \\
\hline$\stackrel{0}{i}_{\infty}^{0}$ & osod & $\stackrel{\infty}{+}$ & $\stackrel{\infty}{+}$ & $\stackrel{\infty}{+}$ & $\stackrel{0}{+}$ & N & n & $\infty$ & ำ & 6 & $n$ & 음 & ฉ & $\bar{a}$ \\
\hline 를 & вЧL & $n$ & ก & $\bar{n}$ & in & in & 8 & 6 & ชิ & $\tilde{6}$ & 8 & $m$ & $\stackrel{2}{R}$ & gิ \\
\hline in & пв[әәТ & 요 & $\stackrel{\infty}{+}$ & 유 & $n$ & す & 6 & a & $\infty$ & 8 & 6 & రి & 6 & $\hat{6}$ \\
\hline 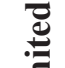 & о0W & N & gิ & $\vec{n}$ & $\stackrel{\infty}{n}$ & $\overline{6}$ & ำ & ส & 8 & $\infty$ & ำ & ชู & $\tilde{\sigma}$ & 6 \\
\hline$\stackrel{0}{0}$ & YeरY & n & n & $m$ & $\overline{6}$ & 6 & 6 & 8 & ๙ & n & 6 & $\infty$ & $\infty$ & 6 \\
\hline$\ddot{8}$ & (Z)yв & $N$ & 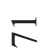 & $\nabla$ & $\infty$ & $\hat{a}$ & 8 & 6 & రె & $\tilde{6}$ & ? & n & $n$ & $\bar{n}$ \\
\hline$\Xi$ & (d)YeW & $\bar{N}$ & $N$ & $\vec{N}$ & $\dddot{\infty}$ & 으 & $\hat{a}$ & 6 & 6 & オ & n & n & $n$ & $\bar{n}$ \\
\hline స్ & !рчภิвW & হ & 0 & $\frac{6}{1}$ & $\stackrel{8}{\varrho}$ & $\infty$ & 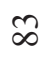 & $\overline{6}$ & $\stackrel{\infty}{n}$ & in & in & $\stackrel{+}{q}$ & テ & f \\
\hline$\ddot{\Xi}$ & $(M)^{00} \mathrm{~T}$ & $\infty$ & n̊ & $\stackrel{8}{\varrho}$ & 2 & $\bar{N}$ & $\bar{N}$ & $n$ & $\bar{n}$ & $\stackrel{\circ}{n}$ & $\vec{n}$ & $\stackrel{\infty}{+}$ & 요 & 요 \\
\hline ల్ల & (D)00 T & ๙ૅ & 8 & ตุ & 2 & $N$ & $\bar{N}$ & n & gे & $\stackrel{\infty}{+}$ & N & $\stackrel{\infty}{+}$ & $\nabla$ & テ \\
\hline & ye.Ing & 8 & ส & $\infty$ & 2 & $\bar{N}$ & $N$ & in & N & $\stackrel{\circ}{n}$ & $n$ & $\underset{\forall}{\infty}$ & $\underset{+}{+}$ & $\stackrel{n}{\forall}$ \\
\hline & & 气ै & 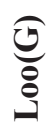 & 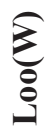 & 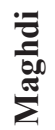 & 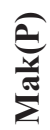 & 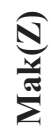 & है & $\frac{8}{2}$ & త్ర & $\underset{\boldsymbol{I}}{\boldsymbol{E}}$ & $\begin{array}{l}\text { ஜ̂ } \\
\text { ̊̊ }\end{array}$ & 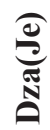 & 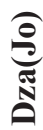 \\
\hline
\end{tabular}


both linguists and speakers alike (Gell-Mann, Peiros \& Starostin 2009: 14). This sufficient lexical cohesion, combined with their geographical contiguity, supports the description "language cluster".

As to dialect clustering, there is extremely high similarity between the two sub-varieties of Loo, of Mak and of Dza (at least 95\%). But there is also very high similarity between Burak and Loo, between Kyak, Moo and Leelau, and between Doso and Dza. In each of these groupings, all lexical similarity values are above the threshold of $85 \%$ indicated in Eberhard et al. (2019) for dialecthood. However, this threshold should be considered together with other criteria for dialect status, and ultimately the issue can only be settled by the communities themselves. Here, we can only make preliminary observations. Geographically, Burak-Loo and Kyak-Moo form adjacent groupings so that they are able to function as larger speech communities, but the political separation of Burak and Loo by the Gombe/Taraba state boundary, and the geographical non-contiguity of Leelau with KyakMoo, partly compromise their respective cohesion. For Doso and Dza, extensive phonological differences make them noticeably less cohesive in their lexicon, despite their many cognates.

As to intermediate relationships, the varieties combine into successively larger subclusters according to lexical similarity, as represented by boxes in Table 3. At $80 \%$ similarity, the varieties form five clear groups, Burak-Loo, Maghi-Mak, Kyak-Moo-Leelau, Tha, and Doso-Dza. At 70\% similarity, Burak-Moo combines with Maghdi-Mak, and Tha combines with Doso-Dza. At the $60 \%$ stage, the remaining subgroup Kyak-Moo-Leelau clusters with Tha-Doso-Dza to the right rather than with Burak-Loo-Maghdi-Mak to the left, as it consistently scores at $60 \%+$ similarity with Tha-Doso-Dza. The lexicostatistical analysis therefore departs from the previous view distinguishing a Bikwin group consisting of the first seven varieties (Kleinewillinghöfer 1996: 92-94). Scores between Kyak-Moo-Leelau and Burak-LooMaghdi-Mak are much more variable, peaking at $66 \%$ between Kyak and Mak, but as low as $48 \%$ between Leelau and Loo, which is no higher than the base level of the whole language cluster. Hence, 


\begin{tabular}{|c|c|c|c|c|c|c|c|c|c|c|c|c|c|c|}
\hline & & & & & & & & & & & & & & \\
\hline & (or)eza & $\stackrel{n}{\vee}$ & テ & 요 & \& & $\vec{n}$ & $\vec{n}$ & 6 & $\overline{6}$ & $\tilde{6}$ & ఠิ & $\bar{a}$ & $\infty$ & $\stackrel{\varrho}{0}$ \\
\hline & (әг)вz & $\underset{7}{+}$ & 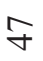 & $\stackrel{\circ}{n}$ & $\stackrel{\nabla}{\sigma}$ & $n$ & $n$ & $\infty$ & $\tilde{\sigma}$ & $\widehat{\sigma}$ & $\stackrel{2}{1}$ & ๑̊ & $\stackrel{8}{\varrho}$ & $\stackrel{\infty}{\alpha}$ \\
\hline$\stackrel{0}{0}$ & osod & $\stackrel{\infty}{+}$ & $\stackrel{\infty}{+}$ & $\stackrel{\infty}{+}$ & $\stackrel{\circ}{+}$ & n & n & $\infty$ & ชู & రి & $m$ & $\stackrel{8}{\varrho}$ & ฉ̊ & $\bar{a}$ \\
\hline$\stackrel{\ominus}{\ominus}$ & вपL & $n$ & n & $\vec{n}$ & in & n & ?ำ & 6 & ชิ & 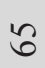 & 8 & $m$ & $\stackrel{2}{2}$ & a \\
\hline$\stackrel{\ominus}{\ominus}$ & nв[әәТ & 요 & $\stackrel{\infty}{+}$ & 요 & in & オ & $\tilde{6}$ & n & $\infty$ & 8 & 6 & 6 & $\widehat{6}$ & $\tilde{\sigma}$ \\
\hline 를를 & ооW & N & g & $\bar{n}$ & $\stackrel{\infty}{n}$ & $\overline{6}$ & $\widetilde{\sigma}$ & ๙ & 8 & $\infty$ & $\widetilde{\sigma}$ & ชื & $\tilde{\sigma}$ & 6 \\
\hline$\stackrel{\varrho}{\Xi}$ & Yек्र & N & n & $n$ & $\overline{6}$ & 6 & 6 & $\stackrel{8}{\varrho}$ & ๙ & $a$ & 6 & $\approx$ & 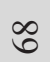 & 6 \\
\hline$\frac{1}{\vec{b}}$ & (Z)увW & $N$ & $\nabla$ & $\bar{N}$ & $\infty$ & $\hat{a}$ & 8 & 6 & ㅈ & 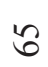 & ?ำ & n & $n$ & $\bar{n}$ \\
\hline 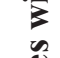 & (d)Ув & $\nabla$ & $N$ & $\bar{R}$ & $\infty$ & 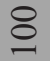 & $\hat{a}$ & 6 & $\overline{6}$ & オே & 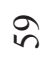 & n & in & $\bar{n}$ \\
\hline$\stackrel{\pi}{>}$ & !рપริยW & 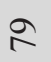 & 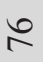 & 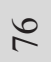 & 8 & $\infty$ & $\infty$ & $\overline{6}$ & $\begin{array}{l}\infty \\
n\end{array}$ & in & 6 & \& & $\nabla$ & f \\
\hline$\stackrel{\pi}{\Xi}$ & (M)00 T & $\infty$ & $\curvearrowleft$ & 8 & 0 & $\bar{N}$ & $\bar{N}$ & $n$ & $\bar{n}$ & 요 & $\bar{n}$ & $\stackrel{\infty}{+}$ & $\stackrel{\circ}{n}$ & $\stackrel{\circ}{n}$ \\
\hline • & (D)00 T & ๙ & 8 & n & 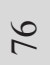 & $N$ & $\bar{N}$ & in & f & $\stackrel{\infty}{+}$ & in & $\stackrel{\infty}{\forall}$ & $\nabla$ & テ \\
\hline & Ye.Ing & $\stackrel{\varrho}{\varrho}$ & ๙ & $\infty$ & 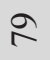 & $\vec{N}$ & $N$ & n & N & 요 & $n$ & $\stackrel{\infty}{+}$ & $\underset{7}{+}$ & $\stackrel{n}{7}$ \\
\hline & & صี & త్రુ & $\sum_{8}^{8}$ & 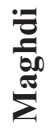 & 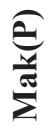 & $\underbrace{\mathbb{N}}_{\frac{\mathbb{N}}{\mathbb{N}}}$ & $\underset{\vec{z}}{\vec{\pi}}$ & $\stackrel{8}{\varepsilon}$ & 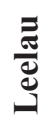 & 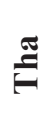 & ஜ & 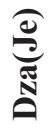 & 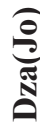 \\
\hline
\end{tabular}


although Bikwin varieties can be grouped together geographically (those communities away from the Benue river in the western Muri Mountains) and culturally (6i kwin 'we (are) one'), they are not a genetic group. The genetic unity of Kyak-Moo-Leelau with Tha-Doso-Dza implies a migration by the ancestors of Kyak-Moo-Leelau away from the riverine Jen area towards the settlements of Mak, Maghdi, Loo and Burak. After this, Mak must have increased in similarity to Kyak-MooLeelau due to contact. While the data in the rest of this paper and in the comparative word list in the Appendix frequently divides BurakLoo-Maghdi-Mak and Kyak-Moo-Leelau-Tha-Doso-Dza, there are also quite a few examples where Mak patterns with the last six varieties. ${ }^{4}$

The lexicostatistical analysis is presented in tree format in Figure 2, annotated with branch-average percentage values for three dialect clusters and for the Jen language cluster as a whole. All sub-branches in this tree are supported by sound changes presented within the rest of this paper.

${ }^{4}$ An observation that we pass over in our hierarchical cluster analysis of the lexical similarities is that Kyak-Moo-Leelau is much more distant from the BurakLoo portion of the first branch (48-53\%) and noticeably closer to the Maghdi-Mak portion $(57-66 \%)$. A reviewer points out that the latter numbers are similar to Kyak-Moo-Leelau's closeness to Tha-Doso-Dza (61-68\%), that determines the final division between the first four varieties and the last six varieties. Although Kyak-Moo-Leelau cannot be hierarchically grouped with Maghdi-Mak because Maghdi-Mak is much closer to Burak-Loo, the data can nevertheless support a chain analysis linking one dialect cluster to the next (Burak-Loo $=$ MaghdiMak $=$ Kyak-Moo-Leelau $=$ Tha-Doso-Dza). This has the very plausible implication that effects of contact between adjacent Jen varieties extends into the past to the proto-varieties that produced the present dialect clusters, which is just what we should expect in a language cluster environment. Nevertheless, the isoglosses and correspondences in the rest of the paper follow the divisions made in the hierarchical analysis. Thus, although we acknowledge that the chain interpretation provides additional historical insight, we also consider that the hierarchical interpretation still stands. The hierarchical interpretation provides a model of the successive formation of more and more Jen speech communities as traced in their diverging lexical choices, whereas under the chain interpretation the formation of these communities is assumed rather than explained. 


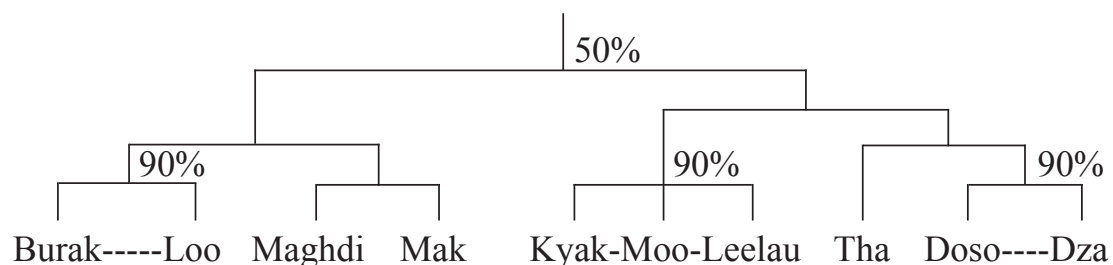

Figure 2. Jen language cluster tree

\subsection{Isoglosses for the two primary branches}

The proposed primary branching between the first four varieties and the last six varieties, revising the earlier Bikwin-Jen division, can be defended by evidence from various isoglosses. Some of the items considered here were already used at an earlier stage of research as evidence of a close connection between Bikwin and riverine Jen (Tha, Doso and Dza) because the links were especially evident between ThaDoso-Dza and Kyak-Moo-Leelau (Kleinewillinghöfer 1996: 96). Table 4 presents lexical isoglosses for the two revised branches. ${ }^{5}$

Table 5 presents items that show two phonological isoglosses that distinguish the second branch, nasalised vowels and [h]. Exceptionally, nasalised vowels occur in some roots in Mak of the first branch as well ('suck', 'many'). This can be attributed to borrowing, however, which is already invoked in $\S 2.1$ to explain the inflated lexical similarity of Mak to Kyak-Moo-Leelau.

Table 6 presents verbs with a different initial consonant in the two branches. The consonants $j / w, j / z, w / z, n / z$ are phonetically dissimilar and thus represent verbal stem alternations of unknown function. The item 'split' even attests alternation between $s$ and zero.

Table 7 presents roots with a recurring difference *-e/*-in (or ${ }^{*}$-we/*-i $)$ in their rhymes between the two branches, again of unknown function. This assumes that $* e$ is sometimes realised by a diphthong a $i$ or similar (\$3.2), and that ${ }^{*} i$ becomes $u$ after a labial consonant in Kyak-Moo-Leelau.

${ }^{5}$ Here and in all our collected data, the IPA symbol [j] is transcribed for the palatal approximant. 


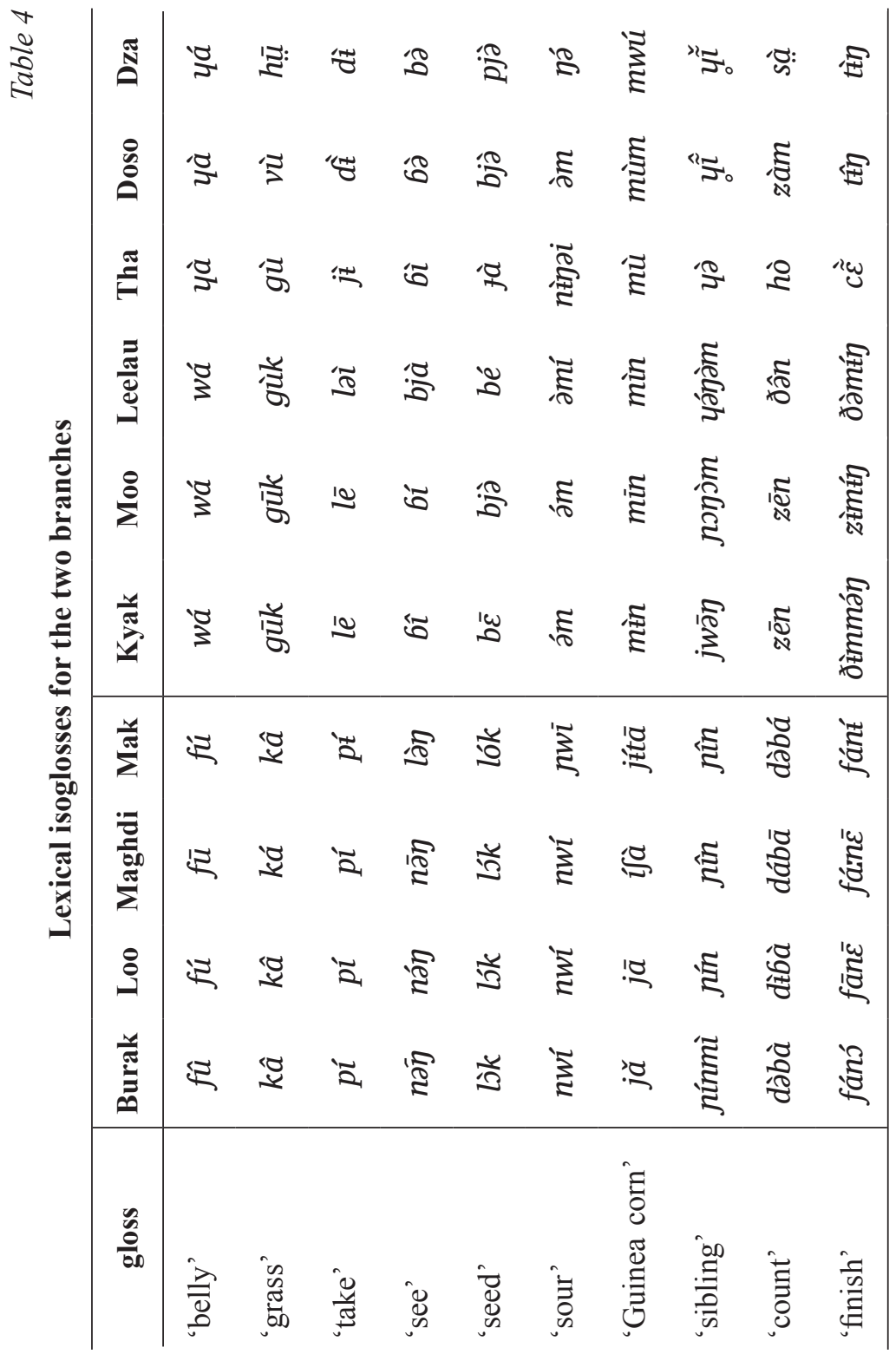




\begin{tabular}{|c|c|c|c|c|c|c|c|c|c|c|}
\hline \multirow{11}{*}{ 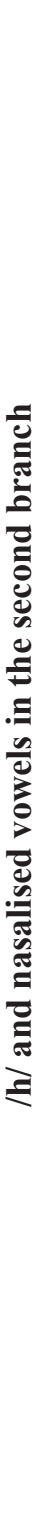 } & నิ & 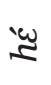 & "ָּ & "వ్ల & "ర్ర & $\stackrel{12}{3}$ & & 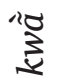 & דים & \\
\hline & ஜ̊ & $\tilde{\mathbb{2}}$ & 'ָּ & 占 & ס్రా & $(\sqrt[3]{\infty}$ & & & ג' & ) \\
\hline & $\stackrel{\underline{\Xi}}{E}$ & $\stackrel{0}{\sim}$ & "న్ల & "న్ & ס్రిల్ల & & "7 & & న్న & \\
\hline & 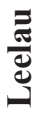 & 'ర్ల & 蛋 & $\sqrt{0}$ & "ే & ") & & & 放 & 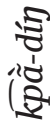 \\
\hline & $\frac{8}{2}$ & 溮 & 'ڤ & in & "8 & |W & & & న & 20 \\
\hline & 光 & 'ర్ల & 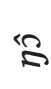 & "ת & ס & (ָ) & & \begin{tabular}{l}
0 \\
3 \\
\multirow{2}{*}{}
\end{tabular} & 放 & (ס) \\
\hline & $\frac{\mathscr{v}}{\tilde{J}}$ & 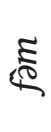 & ת' & 胥 & $\frac{\sqrt{6}}{\sum_{\infty}}$ & $\vec{\sim}$ & & & 湑 & in \\
\hline & 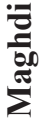 & 分 & 岕 & 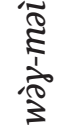 & م) & స & & ס) & & \\
\hline & 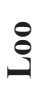 & 这 & 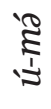 & 疍 & $\underset{\mathfrak{E}}{\stackrel{\Xi}{\Xi}}$ & $\tilde{2}$ & & $\frac{1}{10}$ & 'Z̃ & \\
\hline & 里 & $\underset{2}{2}$ & 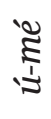 & 点 & 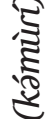 & & 涼 & & & \\
\hline & $\frac{2}{60}$ & $\sum_{0}^{\infty}$ & 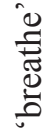 & $\frac{\mathscr{8}}{\frac{8}{6}}$ & ق. & 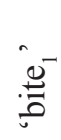 & $\overbrace{0}^{\infty}$ & 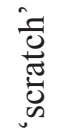 & $\frac{i}{0}$ & 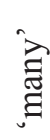 \\
\hline
\end{tabular}




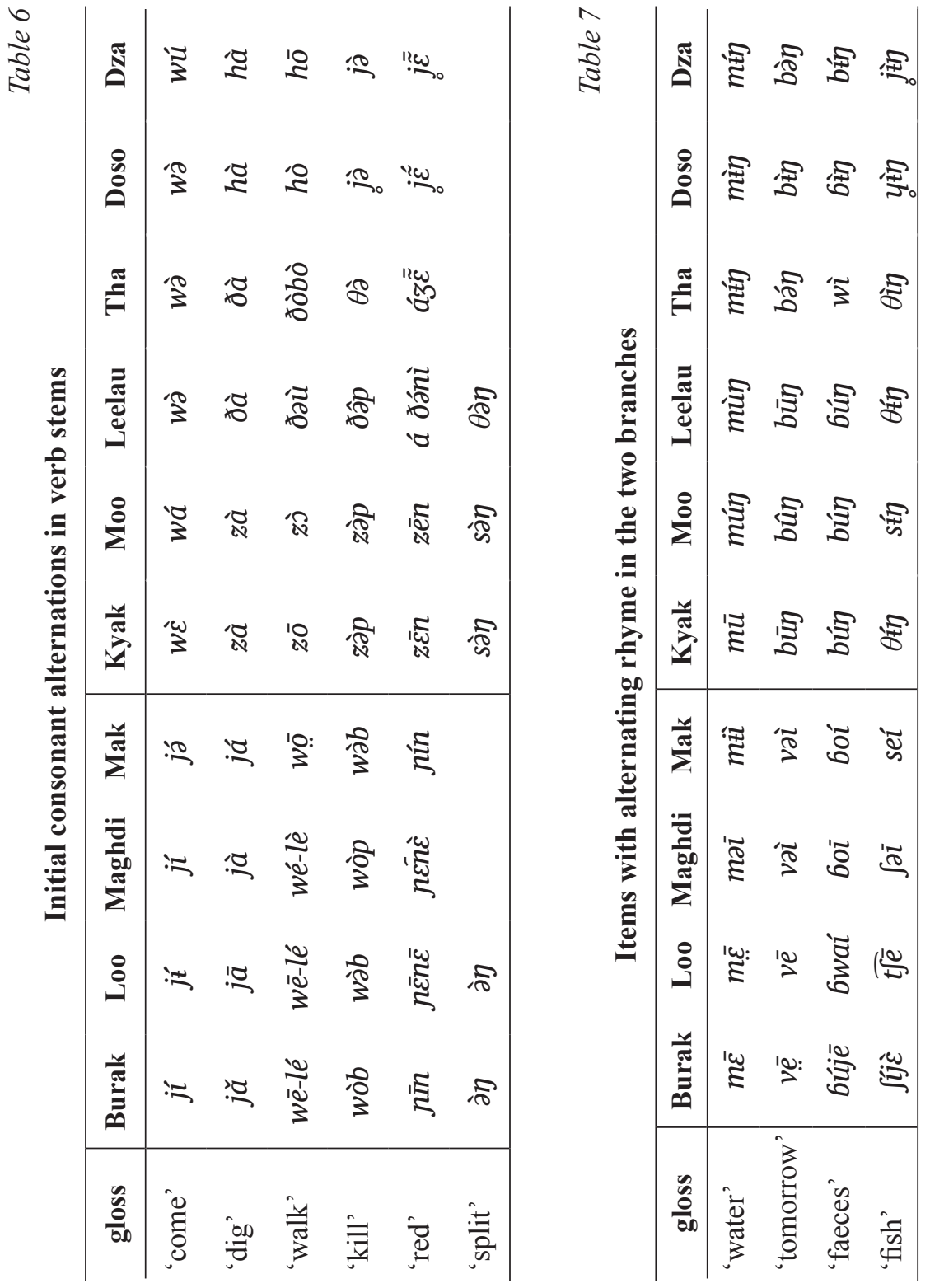


The sound correspondences in the rest of the paper show many other instances where a difference occurs between the first four varieties and the last six varieties. ${ }^{6}$

\section{Vowels}

We reconstruct a 9-vowel system *i, *e, *c, *i, *a, *a, *0, *o, *u. This means the Jen language cluster is of the three central vowels type, also seen in Central Chadic languages of the Bata group to the east of the Jen cluster (Ornan 2016; Gravina 2014: 147; Boyd 2002). More problematic are the non-high front and back vowels *e, *o, * $\varepsilon$, *o. We deal with the other more stable vowels first.

Table 8

Proto-Jen vowels

\begin{tabular}{cccc}
\hline & front & central & back \\
\hline high & $* \mathrm{i}$ & $* \dot{\mathrm{i}}$ & $* \mathrm{u}$ \\
mid & $*_{\mathrm{e}}$ & $*^{\circ}$ & $*_{\mathrm{o}}$ \\
low & $* \varepsilon$ & $*_{\mathrm{a}}$ & $* \mathrm{y}$ \\
\hline
\end{tabular}

\subsection{Stable vowels}

Stable vowels in the Jen language cluster are $* i, * u, * a, * \partial$, $* \dot{i}$ as shown in Table 9. Stable examples are shown for $* i, * u, * a$ in open syllables. An example of $*^{*} \dot{i}$ is also given which is unstable in Kyak

${ }^{6}$ Set against the ample evidence for this branching are certain lexical items that distinguish the first seven Bikwin varieties from the last three riverine Jen varieties, notably 'one', 'two', 'head', 'neck', 'tooth' (Kleinewillinghöfer 1996: 95-96). However, none of these establish Bikwin as a genetic group, either because the root is actually cognate in the last three varieties but with comprehensive changes ( $k$ win $>$ tsin 'one', dul $>$ dzwi 'neck', le $>d i$ 'tooth'), or because the root is found in other Adamawa languages as well (kwin 'one', rab 'two', lo 'head'), and so are not unique to Bikwin. 


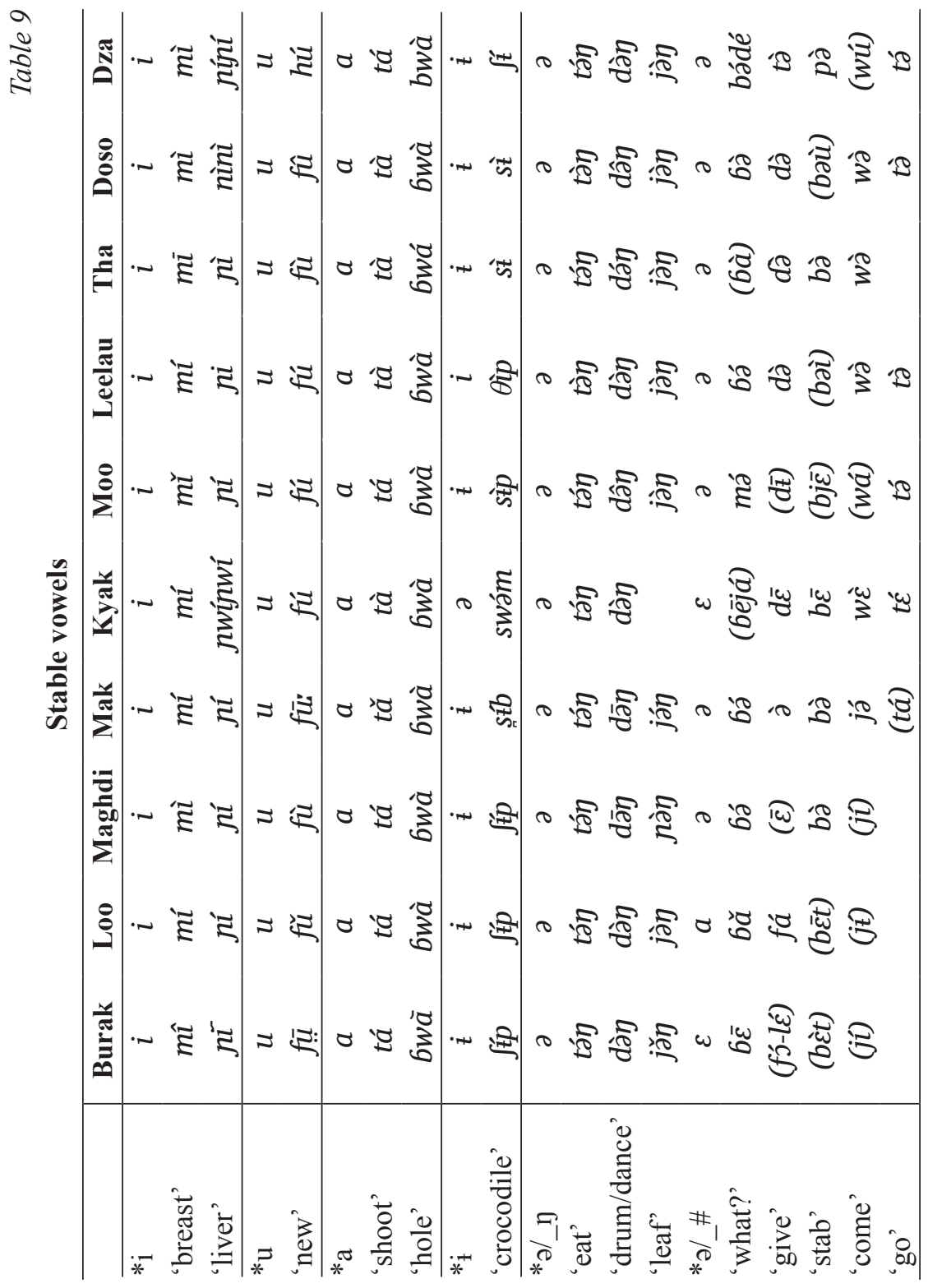


and Leelau. The schwa * $\Rightarrow$ is shown to be stable before * $y$, but this fails to provide contrast with * $a$, for which there are no stable examples before ${ }^{*} \eta$ in our wordlist. However, examples in open syllables confirm a contrastive schwa *o in most varieties except Burak-Loo and Kyak, with a regular shift to $[\varepsilon]$ in Kyak.

Table 10 illustrates that ${ }^{*} i$, * $u$ are centralised to [i] in closed syllable roots in several varieties of the second branch. This seems to be conditioned by the following consonant in opposite ways in Kyak and Moo. The restriction to closed syllables is confirmed by the failure of centralisation in roots where the final consonant is lost in Tha, Doso and Dza. Centralisation co-exists with contrary processes where ${ }^{*} i$ becomes [ə] or [i] (Table 9) or [u] after a labial consonant (Table 7) in Kyak-Moo-Leelau, increasing the probability that contrast between [i] and neighbouring sounds has been lost in Kyak-MooLeelau.

Table 11 shows that the high back vowel undergoes diphthongisation $* u>w i$ in open syllables after an alveolar consonant, particularly in Doso-Dza, but that * $u$ is also renewed in Doso-Dza by mid vowel raising ${ }^{*} o>u$ in open syllables (also in $\S 3.2$ ).

\subsection{Non-high front and back vowels}

Non-high front and back vowels are problematic for two reasons. The first problem is the lack of stable correspondences contrasting ${ }^{*} e^{-}{ }^{*} \varepsilon$ and ${ }^{*} O-{ }^{*} 0$ consistently across the language cluster. The second problem is that these vowels frequently occur in irregular correspondences with diphthongs.

ATR contrast in mid vowels is reported in Dza, with incompatibility between +ATR /e o/ and -ATR / $\varepsilon$ J/ in the same root (Othaniel 2016), but this is not straightforwardly replicated across the language cluster by stable correspondences. The distinction can be reconstructed in open syllable roots, but is subject to many sound changes. There is also comparative evidence for a phonological distinction of height as an alternative to ATR, as /عJ/ pattern with the low central vowel /a/ in 


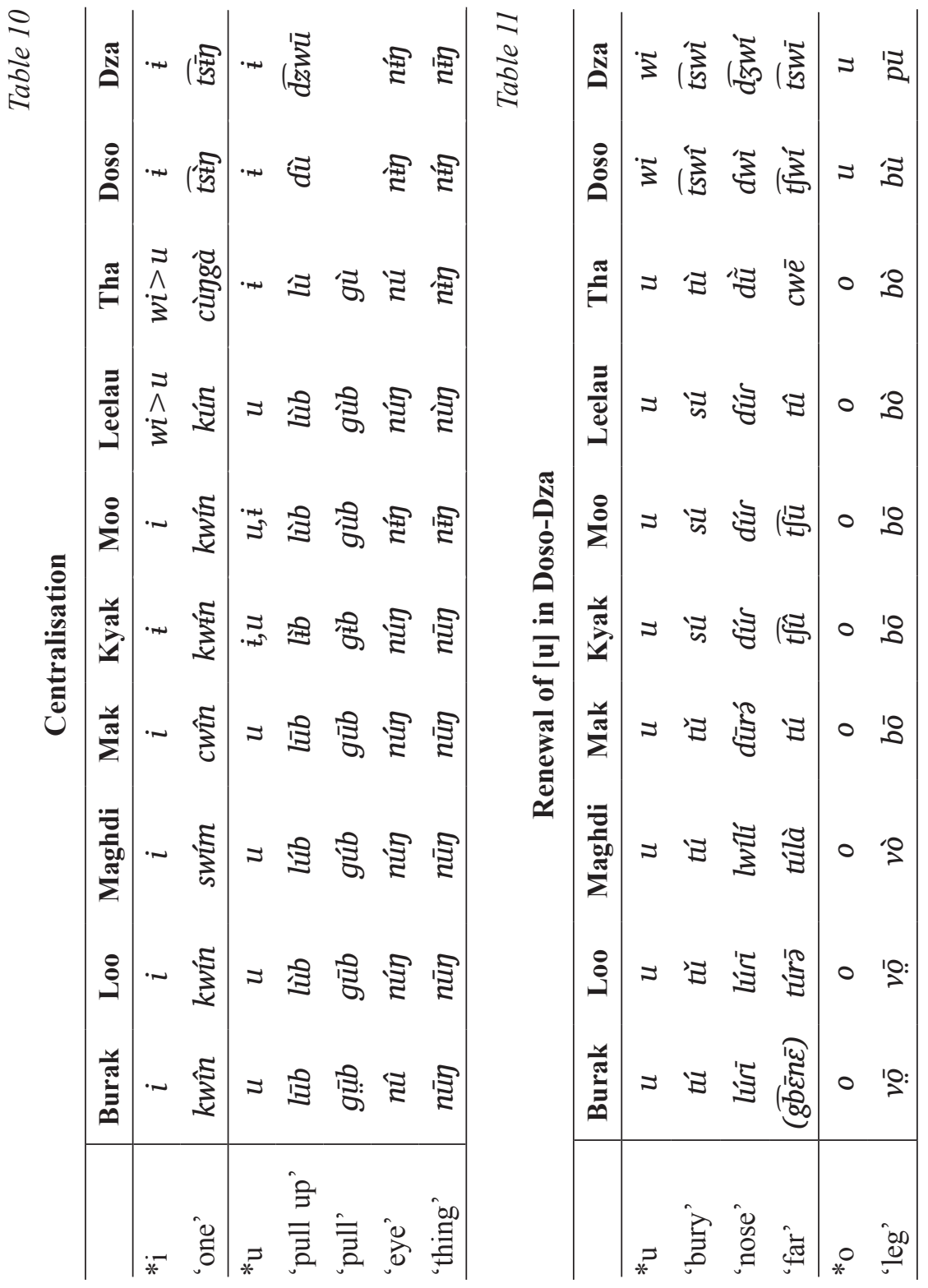


some data (Tables 11 and 12). ${ }^{7}$ The contrasts are most visible in BurakLoo on the left of the table (also in Kleinewillinghöfer 1995/2015), becoming unstable to the right of Burak-Loo, and with nearly all instances of these vowels changing in Doso-Dza. It is surprising, then, to find these contrasts repeated in Dza. Hence, although from a comparative perspective, the contrast is compromised by sound changes outside Burak-Loo, it would be worthwhile for research in any Jen variety to check carefully whether the contrast is lost or still present.

The non-high front and back vowels also frequently appear in irregular correspondences with various diphthongs. Table 12 shows correspondence with off-gliding diphthongs [əi] and [əu] in open syllables, although in some varieties the vowels ${ }^{*} \varepsilon$ and $* 0$ have the low central vowel in reflexes instead of the schwa, s:aw ('bow') and $\varepsilon: a / C$ ('left').

Table 13 shows roots in which all four vowels have different outcomes in the second branch. The conditioning behind these changes in the second branch is unclear. Nevertheless, the data adds support for the contrasts ${ }^{*} e-{ }^{*} \varepsilon$ and ${ }^{*} O-{ }^{*}$. The ${ }^{*} O-{ }^{*} 0$ contrast, preserved here in the Maghdi data, is strikingly confirmed by correspondence to different diphthongs [we] and [wa] respectively in the second branch. The front vowel ${ }^{*} \varepsilon$ shows a parallel correspondence to [ja] in the second branch, hence the lower vowels * $\varepsilon$, *0 pattern with the low central vowel in diphthongisation to [wa] and [ja]. There is, however, an apparent neutralisation ${ }^{*} \varepsilon \rightarrow e$ in Maghdi-Mak (compare Tables 12 and 14). The fourth vowel *e shows a different change by raising to [i], where reconstruction of the mid vowel * $e$ rather than the high vowel is also supported by its role a split in *p in Table 24 .

Table 14 shows how all four vowels raise to high vowels ${ }^{*} 0,0>u$, $* e, \varepsilon>i$ in Doso-Dza in more open syllable roots. These series also attest changes smaller changes with apparent neutralisations of contrast in Maghdi, Mak, Leelau, and Tha (compare Tables 11 and 12) as well as Doso-Dza.

${ }^{7}$ Alternatively, the distinction may be between + ATR /e ə o/ and -ATR / $\varepsilon$ a $~ /$. 


\begin{tabular}{|c|c|c|c|c|c|c|c|c|c|c|c|c|c|}
\hline & $\stackrel{\text { }}{\stackrel{\mathbf{D}}{0}}$ & 0 & 10 & $\stackrel{2}{2}$ & $\stackrel{2}{2}$ & & 苞 & 0 & (ָ) & 0 & 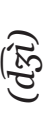 & $\stackrel{1}{\Sigma}$ & 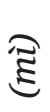 \\
\hline \multirow{10}{*}{ 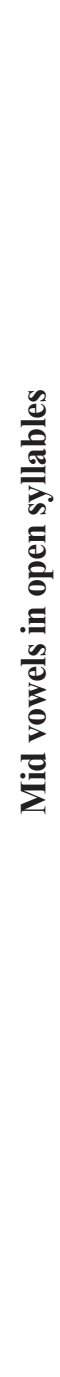 } & $\begin{array}{l}ஜ \\
\check{\mathscr{O}}\end{array}$ & 0 & O & $\stackrel{2}{2}$ & 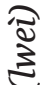 & ఏ & "ప્పે & 0 & $\mathscr{E}$ & 0 & 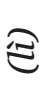 & Iِ & $\stackrel{\mathbb{E}}{\mathbb{E}}$ \\
\hline & 己 & $\begin{array}{l}\overrightarrow{1} \\
\text { న } \\
0\end{array}$ & న & . & 'ָ & ని & 'న & & & $\vec{\sigma}$ & $\tilde{\mathbb{B}}$ & 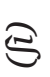 & : \\
\hline & $\frac{\bar{\Xi}}{\mathbb{d}}$ & 0 & o & : & 인 & ని & 胥 & $\tilde{\sigma}$ & $\tilde{0}$ & $\tilde{\sigma}$ & ช & $\underbrace{\stackrel{5}{5}}$ & $\tilde{\mathbb{E}}$ \\
\hline & $\stackrel{8}{\varepsilon}$ & 0 & 10 & ?ִ & 잉 & $r$ & ' & $\omega$ & 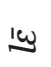 & 0 & 'f & $\stackrel{\vec{s}}{\tilde{s}}$ & 'E్ \\
\hline & है & 0 & 10 & ! & iㅇ & $\Omega$ & "D & $\omega$ & IE & $\omega$ & $\stackrel{1 \omega}{\sigma}$ & 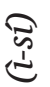 & E्E \\
\hline & $\frac{v}{\Sigma}$ & సి & : & . & 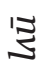 & న & : & $\tilde{\sigma}$ & $\tilde{0}$ & $\begin{array}{l}\overrightarrow{0} \\
0\end{array}$ & $\mathbb{8}$ & 勇 & $\stackrel{\mathbb{2}}{\mathfrak{E}}$ \\
\hline & $\begin{array}{l}\text { 름 } \\
\frac{\pi}{010} \\
\sum\end{array}$ & శ & . & ר & ': & స్ర & 疋 & $\tilde{\sigma}$ & 'ే & $\begin{array}{l}\overrightarrow{0} \\
0\end{array}$ & d্ & $\underbrace{10}$ & 岕 \\
\hline & $\stackrel{8}{\stackrel{\rho}{\rho}}$ & $\begin{array}{l}\overrightarrow{0} \\
\text { on } \\
\text { on }\end{array}$ & >০: & ! & 胥 & సี & 疋 & $\ddot{\sigma}$ & 'ָ & $\begin{array}{l}\vec{\omega} \\
\omega\end{array}$ & $\underset{\sigma}{|l|}$ & $\underbrace{i \tilde{0}}_{i \frac{1}{\omega}}$ & 'ָ \\
\hline & 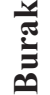 & $\begin{array}{l}\text { శె } \\
\text { on }\end{array}$ & '0 & ?ִ & 'వ' & సై & & 0 & e & $\omega$ & $\underbrace{1 \omega}_{\sigma}$ & $\underbrace{\underline{\omega}}_{\stackrel{\omega}{\omega}}$ & $\stackrel{1 \omega}{\Sigma}$ \\
\hline & & * & $\underset{\overbrace{}}{\Xi}$ & $\begin{array}{l}\text { 능 } \\
8 \\
0\end{array}$ & $\underbrace{\stackrel{0}{0}}_{\substack{0 \\
0}}$ & * & 8 & $*$ & 矛 & * & 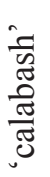 & $\frac{0}{5}$ & 5 \\
\hline
\end{tabular}




\begin{tabular}{|c|c|c|c|c|c|c|c|c|c|c|c|c|c|}
\hline \multirow{11}{*}{ 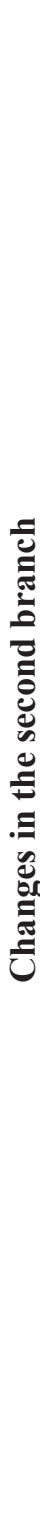 } & $\stackrel{\text { న }}{\mathbf{0}}$ & $\stackrel{3}{3}$ & '。 & 3 & ’ & $\stackrel{\sigma}{\sigma}$ & i & $\cdot \sim$ & 'న。 & 恼 & 流 & 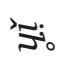 & ' \\
\hline & ஜ̊ & § & 'ָ & $\tilde{3}$ & ڤે & 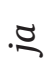 & 官 & $\sim \sim$ & 'ت & 俧 & 结 & : & $\tilde{R}$ \\
\hline & $\stackrel{\Xi}{E}$ & 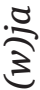 & 说 & & & סָ & ס & $\cdot \sim$ & 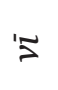 & 离 & 冰。 & $\bar{\prime}$ & \\
\hline & 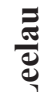 & 3 & $\sum_{\text {iे }}^{10}$ & క & 灾 & . & : ర్రా & $\sim \sim$ & '文 & 站 & 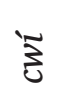 & " & $\tilde{\alpha}$ \\
\hline & $\stackrel{8}{\varepsilon}$ & 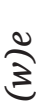 & 珗 & క్ర & ఏ్ర & . & : & $\sim \sim$ & $\sqrt{2}$ & (离 & $\underset{2}{2}$ & $\sqrt{2}$ & $\widetilde{2}$ \\
\hline & $\stackrel{\text { है }}{\text { है }}$ & $\stackrel{0}{3}$ & ऐ) & 3 & ఏે & ס ס & ס & $\cdot \sim$ & 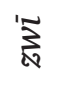 & 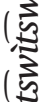 & $\frac{1}{2}$ & $\stackrel{1}{\grave{2}}$ & $\tilde{2}$ \\
\hline & $\frac{\sigma}{\Sigma}$ & $\Omega$ & 's & $\Omega$ & & 0 & ש & 0 & 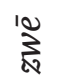 & 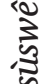 & 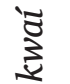 & $\frac{2}{2}$ & \\
\hline & 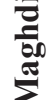 & 0 & 识 & $\Omega$ & $\stackrel{2}{2}$ & 0 & שี & 0 & ऐ্े & 3 & స్ & :ים & '气 \\
\hline & อి & 0 & & o & 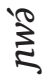 & $\omega$ & $\omega$ & 0 & \ָ & $\stackrel{2}{\Xi}$ & 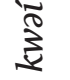 & & \\
\hline & 纤 & 0 & & $\Omega$ & '2 & $\omega$ & $\tilde{\omega}$ & 0 & 足: & ذે & $\sum_{2}^{10}$ & 3 & \\
\hline & $\frac{\tilde{\theta}}{b-0}$ & $\frac{\sum_{0}^{0}}{*}$ & 矛 & $\frac{\pi}{3}$ & 光 & $\frac{\pi}{\lambda_{*}^{j}}$ & 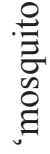 & $*$ & ర్ & 䨔 & $\overrightarrow{7}$ & $\frac{8}{8}$ & 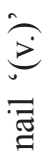 \\
\hline
\end{tabular}




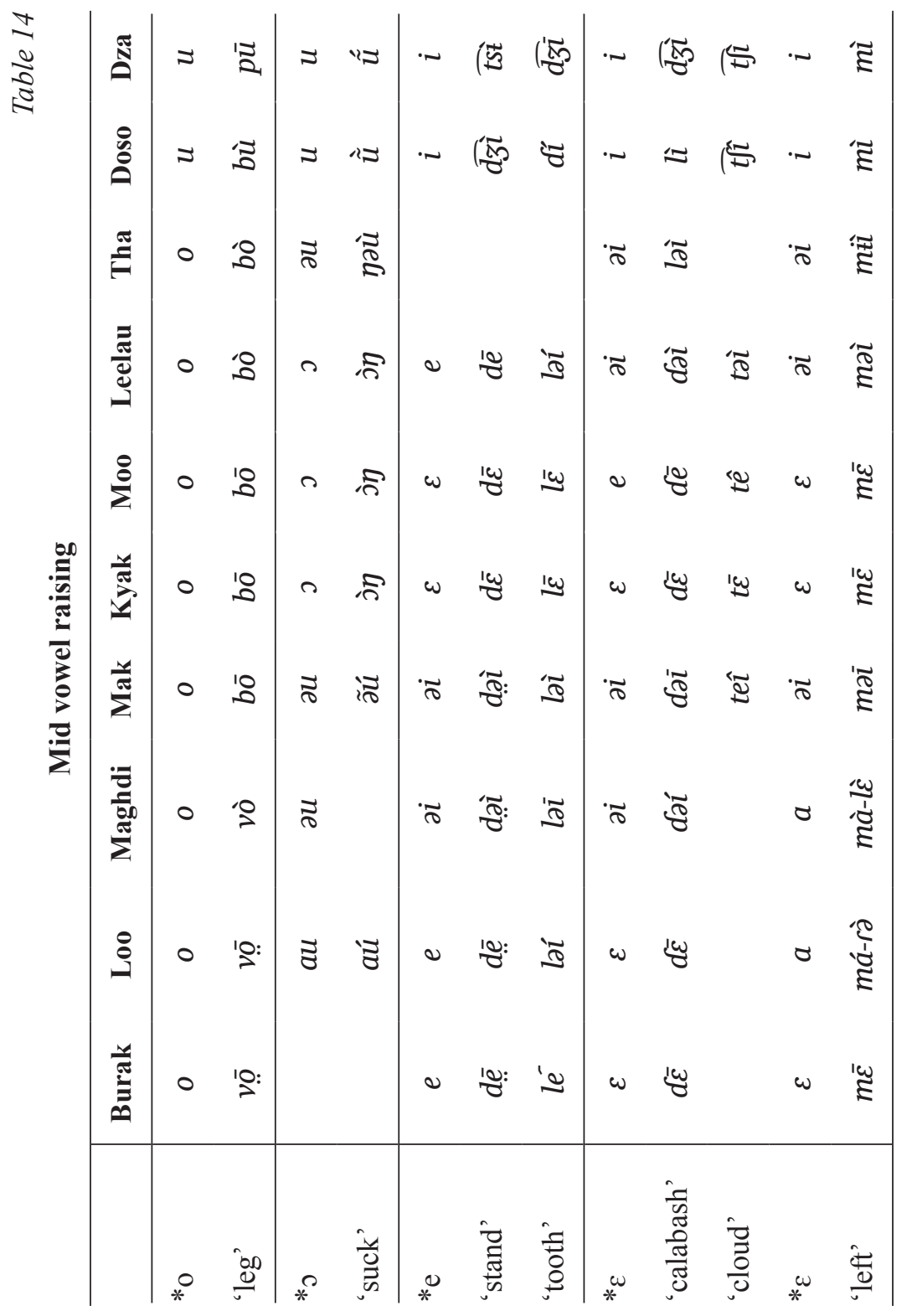


Table 15 shows other open syllable roots with a different process of back vowel diphthongisation ${ }^{*} u>w i,{ }^{*} o>w e$ in Doso-Dza. These are all after an alveolar consonant, therefore ${ }^{*} 0>$ we bleeds ${ }^{*} 0>u$ which is not found after alveolar consonants, unlike $* e, \mathcal{\varepsilon}>i$ which are found after alveolar consonants (Table 14). Back vowel diphthongisation is also implicated in an apparent derivation 'head' $\rightarrow$ 'on' in Burak-Loo.

Table 16 shows non-high front or back vowels in closed syllable roots. There are examples with *0 raising to [o] in Tha-Doso-Dza, but others are in widespread irregular correspondence with an on-gliding diphthong [wə]. Some similar variation occurs between $[\varepsilon]$, $[\mathrm{e}]$ and [jə] in the last six varieties of the second branch. Reconstruction of the on-gliding diphthong * $w$ ə is favoured by its wider distribution than [ग], by its apparent contrast with *0 in 'push' and 'basket', and because the reconstruction of *wa after more consonants than *ya matches the finding that many ${ }^{*} \mathrm{C} w$ structures are reconstructible whereas ${ }^{*} \mathrm{Cy}$ structures are rare $(\S 4.3)$.

\subsection{Nasalised vowels}

As already noted in 2.2 , nasalised vowels are largely confined to the second branch. Table 17 shows roots with nasalised vowels grouped as to whether they can be reconstructed or are innovations. In the first group ('bite,', 'scratch'), nasalised vowels correspond to oral vowels in the first branch, providing limited evidence of original nasalised vowels * $\tilde{i}$, * $\tilde{a}$ whose nasalisation has been lost in the first branch. This also raises the possibility that lexical isoglosses of the second branch with nasalised vowels like $\widetilde{k p} \tilde{a}$ 'many' may also be original. In the second group of roots, however, nasalised vowels found in the second branch (or in Mak) are innovated, because they correlate with the loss of a following nasal consonant. This process is lexically gradual, where the oldest example ('big') is inherited by all six varieties of the second branch, and the youngest examples have been innovated in varieties of today, although some are of uncertain date due to lack of attestation of the root in our wordlists for other varieties. 


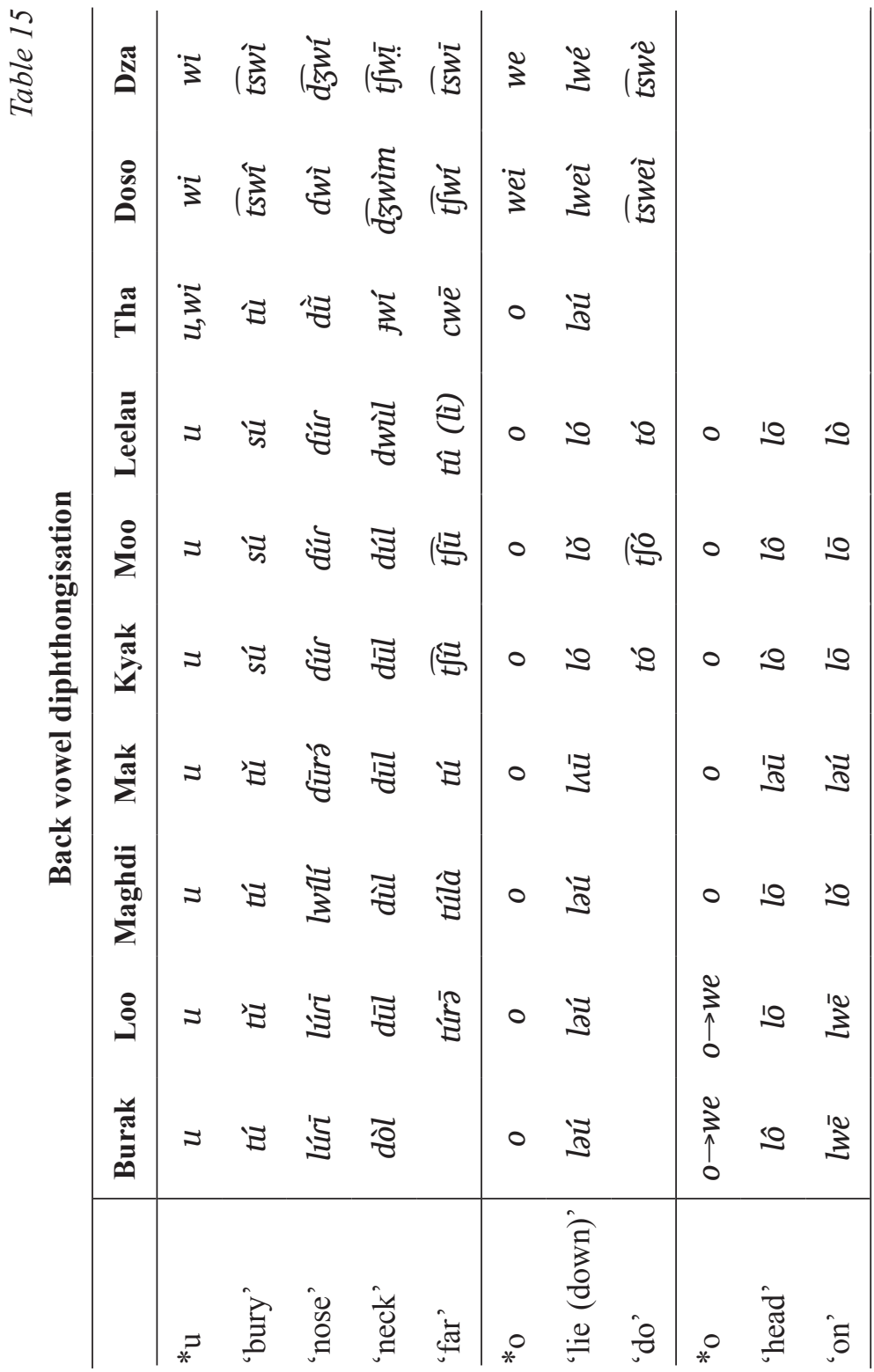




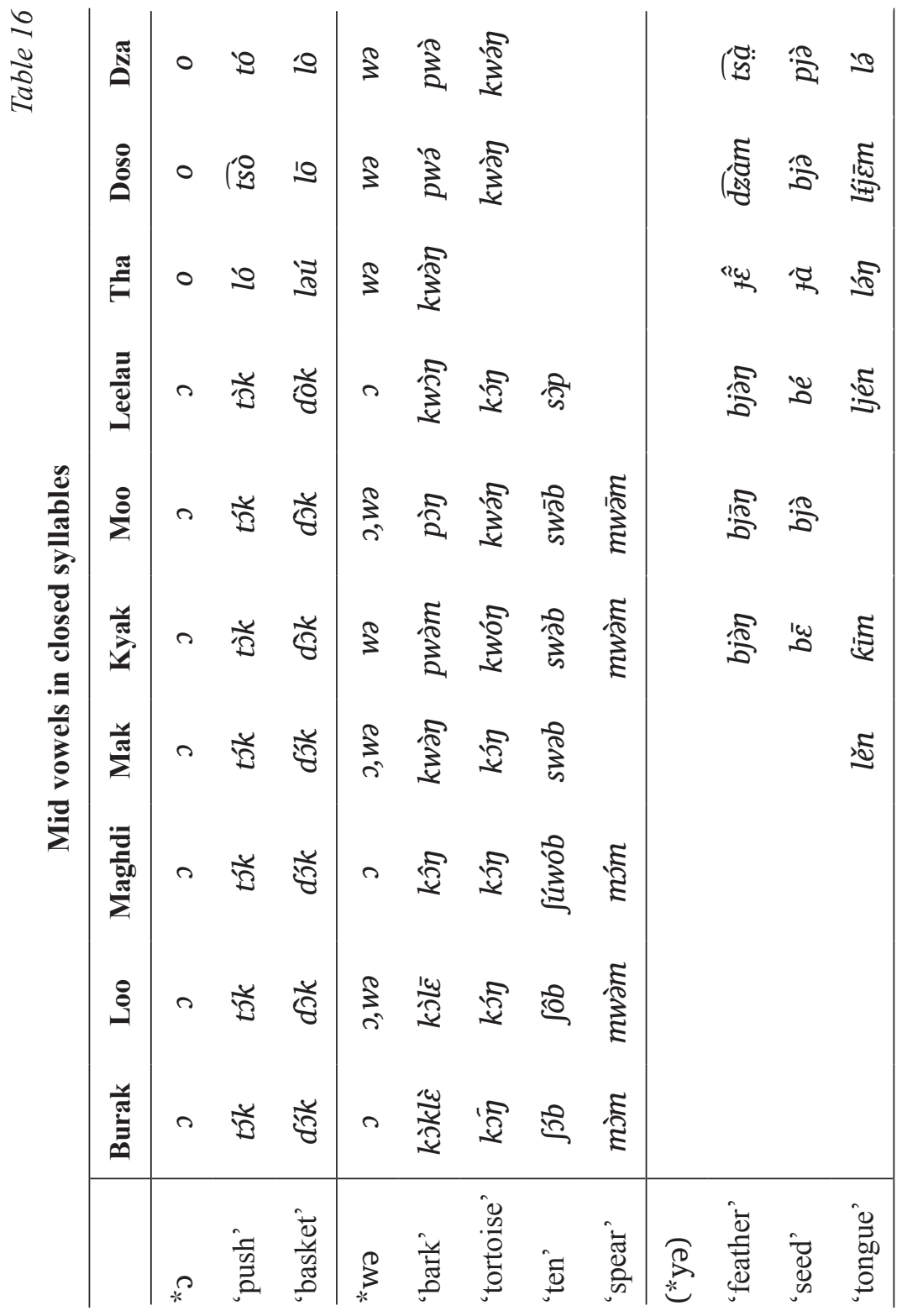




\begin{tabular}{|c|c|c|c|c|c|c|c|c|c|c|c|c|}
\hline \multirow{11}{*}{ 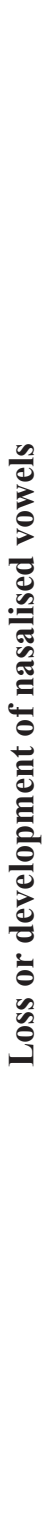 } & $\stackrel{\text { กี }}{\text { อี }}$ & 13 & 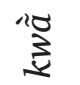 & "ত্ّ & "? & : & :ন & " & 'Zָ & (ర్ర: & 穴 & \\
\hline & ஜ & $\sqrt[3]{3}$ & & "ర్ర & ? & 沉 & הי & 宫占 & $\stackrel{\Sigma}{\xi}$ & ईే & 䠉 & \\
\hline & ฮ્ & & & 'ర్తి & "w & "వ్త & 胥 & : & & " & & 좀 \\
\hline & 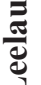 & ") & & "శ్ & 苣 & & ह & 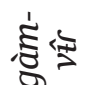 & '언 & 穴 & & \\
\hline & $\frac{8}{2}$ & 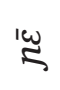 & & "ర్ & I্ঠ & & 穴 & S & (임 & 穴 & & \\
\hline & है & (3) & 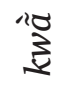 & '઼ָ & 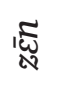 & & กิ & 㝑文 & 온 & 家 & "Iw & \\
\hline & $\frac{\mathscr{v}}{\Sigma}$ & 'స & & हे & 次 & סִ & 沵 & 占客 & 迩 & & & \\
\hline & 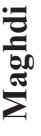 & ' & 'ర & న్ & 占 & 岕 & & & 次 & & & \\
\hline & $\stackrel{8}{\stackrel{\ominus}{\ominus}}$ & 次 & $\frac{\pi}{10}$ & & 馬 & : & 'Z̃ & 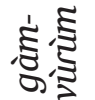 & 次 & & & \\
\hline & 气ี & & & & 经 & 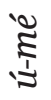 & & 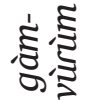 & 次 & & & 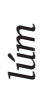 \\
\hline & $\frac{0}{60}$ & $\stackrel{\oplus}{\frac{0}{0}}$ & 总 & $\frac{600}{6}$ & 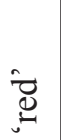 & 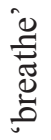 & $\frac{\tilde{y}}{0}$ & 离 & 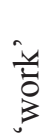 & & 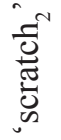 & $\stackrel{\oplus}{0}^{2}$ \\
\hline
\end{tabular}


Nasalised vowels have also developed from the loss of a preceding nasal. Table 18 shows nasalised vowel development in Doso-Dza accompanying change to root-initial palatal nasals. In the Dza form jấ 'meat', it looks as if nasalisation could be due to the loss of the final nasal as before, but the cognate Doso form yồ̀m (or jồm 'animal') which preserves the final nasal reveals that this is not so. Rather, the root-initial palatal nasal has changed to a new palatal consonant in Doso-Dza. Since this new consonant is voiceless, it cannot be produced with nasality, but the nasality is preserved on the following vowel instead. ${ }^{8}$

Table 18

\section{Development of nasalised vowel with [j]}

\begin{tabular}{|c|c|c|c|c|c|c|c|c|c|c|}
\hline & & $\stackrel{8}{\circ}$ & $\begin{array}{l}: \bar{z} \\
\bar{E} \\
\bar{E} \\
\sum\end{array}$ & $\sum_{\Sigma}^{\frac{\Lambda}{J}}$ & $\frac{n}{\sqrt{n}}$ & $\stackrel{8}{\Sigma}$ & 芯 & $\stackrel{\pi}{E}$ & 产 & $\stackrel{\widetilde{N}}{\mathrm{E}}$ \\
\hline $\begin{array}{l}\text { 'meat' } \\
\text { 'bad' }\end{array}$ & nâm & nám & nám & ла̀m & nă & пวัm & nám & $\begin{array}{l}\text { nè } \\
\text { náw }\end{array}$ & 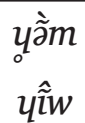 & jấ \\
\hline
\end{tabular}

Table 19 shows that vowel nasalisation also occurred upon loss of preceding nasals intervocalically in Tha-Doso-Dza, although one of the occurrences is attested in Kyak as well.

\subsection{Tone}

High, mid, low, falling and rising tones were noted. Table 20 presents some roots with fairly consistent tone. High and low tones are switched in Doso, except that $\mathrm{H}$ does not become $\mathrm{L}$ after a voiced

${ }^{8}$ The development of [j] through $* n V>j \tilde{V}$ tends to imply that [j] occurs before nasalised vowels in Doso-Dza. Dza jìำ 'fish' is an exception, where [j] realises initial *s, but no other exceptions are found either in this wordlist or over a larger data set of 2600 Dza words (Othaniel 2016). Some other roots in the Appendix 'brother, sister', 'good', 'red' show more comprehensive change $\mathrm{nVN}>\mathrm{C} \tilde{\mathrm{V}}$ in which the nasalised vowel could be derived from loss of either the preceding or the following nasal. 
Table 19

Nasalisation with loss of intervocalic nasal $\left(\mathrm{CV}_{1} \mathbf{N V}_{2}>\mathbf{C} \tilde{\mathbf{V}}_{2}\right)$

\begin{tabular}{|c|c|c|c|c|c|c|c|c|c|c|}
\hline$\frac{\hbar}{0}$ & 总 & $\stackrel{8}{8}$ & 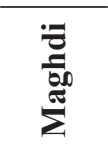 & $\sum^{\frac{N}{\omega}}$ & 尝 & $\stackrel{\&}{\Sigma}$ & 莺 & $\stackrel{\pi}{=}$ & 䓂 & ลี \\
\hline 'cold' & támá & tàmā & támā & támá & tém & tém & tém $\theta a ́$ & $t t$ & $t \overline{\tilde{a}}$ & tấ \\
\hline $\begin{array}{l}\text { 'red sldr. } \\
\text { ants' }\end{array}$ & tù̀c̀ & $(\bar{t} \tilde{t} w \bar{a})$ & $\left(\int \mathfrak{j} b \bar{b}\right)$ & (zwò) & $s \tilde{\tilde{a}}$ & zígzēn & Oíyà & $\theta \theta \tilde{a}$ & $s \tilde{\tilde{a}}$ & $s \hat{\tilde{a}}$ \\
\hline
\end{tabular}

obstruent. There is also some evidence of a mid tone level. Many roots, however, are more inconsistent in their tone across varieties. For now, we decline to reconstruct tone for items where tone is too inconsistent to be matched to the series below. We speculate that inconsistent tone may be the result of underlying tone sequences on monovocalic roots, as well as roots that have been reclassified for tone in some of the varieties.

\subsection{Breathy voice}

Vowels with breathy voice also occur. These are found sporadically, and always correspond to modal vowels of the same quality in other varieties. Table 21 shows some examples after nasal consonants.

Table 22 shows breathy voice after considerably less stable obstruent consonants. The consonant is usually voiced, except the *f in 'new', and in Dza where the consonant devoices. This rules out the possibility that breathy voice is simply an enhanced variant of modal voice, instead implying that breathy voice is a distinct laryngeal feature found in both branches (especially but not exclusively in Burak-Loo and Doso-Dza). There is some correlation with tone, as breathiness never co-occurs with high tone, but it is not exclusive to either mid or low tone, as is especially clear in Dza. The breathy feature repeatedly co-occurs with reduction of obstruents, including devoicing (or debuccalisation of $* \mathrm{f}$ ) in Dza in the first group of roots in Table 22, and development of the voiceless labial-palatal $\left[\tau_{b}\right]$ in Doso-Dza in the second group of roots. 


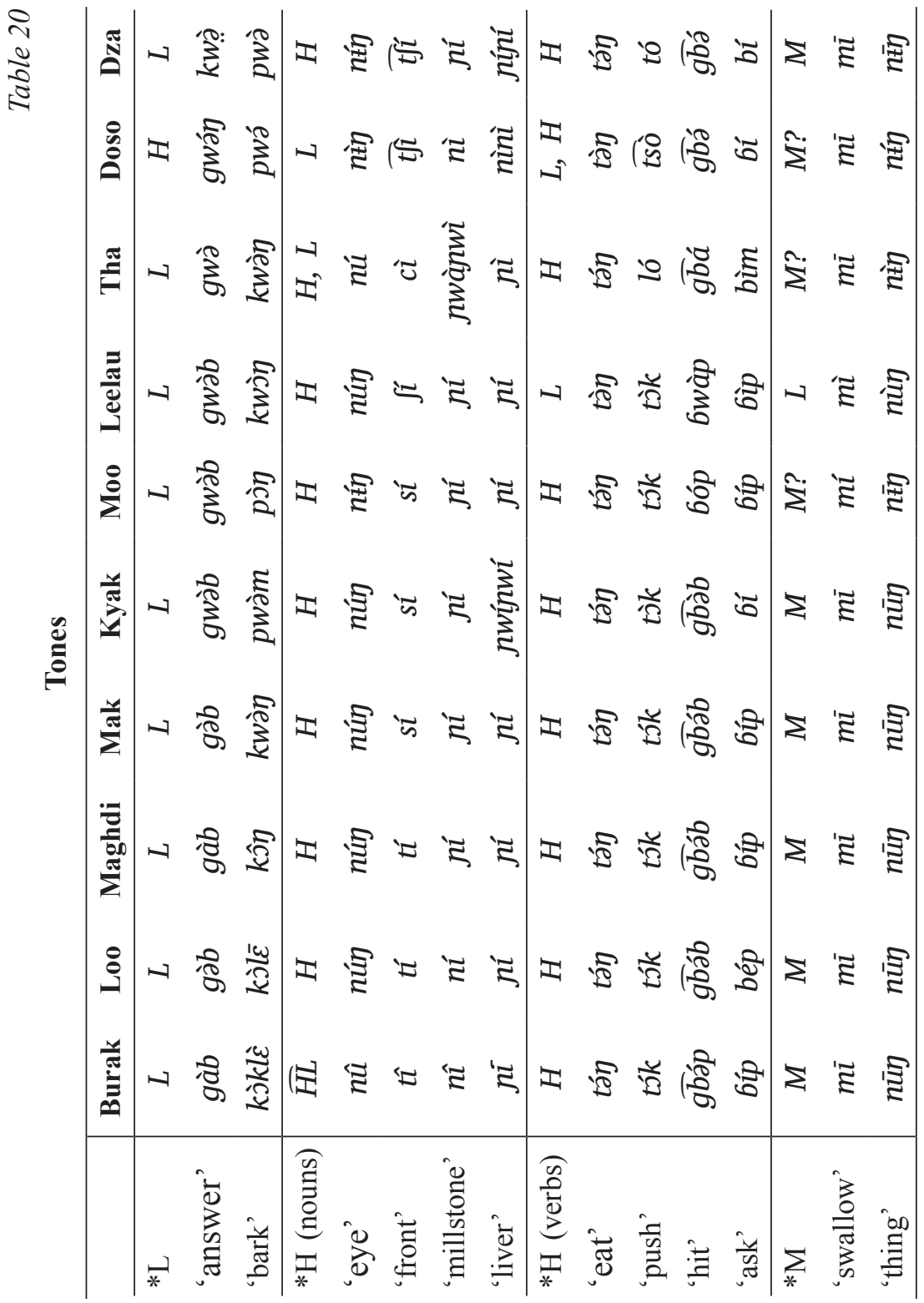


Table 21

\section{Breathy vowels}

\begin{tabular}{|c|c|c|c|c|c|c|c|c|c|c|}
\hline $\begin{array}{l}\frac{n}{0} \\
\frac{0}{60}\end{array}$ & 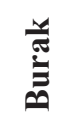 & $\stackrel{8}{9}$ & 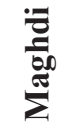 & 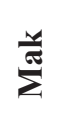 & 㫄 & $\stackrel{\Leftrightarrow}{\Sigma}$ & 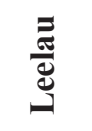 & 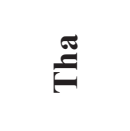 & $\stackrel{\circ}{\ddot{\theta}}$ & $\stackrel{\mathbb{N}}{\Omega}$ \\
\hline 'rain' & $m \bar{\varepsilon}$ & $m \bar{\varepsilon}$ & $m a \grave{i}$ & $m i \grave{t}$ & $m \bar{u}$ & múp & mùy & mínniló & mìn & mín \\
\hline 'hand' & $n \hat{a}$ & $n \overline{a ̣}:$ & $n \bar{a}$ & $n \bar{a}:$ & ná & ná & ná & nà & $n \hat{a}$ & $n \bar{a}:$ \\
\hline 'four' & $n \overline{c ̧ ̣ t ~}$ & $n \bar{e}: t$ & nàr & $n \bar{e} t$ & $n \bar{\varepsilon}$ & $n \hat{\varepsilon}$ & nà̀ & nànà & nánà & n’̀ \\
\hline
\end{tabular}

The data suggests, albeit not conclusively, that breathy voice may be a conditioning factor behind changes in obstruents (see also §4.1). ${ }^{9}$

\section{Consonants}

Jen languages are rich in consonants and in sound changes to consonants, with the following sounds reconstructed. Palatal * $n$ and velar $* \eta$ are in complementary distribution, so no phonemic distinction is made between them in the chart.

Table 23

\section{Proto-Jen consonants}

\begin{tabular}{|c|c|c|c|c|c|c|}
\hline & labial & alveolar & postalveolar & velar & labio-velar & glottal \\
\hline plosives & $* \mathrm{p} * \mathrm{~b}$ & $* t * d$ & $* \mathrm{c}$ & $* \mathrm{k} * \mathrm{~g}$ & $(* \widehat{\mathrm{kp}}) * \widehat{\mathrm{gb}}$ & \\
\hline affricates & & $* \widetilde{\mathrm{ts}} * \overline{\mathrm{dz}}$ & $* \overline{\mathrm{t} \int} * \overline{\mathrm{d}} \mathrm{z}$ & & & \\
\hline fricatives & $* \mathrm{f} * \mathrm{v}$ & ${ }^{*} \mathrm{~s} * \mathrm{z}$ & $* \int$ & & & $(* h)$ \\
\hline nasals & $* \mathrm{~m}$ & $* \mathrm{n}$ & *n & & & \\
\hline implosives & $* 6$ & $* d$ & & & & \\
\hline trill & & $* r$ & & & & \\
\hline $\begin{array}{l}\text { approxi- } \\
\text { mants }\end{array}$ & & $* 1$ & ${ }^{*} \mathrm{y} * \mathrm{U}$ & & ${ }^{*} \mathrm{w}$ & \\
\hline
\end{tabular}

${ }^{9} \mathrm{~A}$ related question for further research is whether breathy voice is properly associated with the vowel or with the entire root (which includes the affected initial consonant) in each variety. 


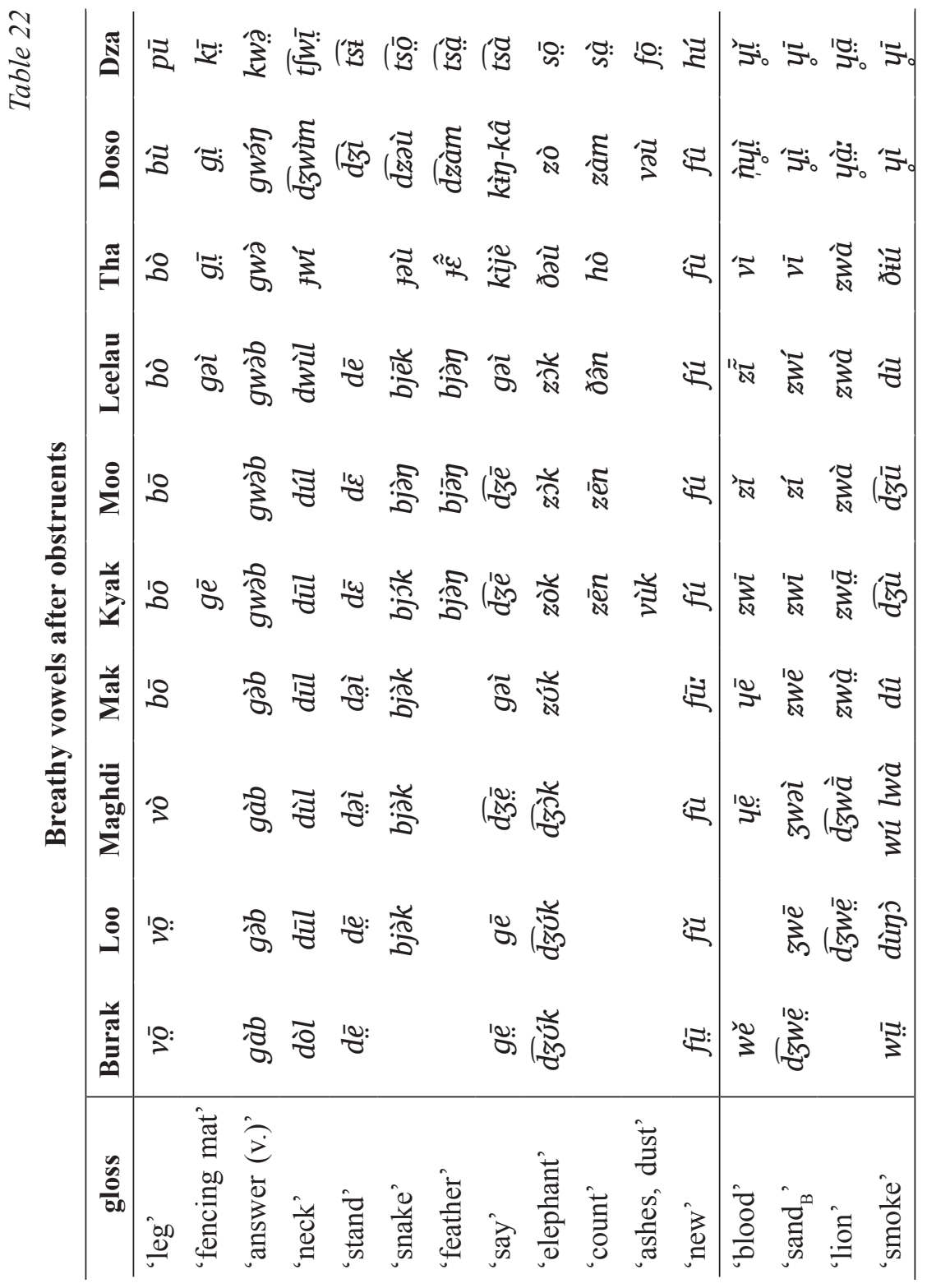




\subsection{Root-initial consonants}

Root-initial consonants are presented here grouped by manner of articulation. Table 24 shows voiceless plosives. The labial ${ }^{*} p$ splits to [p] and [f] in the second branch according to the following vowel, as retained in Maghdi, and with some spirantisation to [f] borrowed into Mak. However, *t and *k occur in fully stable examples. A palatal *c is evident in some incomplete series, contrasting with affricates listed in later tables. Labial-velar * ${ }^{k p}$ is poorly attested in just one root of the second primary branch (assumed borrowed into Mak, as argued in $\S 3.3)$.

Table 25 shows voiced plosives. These devoice in Dza, but with exceptions - perhaps because breathy voice is a precondition for devoicing (\$3.5), ${ }^{10}$ although this is not established across all the data. The labial $* b$ is assumed to have split in the first branch (the [v] fits better here than under $* v$, although this split is strangely contrary in its distribution from $* p>f$ in the second branch), but with Mak influenced by the $[\mathrm{b}]$ pronounciation of the second branch. The alveolar $* d$ develops affrication in Dza before high vowels, [ [3] before [i], or $[\overline{\mathrm{dz}}]$ otherwise, as also seen in more data from deimploded $* d$ below. The labial-velar $* \overline{g b}$ develops implosivity in Kyak-Moo-Leelau (Harley (2020) has $[\widehat{\mathrm{g}} \overline{\mathrm{b}}]$ in Kyak).

Table 26 shows three root-initial nasals $* m$, *n, *n, with other sounds developing from $* n$. Contrast between palatal $* n$ and alveolar ${ }^{*} n$ is weak for lack of $* n$ before front vowels or ${ }^{*} n$ before back vowels. However, $* n$ is in complementary distribution with root-final ${ }^{*} \eta(\S 4.2)$ and also realised as [y] word-initially before [w] in both Kyak-MooLeelau and Doso-Dza. Therefore, instances of $* n$ in the Jen language cluster may ultimately derive from either ** $n$ or $* * \eta y$ at higher levels of reconstruction.

${ }^{10}$ We are grateful to Mark van de Velde and Matthew Harley for this suggestion. 


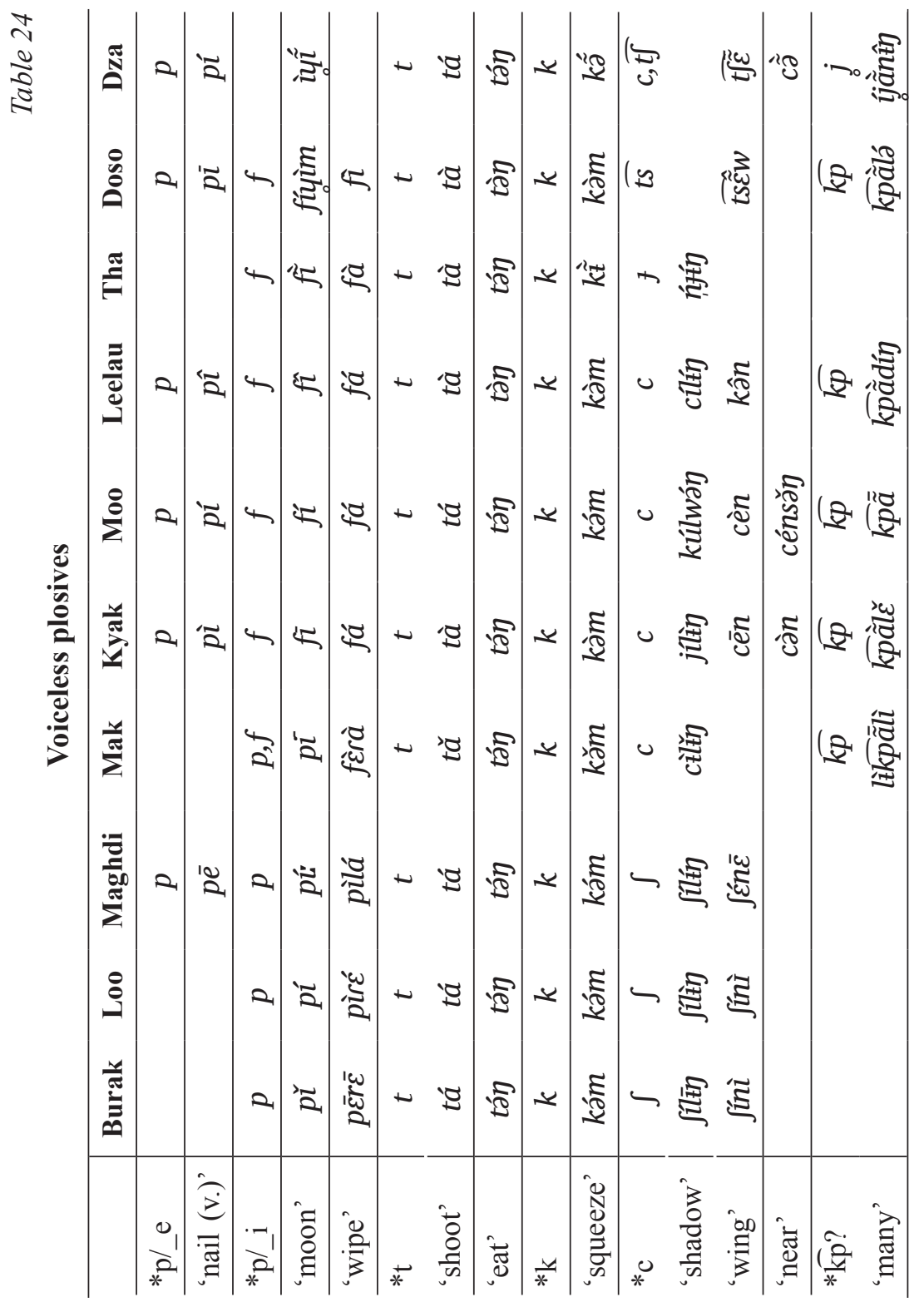




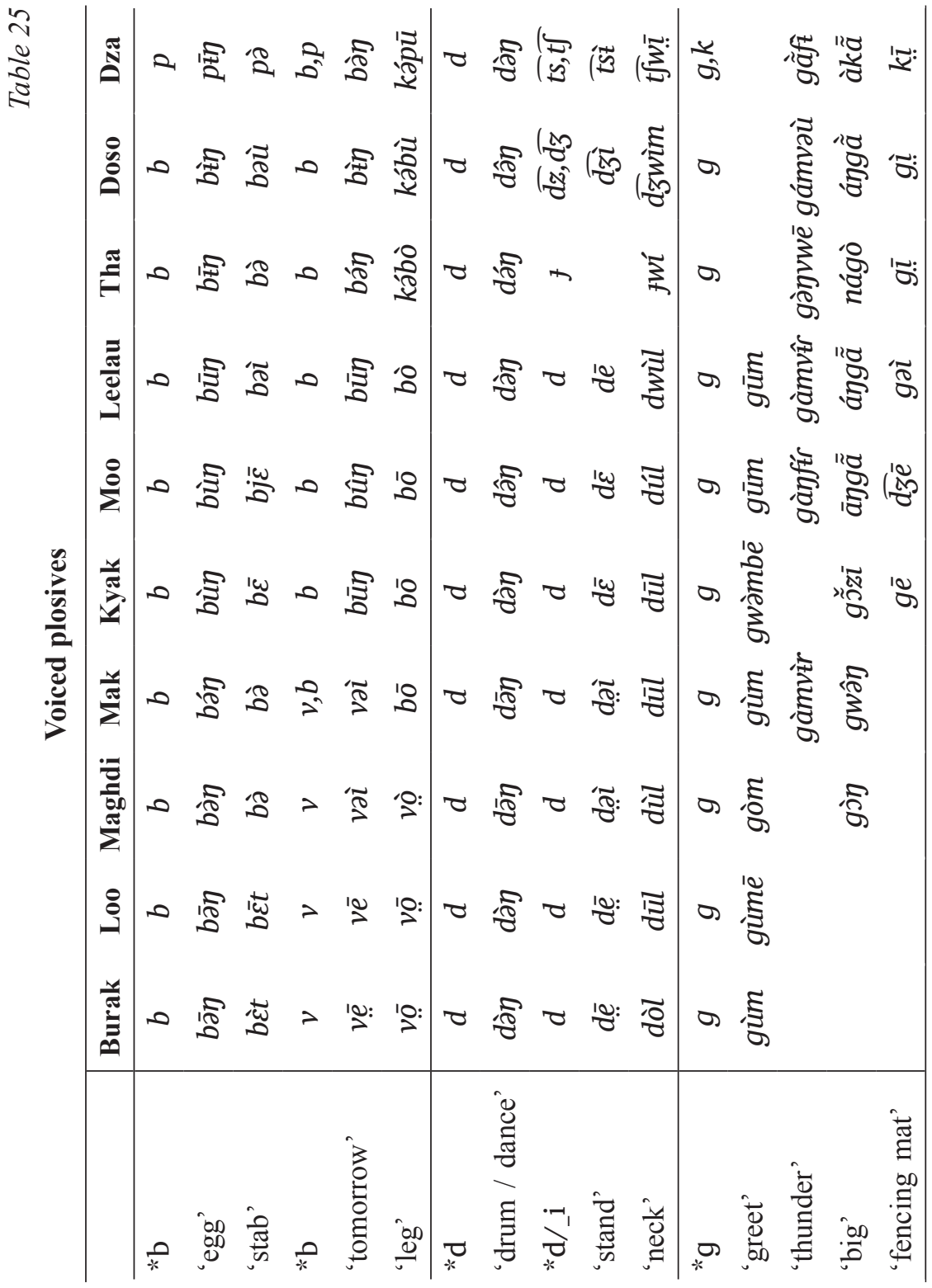




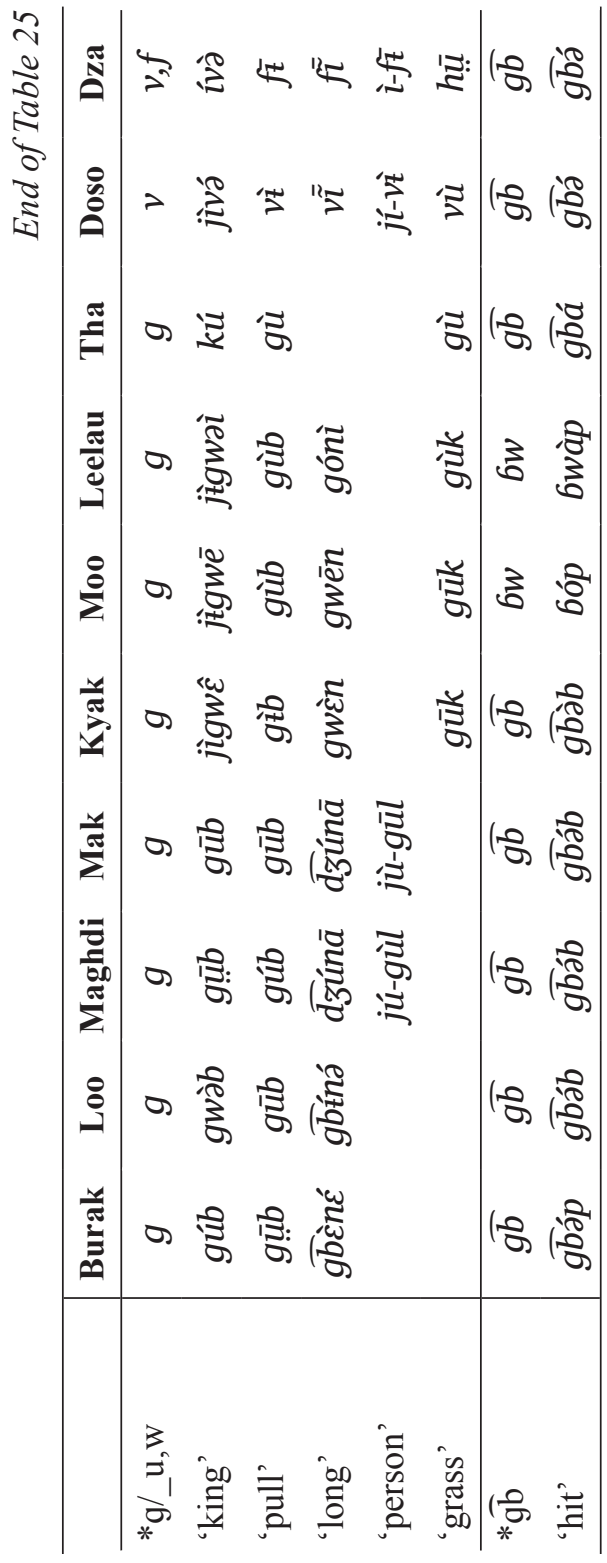


$\frac{2}{2}$

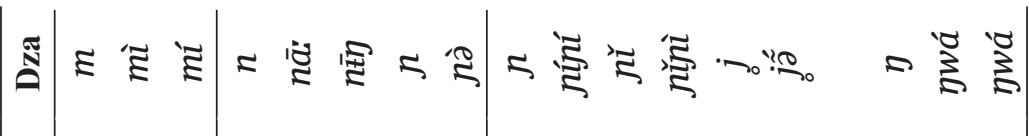

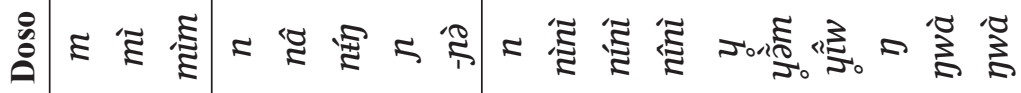

$$
\begin{aligned}
& \text { 吾 }
\end{aligned}
$$

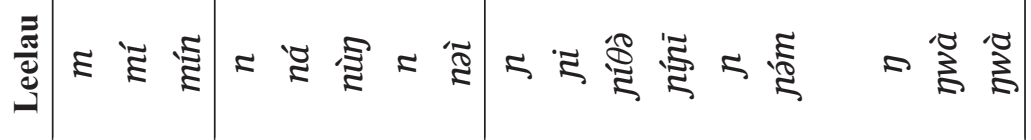

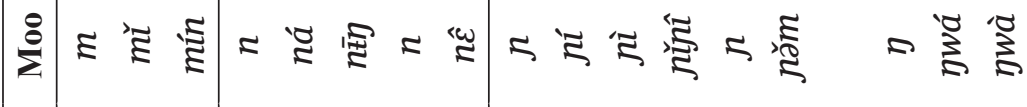

$$
\begin{aligned}
& \text { 岁 }
\end{aligned}
$$

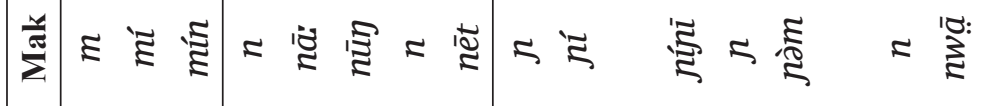

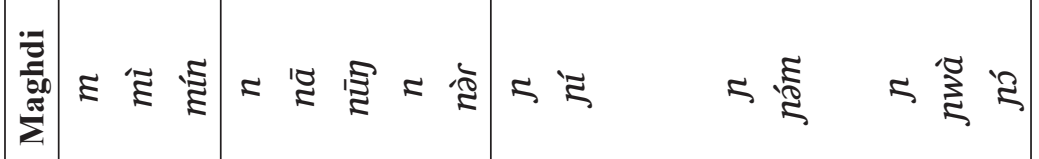

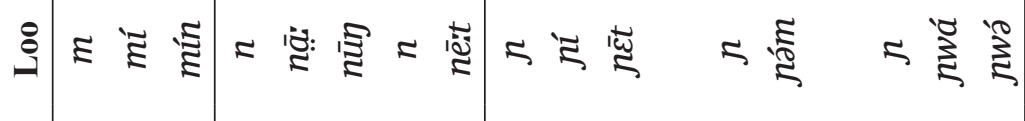

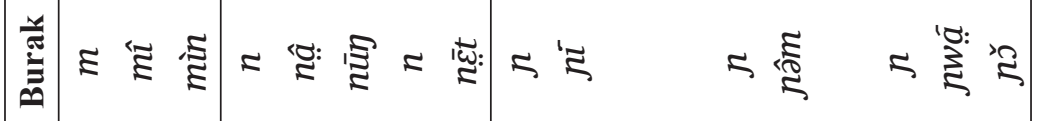

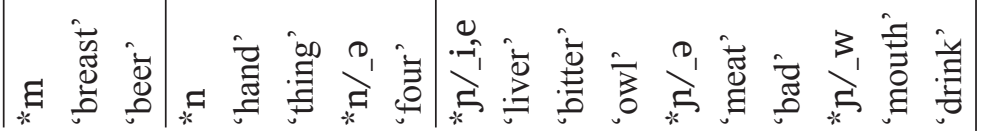


Table 27 shows three approximant series * $w$, * $u$, *y reconstructed from incomplete examples. As in all our comparative data, the palatal approximant is transcribed using the standard IPA symbol [j], but in reconstruction the symbol * $y$ has been used to support integration into Africanist scholarship. The labial-palatal * $y$ merges with * $\mathrm{w}$ in both BurakLoo and Kyak-Moo-Leelau, while the structure *yu becomes / $\mathrm{\varphi} \mathrm{i} /$ in several varieties, in effect these are further instances of $* u>$ wi (this includes *yo 'cook' affected by vowel raising * $0>u$ in Doso-Dza). In addition to these three approximants, voiceless approximants are also attested in Tha, Doso, and Dza, but these are innovations, found in other tables.

Table 28 shows two liquids $* l$, $* r$, but the only root containing an initial trill $\left({ }^{*} \mathrm{rab}\right)$ is lost in Tha and in Doso-Dza.

Table 29 shows intervocalic liquids, where a more complete series can be drawn up for ${ }^{*} r$. The ${ }^{*} r$ appears intervocalically due to ${ }^{*} r V$ extensions that are always present in the first branch but only sporadically in the second branch. Dza is one of the varieties where the trill merges with the lateral, a process also found in Dza loanwords (Fulfulde màlórì $\rightarrow$ Dza màlólì 'rice'), despite Dza having trills in ideophones (Benson 2020).

Table 30 shows implosives, which occur except in Dza, where they reduce to plain plosives. Deimplosion in Dza is recent because elderly Dza speakers still use implosives (Othaniel 2016). This loss is not in imitation of Hausa because Hausa has implosives, suggesting instead attrition in younger speakers. The alveolar $* d$ is found in irregular correspondences with the lateral, implying a stem-initial consonant alternation of unknown function, so that * $d$ can only be reliably reconstructed in 'basket' and 'calabash' (plus 'dog' in Table 35). Like the *d series, deimploded $* d$ in Dza is affected by affrication to [ [3] before [i] or $[\overline{\mathrm{dz}}]$ before $[\mathrm{u}]$ or $[\mathrm{w}]$. In Tha, ${ }^{*} d$ reduces to [d] before $[\mathrm{u}]$, and to $[\mathrm{j}]$ otherwise, and deimplosion of $* 6$ also seems underway.

Table 31 shows further examples of the irregular $l \sim d$ alternation with instances of $[k]$ in our data for Kyak and Moo. These roots show greater variation in their form as a whole. The $[\mathrm{k}]$ nearly always occurs before [i], suggesting it may represent a phonologically conditioned 


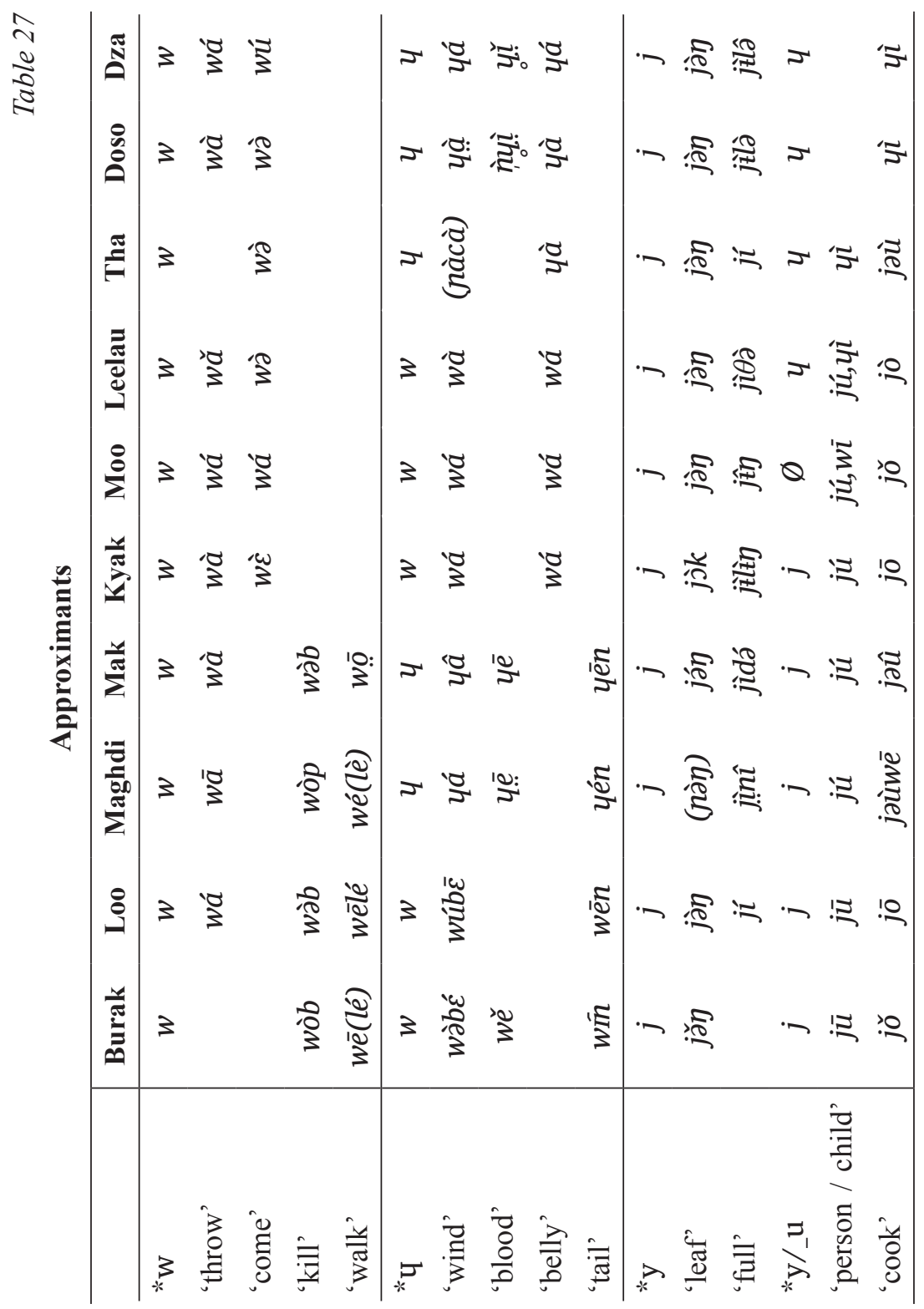




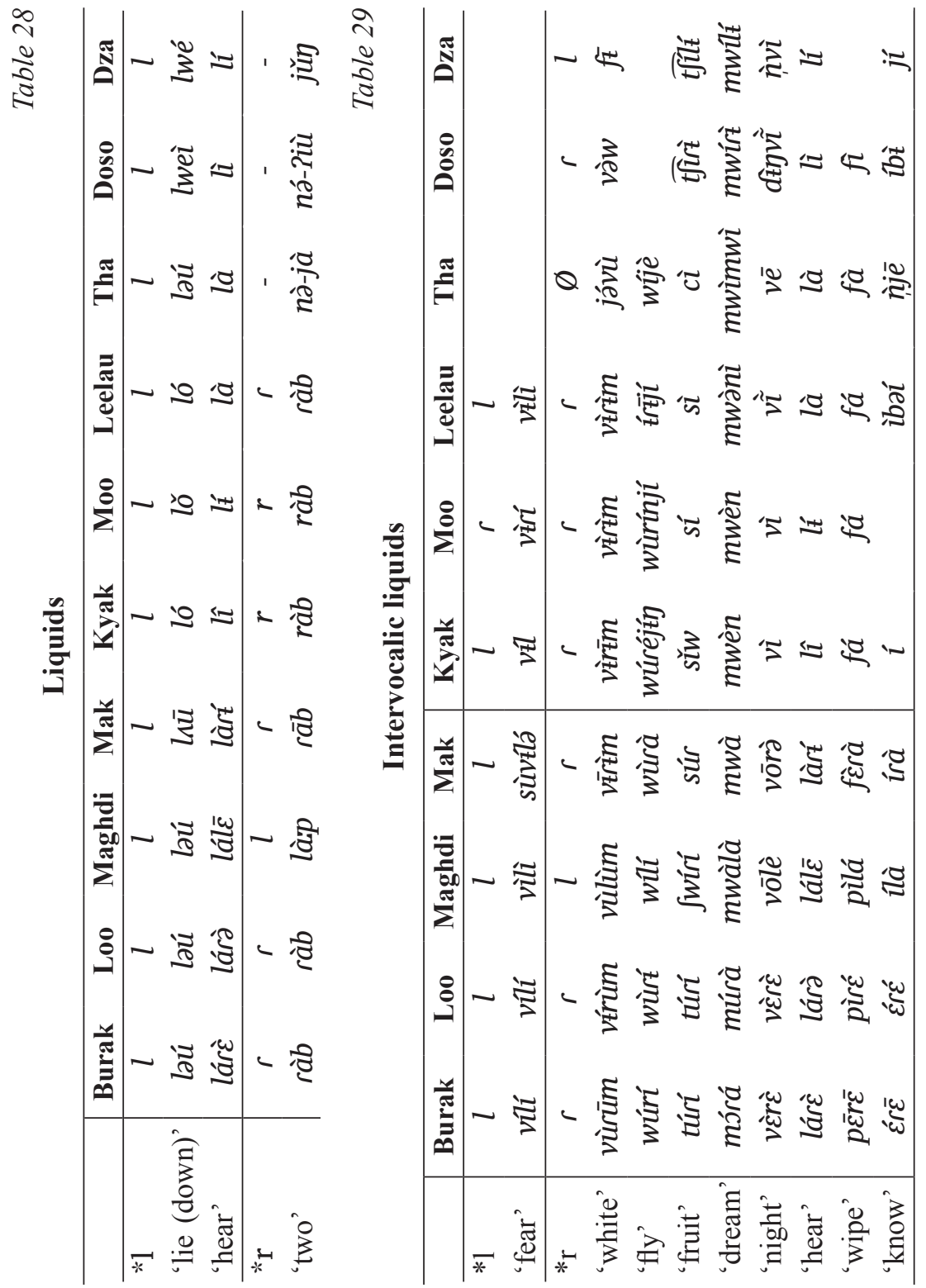


$\frac{2}{\frac{0}{0}}$

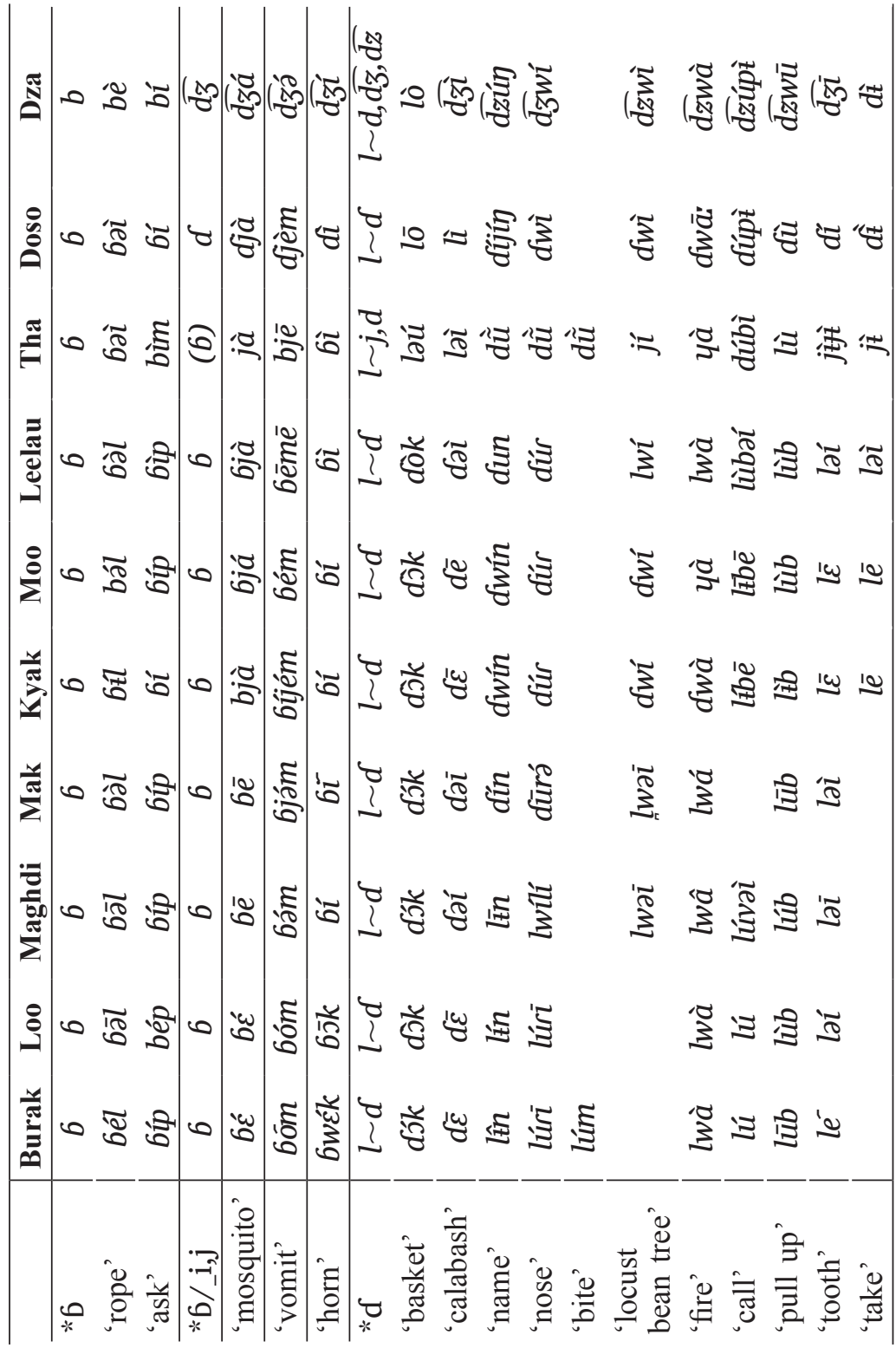


palatalisation of $[\mathrm{d}]$ to $[f]$ or $[\mathrm{c}]$, bearing in mind that other authors transcribe a palatalised implosive in Kyak [dyim] 'tongue' (Kleinewillinghöfer 1996, Harley 2020).

Table 32 shows fricatives in various unstable correspondence series. Devoicing is observed in Dza for $* v$ and $* z$ as seen already in voiced plosives, but again there are exceptions. There is a persistent problem of lack of attestations of * $s$ and $* z$ in the first branch, partly due to initial consonant alternations in verb stems (see Table 6 above). Postalveolars are distributed across both branches so are reconstructible; a limited contrast with alveolar is apparent in 'fish' vs. 'crocodile'. In Doso-Dza, *s, * $\int$ or *z become [h] with unclear conditioning environment, and [j] before non-low central vowels [i] or [ə], becoming [y] in Doso.

Table 33 presents affricates. Affricate series are complex with plosive, fricative and affricate correspondents. We find no conditioning by the following vowel that would derive affricate correspondents from the softening of plosives. Instead, the series partly resemble the relevant fricative series ${ }^{*} s$, $*$, * $\int$, and in some cases varieties of both branches attest frication, all supporting reconstruction of affrication. Alveolarpostalveolar contrast is preserved in various ways, but is also neutralised in various contexts. We attempt to explain different correspondence series for ${ }^{*} \overline{t s}$ and for ${ }^{*} \bar{t}$ in terms of following vowels, this too is complex because the vowels vary from variety to variety.

\subsection{Root-final consonants}

Table 34 presents the limited set of consonants that are reconstructible root-finally. These are nearly all conserved in the first seven varieties, but there is extensive loss in Tha, Doso and Dza (as parallel developments rather than shared innovation, given the survival of more final consonants into Doso). Only * $\eta$ is retained in all varieties. This is surprising, because * $y$ cannot be reconstructed root-initially, although it is in complementary distribution with root-initial $* n(\$ 4.1)$. Root-final $* r$ is only supported from varieties of the second primary branch plus Mak.

Various interactions of the final consonant with the preceding vowel are also evident in Table 34. Sonorants $* n$, $* \eta$, *l reduce to [m] in Doso after 


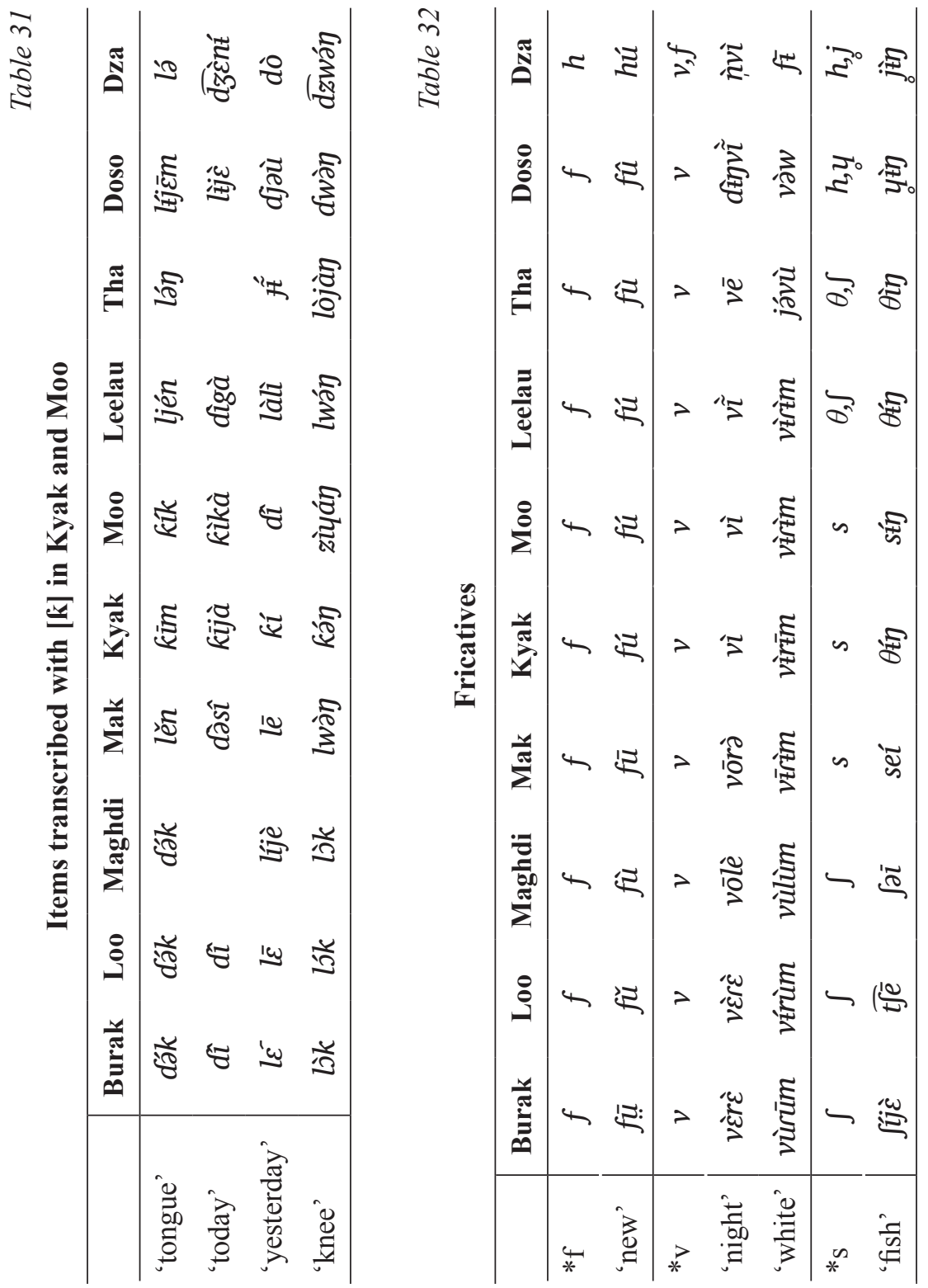




\begin{tabular}{|c|c|c|c|c|c|c|c|c|c|c|c|c|}
\hline อับ & $\stackrel{10}{\Sigma}$ & 지 & 5 & 洲 & is & 'О్: & & 'ర్వ: & త్ర & '으 & : & ! $\stackrel{\omega}{\omega}_{0}$ \\
\hline $\begin{array}{l}\text { ஜ } \\
\text { ஜ } \\
\stackrel{0}{0}\end{array}$ & I0 & סָ & es & 岕 & $\frac{\vdots}{i}$ & 'ం & & క్రి & త్ర & 요 & ?חי & $?$ \\
\hline$\stackrel{\Xi}{E}$ & $\stackrel{\sim}{\sim}$ & 8 & es & 芯 & $\vdots$ & דיָ & & '류 & 'ర & '0 & S & "w \\
\hline 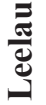 & $\underbrace{\Sigma}$ & 'ঠ & 0 & 今ి & to & กั & & 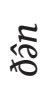 & 'ర & 炃 & 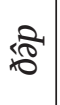 & 萿 \\
\hline$\frac{8}{8}$ & $\bar{\omega}$ & 'ర & es & 芯 & $\mathbb{N}$ & กี่ & & 憂 & 'ర్త & 'ָ & న్ని & న్ల \\
\hline 章 & $\dot{\omega}$ & sర & es & 占 & $\mathcal{N}$ & 灾 & & స్వ & ర & '૦人్ & న్ని & 1ీ్ట్ \\
\hline$\frac{y}{\Sigma}$ & 萝 & & es & $\widetilde{w^{\circ}}$ & 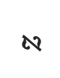 & : & $\sqrt{N}$ & & & & & \\
\hline 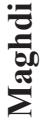 & $\underbrace{10}$ & & $\underbrace{\circ}$ & 迎 & $\frac{M}{\sigma}$ & 苚 & $\frac{\sqrt{0}}{\sigma}$ & & & & & \\
\hline ְ̊ & $\underbrace{i \pi}$ & & 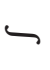 & 迎 & $\frac{n}{\sigma}$ & i⿱宀 & (స్ర & & & & & \\
\hline 光 & $\underbrace{\ll}$ & & $\underbrace{\prime}$ & 迎 & (1) & î̀ & & & & & & \\
\hline & $\frac{0}{3}$ & ֻี & $\breve{*}^{\circ}$ & 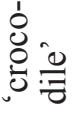 & $*^{N}$ & 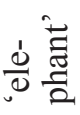 & 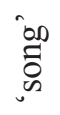 & 苂 & .0, & $\frac{V}{3}$ & $\bar{\Xi}$ & $\overbrace{0}$ \\
\hline
\end{tabular}




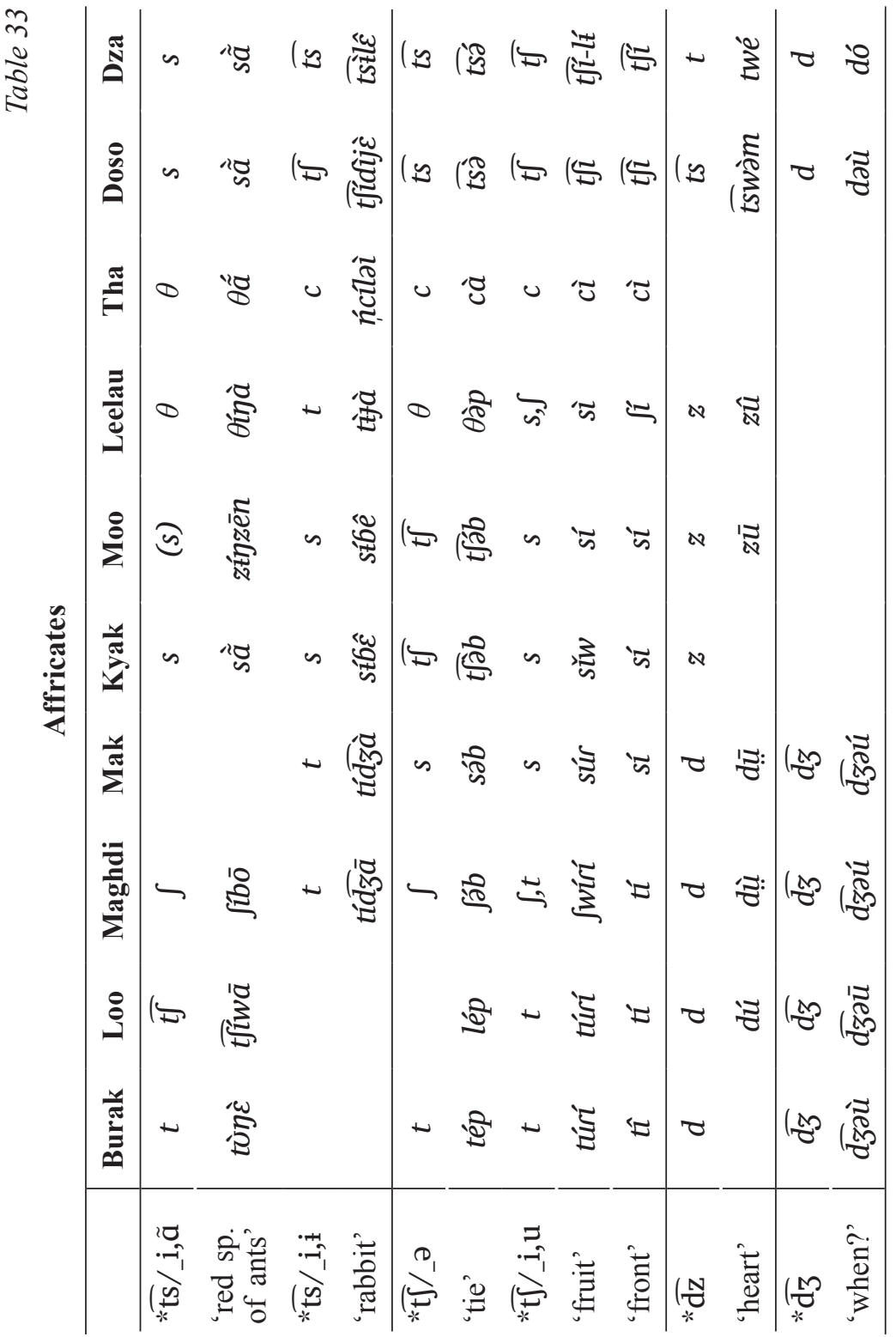


some (but not all) low tone vowels. There are observable co-occurrence patterns of ${ }^{*} k$ after ${ }^{*} o$, ${ }^{*} m$ after ${ }^{*}$, alveolar stops ${ }^{*} t$, " $n$ after front vowels, $* r$ after central vowels, and $* b, * \eta$, *l after either * $u$ or $*$. Vowel changes are also visible accompanying final consonant loss in Tha, Doso and Dza.

\subsection{Labialisation and palatalisation}

Palatal articulation can only be reconstructed after $* b$ as in Table 35 , although it appears sporadically with other consonants in the data. There is a shift to a full palatal [f] in Tha (or affricate in Doso-Dza).

Labial articulation is reconstructible after many more consonants. The root-initial consonant usually follows the series given above in $\S 4.1$, and the $[\mathrm{w}]$ is rarely lost, but may be vocalised before [i] as $* w i>u$, or before [ə] as ${ }^{*} w \partial>0$, and there are some other departures from this general pattern. Table 36 presents $* k w$ which is unstable in different ways in each root despite * $k$ itself being stable. For 'scratch', original * $k w$ allows hardening in the first branch to [p] where the opposite reconstruction is doubtful given the stability of * $p$ before [e] (Table 24), or in the second root with more intensive meaning, to [kp].

Table 37 presents labialised series in which labiodental fricatives and labial approximants emerge. The appearance of the labial-palatal [] in Tha indicates that it is functionally $/ \mathrm{jw} /$, so that the previously established change $* d>j$ recurs as $* d w>j w$. Likewise, its voiceless counterpart [u] develops in Doso-Dza from ${ }^{*} s w$ and ${ }^{*} z w$, hence it is functionally $/ \mathrm{jw} /$. The voiceless labial-velar $[M]$ develops in Dza in some series with single examples (also 'maize' in Table 34).

Tables 38 and 39 present labialised affricates that derive from different sources in different vowel contexts. Before [u] or [wə], affricates have plosive reflexes in the first branch, but we do not analyse this as development of affrication in the second branch, because the affricate series contrast with plain plosives *t, ${ }^{*} \mathrm{~d}$ and each other in this environment, and therefore will be reconstructed as affricates. The affricates with $[w]$ before front vowels in Table 39 are attempts to explain the contrasting series found there; these series may also be compared with affricates without $[\mathrm{w}]$ in Table 33. 


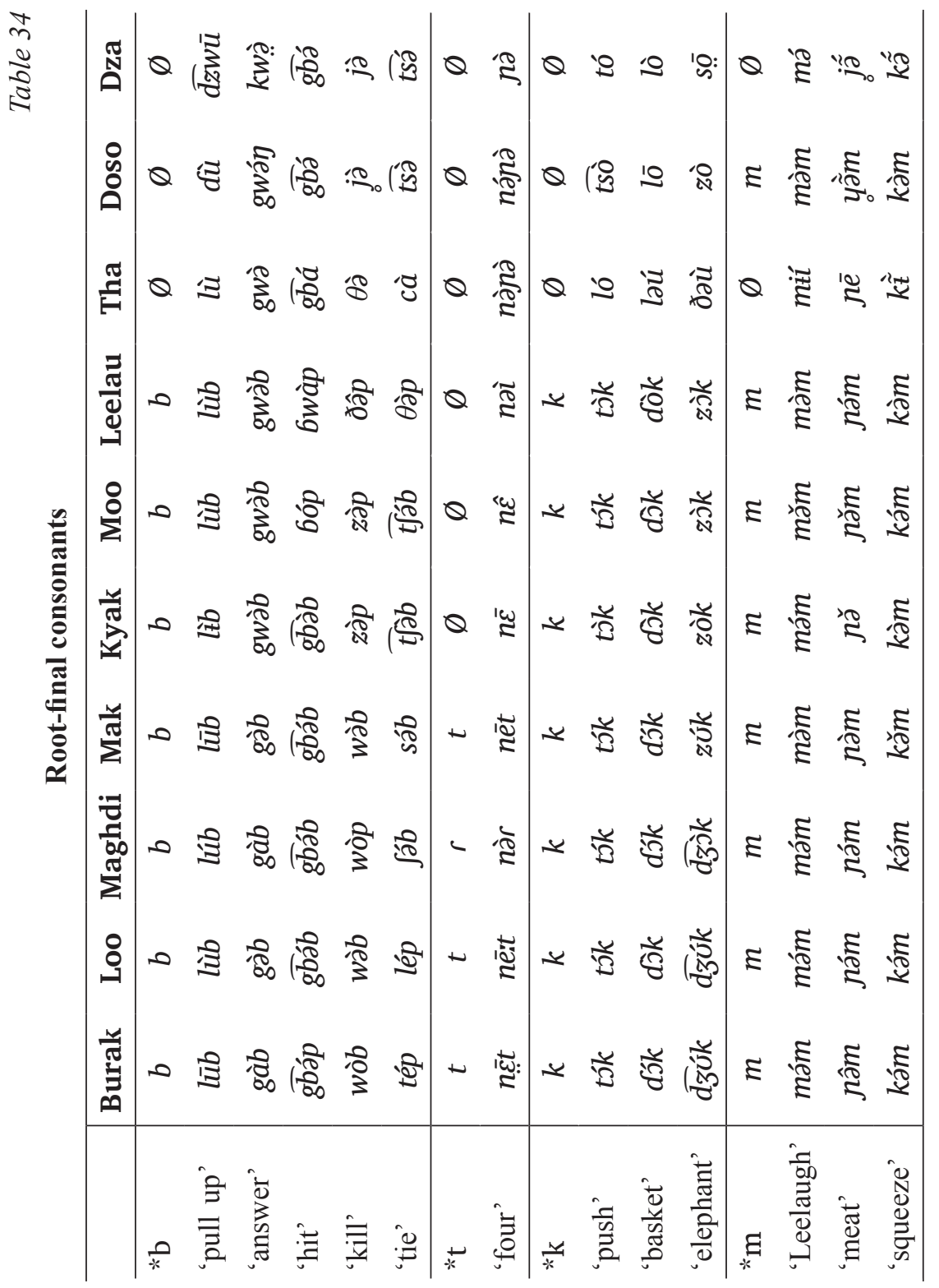




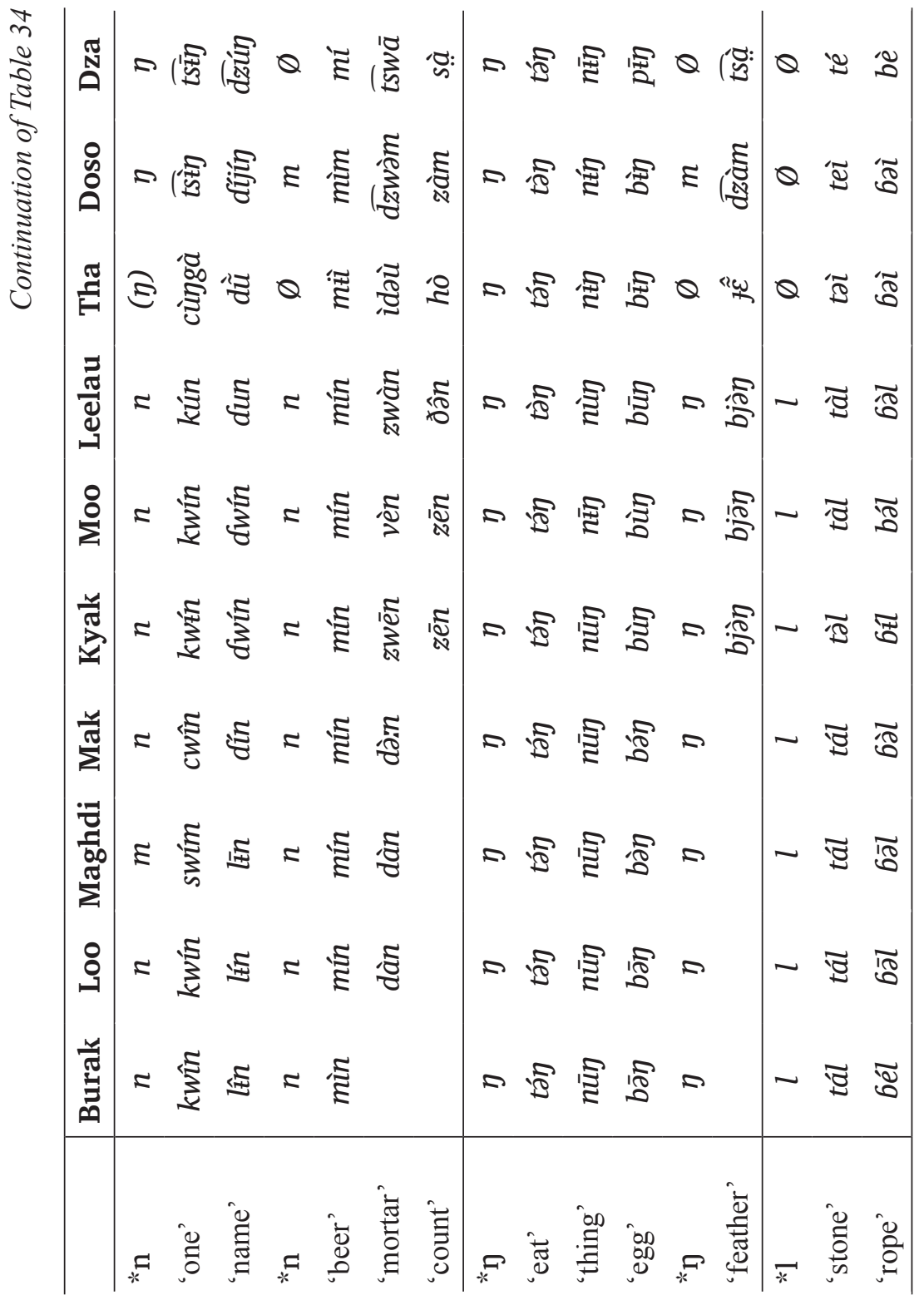




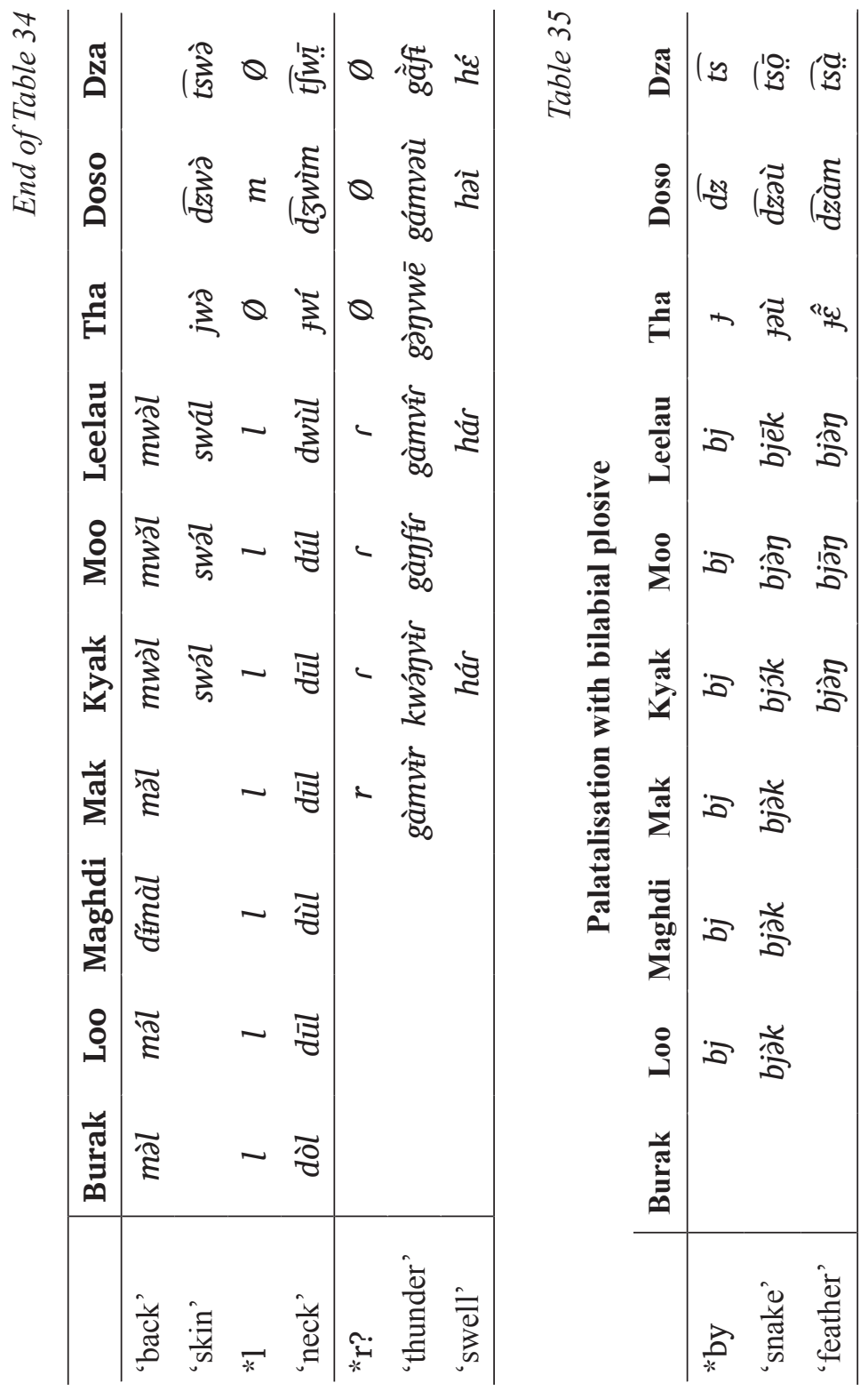




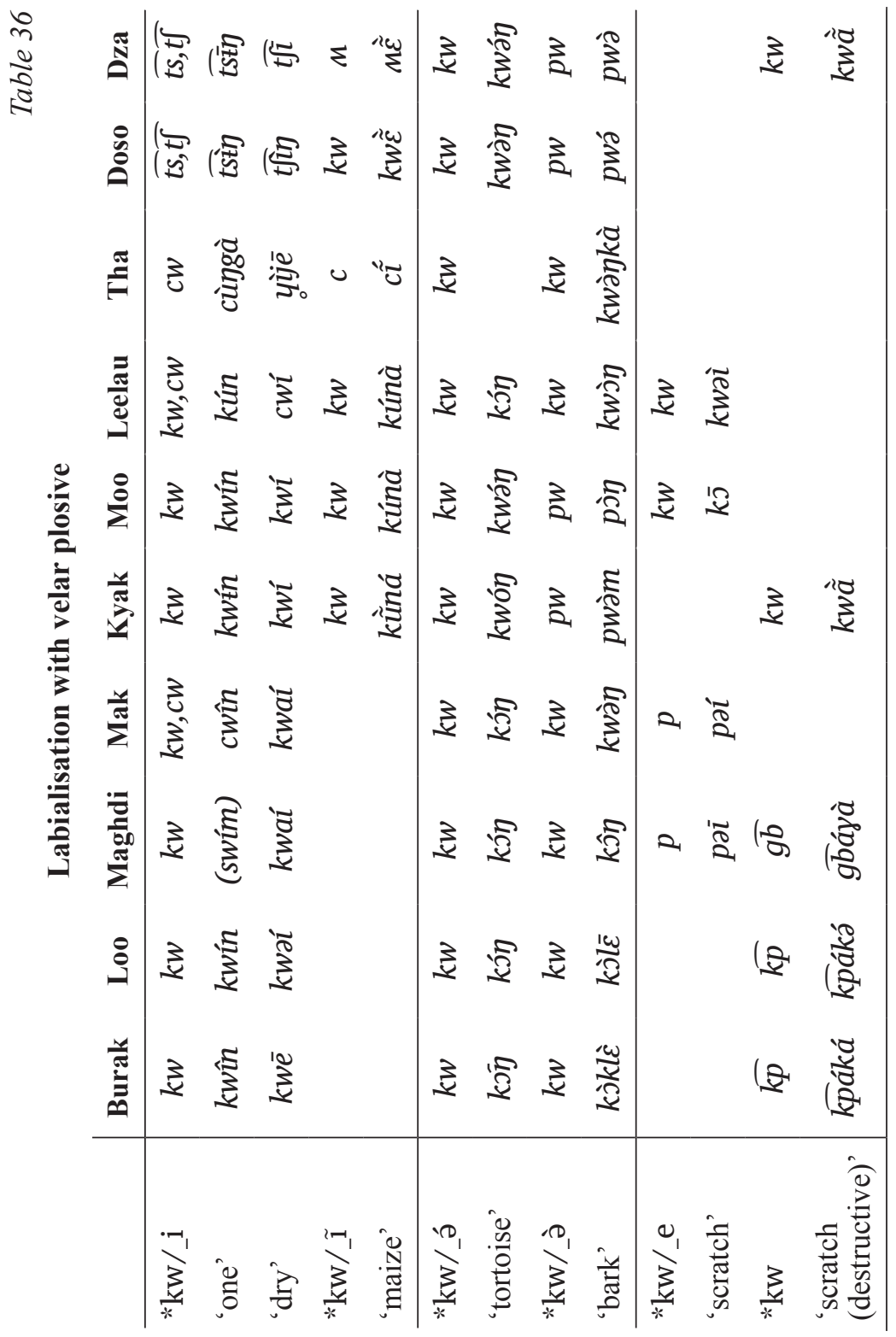




\begin{tabular}{|c|c|c|c|c|c|c|c|c|c|c|c|c|c|c|c|}
\hline \multirow{11}{*}{ 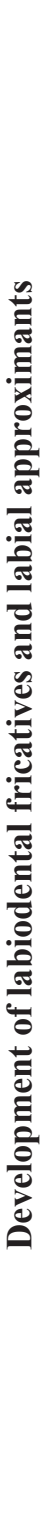 } & อั & 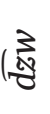 & (ত్ర & ) & $1 \infty$ & 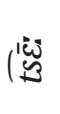 & ऐे & "र & $\underbrace{\underbrace{}_{0}}_{\text {న。 }}$ & న. & న。 & న. & ' & $\underbrace{3}_{2}$ & 'రి: \\
\hline & ஜ̂ & छे & 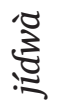 & 'ప & $\left(\frac{\pi}{8}\right.$ & $\left(\begin{array}{c}\tilde{\omega} \\
\tilde{\nabla}\end{array}\right.$ & & 25 & $\underbrace{3}_{\Omega_{0}}$ & ת. & నే & ని & $\frac{\sqrt{2}}{\frac{5}{2}}$ & $\underbrace{\overbrace{0}}_{\Omega_{0}}$ & 。: \\
\hline & $\stackrel{\underline{E}}{E}$ & $\underbrace{3}$ & 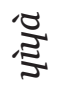 & ' & $\underbrace{3}_{2}$ & $\stackrel{1}{2}$ & & $"$ & $\stackrel{8}{*}$ & & $\stackrel{\nabla}{r}$ & $\underset{⿱ 乛}{\mathbb{2}}$ & "ס & उे & 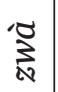 \\
\hline & $\frac{\vec{\pi}}{\mathbb{d}}$ & छे & ఏి & હે & ふे & $\sum_{\infty}^{2}$ & 4 & & के & ๙ิ & ’े & ऐे & ईే & ऐे & 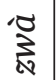 \\
\hline & $\frac{8}{2}$ & 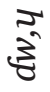 & క్ర & ' & ڤे & उ্ & & ir & $\hat{x}^{2}$ & 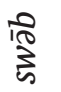 & 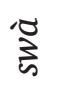 & 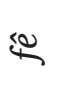 & $\frac{\pi}{\sqrt[1]{2}}$ & ऐे & 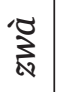 \\
\hline & $\frac{v}{\sqrt{*}}$ & छे & (ఫ) & కె & ふे & $\sum_{0}^{5}$ & & 4 & के & $\frac{\pi}{3}$ & $\stackrel{+\infty}{\grave{s}}$ & $\sum_{\bar{s}}^{\infty}$ & $\frac{\pi}{2}$ & ऐे & 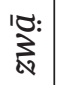 \\
\hline & $\stackrel{y}{\Sigma}$ & छे & ¿ & $\stackrel{Ð}{2}$ & $(\overrightarrow{\tilde{\sigma}}$ & 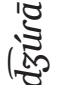 & ऐे & & मे & $\frac{i}{\infty}$ & ऐે & 's & & ते & 'ర: \\
\hline & 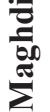 & छे & ఫે & 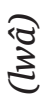 & $(\overrightarrow{\widetilde{\sigma}}$ & 点 & 3 & & 3 & :ి & $\underbrace{0}$ & 으 & & (ָे) & (ָ) \\
\hline & $\stackrel{8}{\varrho}$ & छे & 'ర & ᄅे & (0) & (⿻心㇒ & $(\underbrace{3}_{\stackrel{\Xi}{2}}$ & (ָ) & $\stackrel{3}{\stackrel{3}{E}}$ & :0ి & & & & (하 & 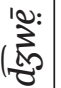 \\
\hline & صै & छे & ¿ & ప & 10 & $\overbrace{\infty}^{1 \omega}$ & 3 & క' & 3 & तิ & క & & & $\frac{\grave{\vec{b}}}{\vec{\sigma}}$ & \\
\hline & & $\underbrace{3}_{*}$ & 임 & 包 & $\sum_{*}^{3}$ & 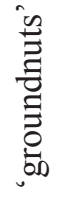 & 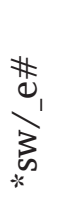 & 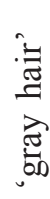 & 家 & 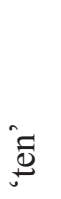 & $\overbrace{}^{\widetilde{\sigma}}$ & 胥 & 泀 & $\sum_{*}^{+}$ & $\stackrel{ }{\circ}$ \\
\hline
\end{tabular}




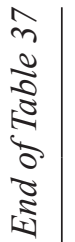
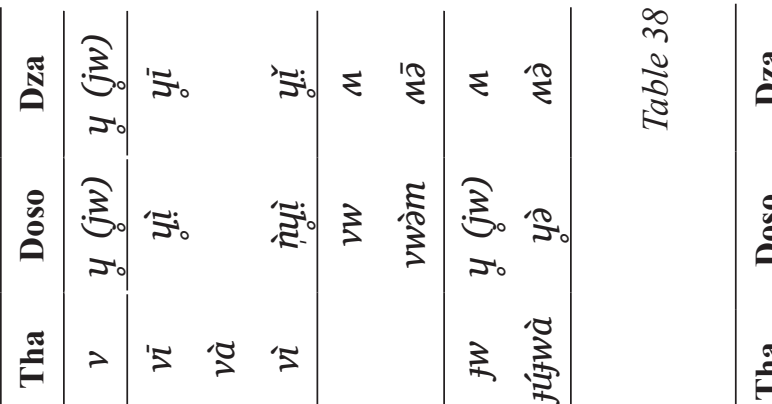

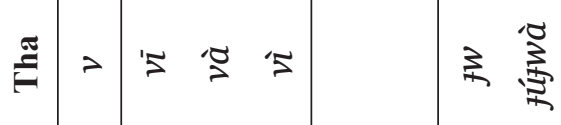

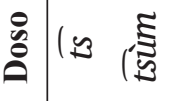

离

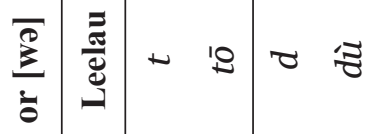

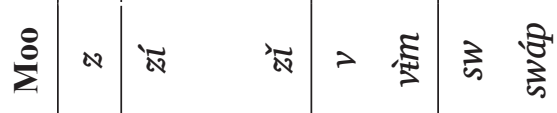

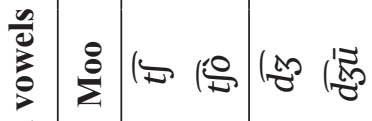

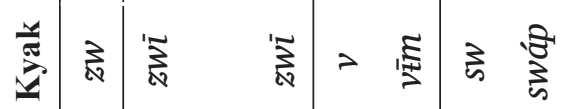

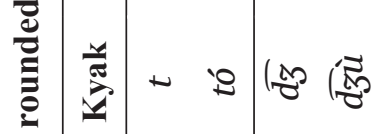

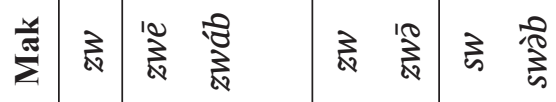

焉

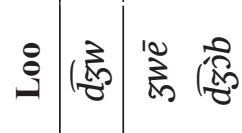

离

3 :

竞

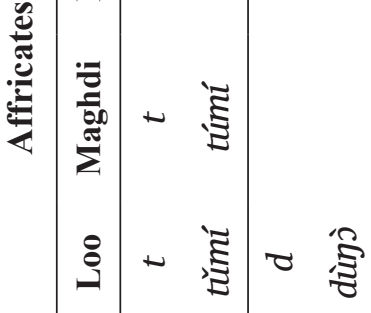

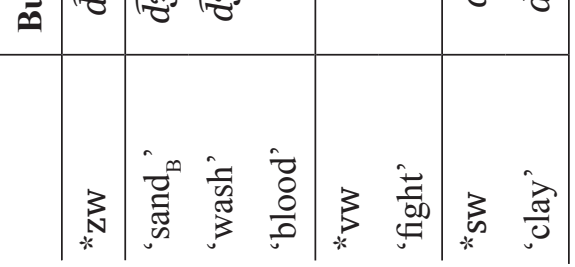

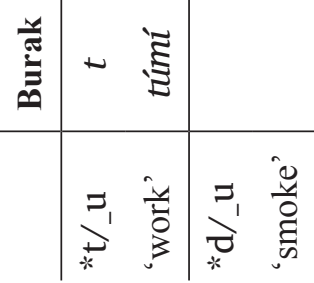




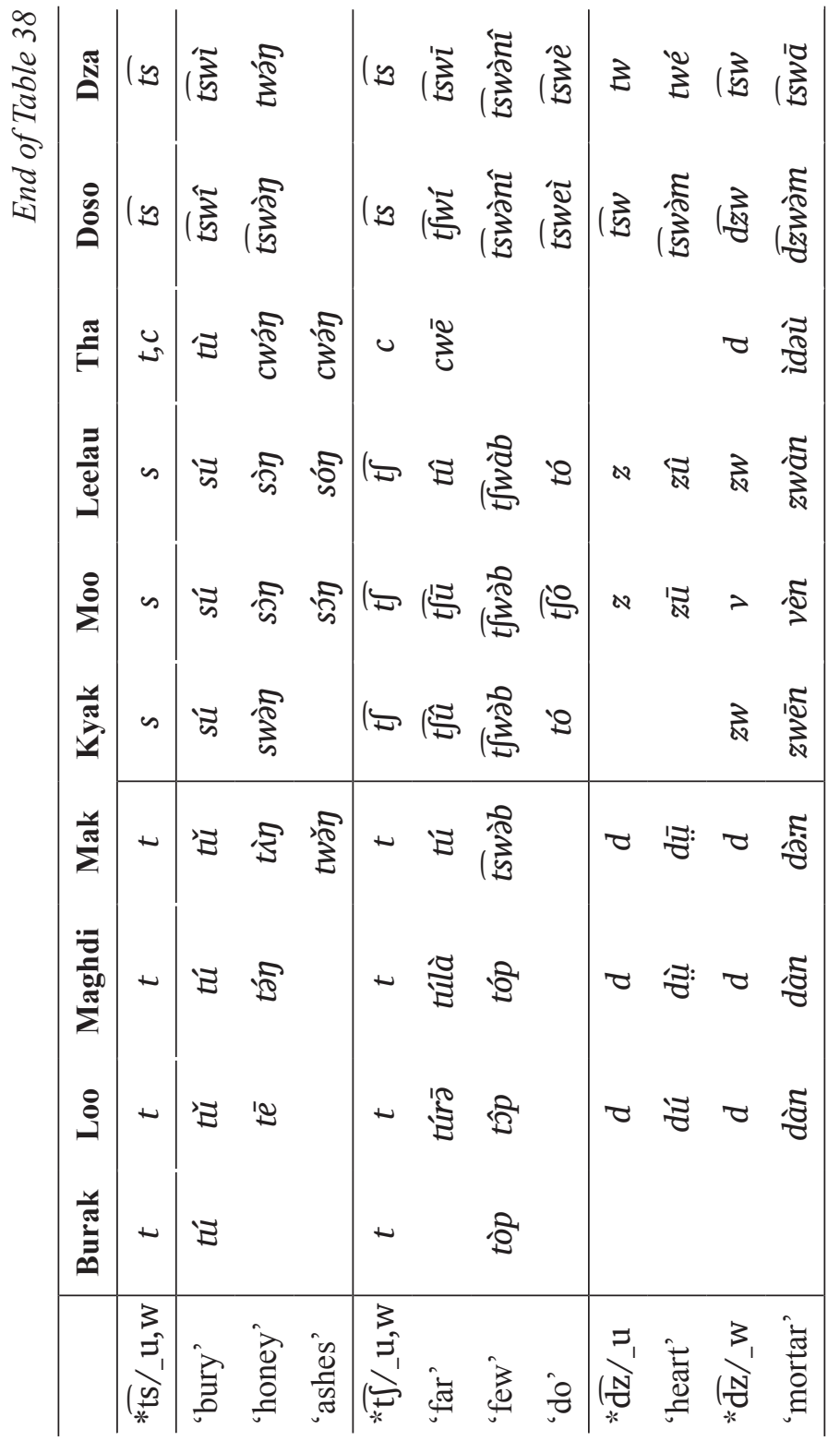


We have adopted sequential structures $C w$ and $C j$ as a working hypothesis, as opposed to secondary modifications within complex root-initial consonants $/ \mathrm{C}^{\mathrm{w}} /$ and $/ \mathrm{C}^{\mathrm{j}} /$, although the data offers possible arguments for either analysis. As for arguments for a sequential analysis, first, the economy principle disfavours secondary articulation because it would double the size of the phoneme inventory, and this is avoided by allowing $/ \mathrm{w} /$ or $/ \mathrm{j} /$ as the second of two onset consonants. Second, this onset structure automatically derives the fact that labial articulation does not appear with coda (syllable-final) consonants. Third, vowel/ diphthong alternations $[\mathrm{o}] \sim[\mathrm{w} \partial]$ and $[\mathrm{e}] \sim[\mathrm{j} \partial]$ in 3.2 associate the $[\mathrm{w}]$ or [j] with the following vowel, not with the preceding consonant. Fourth, certain sound changes to plosives and affricates take place before either $[\mathrm{u}]$ or $[\mathrm{w}]$, or before either [i] or [j], supporting an analysis in which $[\mathrm{w}]$ and $[\mathrm{j}]$ immediately follow the root-initial consonant like [u] and [i].

There are, however, counter-arguments favouring a secondary modification analysis. Many of the sound changes found in the data relate labialised or palatalised structures to unitary segments, so the simplest account of these changes would be from unit to unit, thus $b^{j}>f, n>j, p>k^{w}, k^{w}>\widehat{k p}, g^{w}>\widetilde{d z}, d^{w}>u, v^{w}>m, s^{w}>j^{w}$, etc. This argument is not quite watertight, for the important reason that structural re-interpretations by speakers of one sound as two, or two sounds as one, can themselves occur as historical change (Blevins 2004). Speaker re-interpretation is suggested in our data for 'brother, sister', which is heard as yə̀ in Tha but as jwā̄ in Kyak. Nevertheless, the sheer number of changes linking labialised or palatalised structures to unitary segments is striking, and appears to weigh in favour of the secondary modification analysis (countering the first argument against secondary modification). A second counter-argument is that affricates are also not admitted word-finally, so that a restriction disallowing all complex consonants word-finally would be a stronger explanation for the lack of word-final labialised or palatalised consonants (countering the second argument against secondary modification). Third, some sound changes restructure a sequence of two phonemes, such as $n a>j \tilde{a}$ and $j u>u i$, hence 
$\frac{a}{0}$

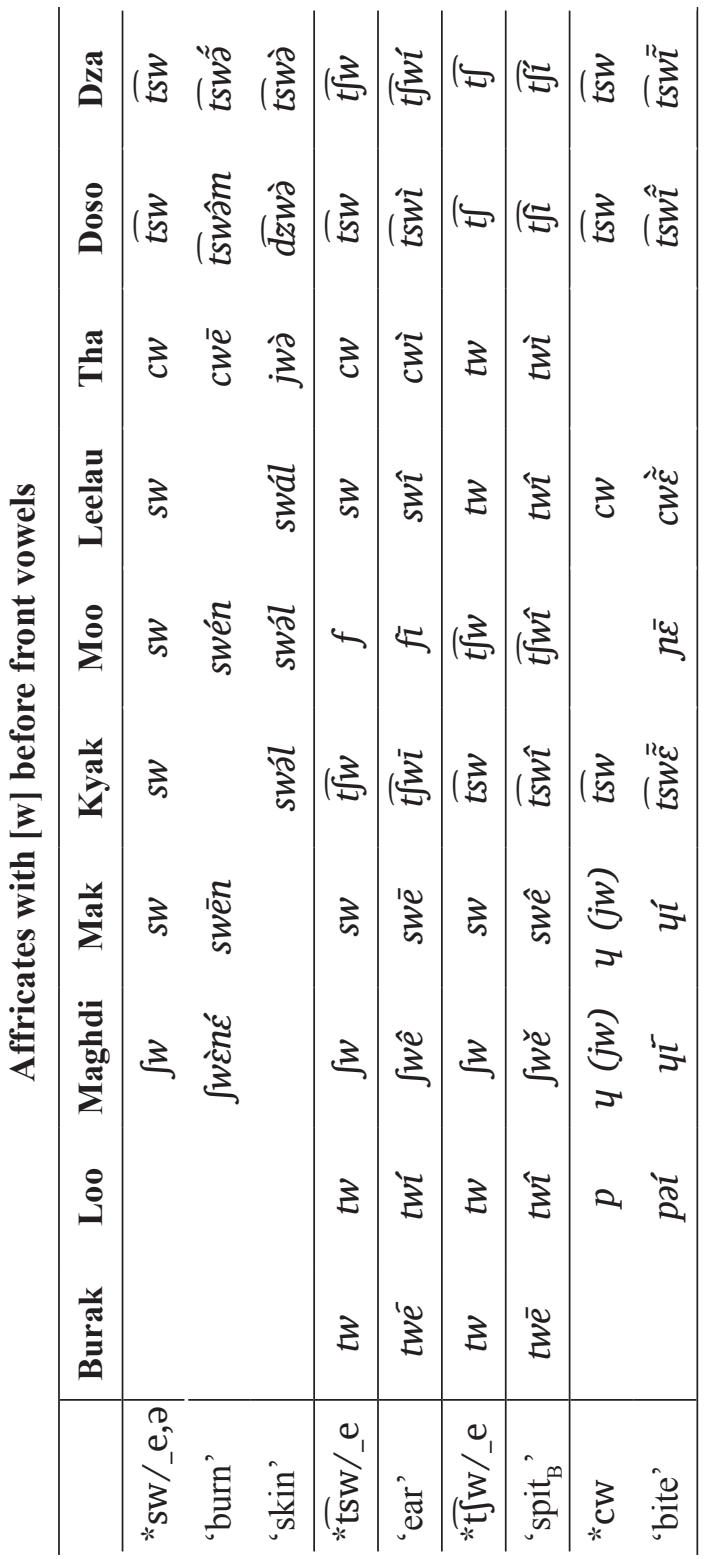


alternations involving on-gliding diphthongs can be interpreted the same way, thus $k^{w}>>k o, b^{j} a>b e$ etc. (countering the third argument against secondary modification). Fourth, there are sound changes conditioned by a following front vowel irrespective of whether labial articulation is present, thus $d\left({ }^{w}\right)>\sqrt[d z]{ }\left({ }^{w}\right) / i$. This appears to rule out [w] as the following segment, because the consonant is affricated before [i], which leaves labialisation as a feature of the consonant itself (countering the fourth argument against secondary modification).

The latter arguments suggest that our working analysis as onset $\mathrm{CC}$ sequences is unsatisfactory, but given the conflicting distributional and comparative evidence we suggest that phonetic evidence will be necessary to help resolve the matter in a given variety. Moreover, the variation already observed in $[\mathrm{Y}] \sim[\mathrm{jw}]$ implies that a variationist approach (allowing for variation between a segment with secondary modification and sequence of two segments), with or without a stratal approach (a sequence at one level and a secondary modification at another level), may provide a more satisfactory analysis.

\section{Conclusion}

Jen is a language cluster whose branches are united at 50\% lexical similarity. Autonyms distinguish ten communities within the cluster, but these form six language-like units at $90 \%$ lexical similarity, or more than six if for example Doso is considered distinct from Dza on phonological grounds, or if others are considered distinct on geographical grounds. A primary genetic branching between Burak-Loo-Maghdi-Mak and Kyak-Moo-Leelau-Tha-Doso-Dza is supported by lexicostatistics, lexical isoglosses, phonological isoglosses (nasalised vowels and $/ \mathrm{h} /$ ), morphological isoglosses (initial consonant alternations and rhyme alternations), and by numerous sound correspondences. Hence, the first seven Bikwin varieties are not a genetic group, although they are related culturally and geographically.

The complexity of sound change in the Jen language cluster is considerable. Some changes are conditioned by open vs. closed syllable 
structure, and others involve restructuring of two adjacent segments, both demonstrating that comparative analysis in this language cluster must continually consider structural context, instead of focusing only on individual segments. Some sounds are removed by one change and replenished by another, and there are several irregular changes. The complexity of sound change is most extensive in Tha and Doso-Dza, including roots in which every segment has undergone change, and including the development of voiceless approximant sounds not found in the more phonologically stable Bikwin varieties. A matter for future researchers is how the unusually extensive degree of sound change in the riverine Jen varieties might be explained.

The sheer complexity of sound change in the Jen language cluster also limits application to alphabet development. Some points are clear: implosives and the trill are lost in Dza and absent from its alphabet, but will need to be represented in other Jen languages, for which implosive symbols are readily available from Hausa orthography. The second branch is distinguished by nasalised vowels and $/ \mathrm{h} /$, therefore they only need to be represented in writing in that branch, as they are in Dza orthography. Because of the complexity of sound change, the more basic methodological step of comparing sound inventories (Dimmendaal 2011: 9) often seems more helpful for identifying alphabet needs in Jen languages (Othaniel 2017). This is partly because the Dza alphabet is based on a particularly large sound inventory in Dza from which other languages can select letters they need depending on which sounds are contrastive. This includes vowels, where sound correspondences are unstable and vowel systems may or may not retain the original contrasts, particularly the non-high front and back vowel contrasts $/ \mathrm{e} /-/ \varepsilon /$ and $/ \mathrm{o} /-/ \mathrm{\jmath} /$, and the central vowel contrasts $/ \mathrm{a} /-/ \partial /$ or $/ \partial /-/ \dot{i} /$.

Finally, irregular correspondences often suggest morphology in Jen languages that is not yet understood. Verbal stem alternations in the initial consonant are a feature of the earliest branching in the cluster, and also occur more recently in other verbs. Their functions are largely unclear here, except in two examples where consonant alternations distinguish direction ( * $g u ̣ b$ 'pull' vs. *lub 'pull up') and transitivity 
( ${ }^{\circ} \not{g b} \partial b$ 'hit' vs. "wəb/ ${ }^{*} z ə b$ 'kill'). Another initial consonant alternation $l / d$ occurs in nouns, also of unknown function, but it has been active recently in dialect clusters of the second branch, alternating between Leelau and Kyak-Moo in several roots ('fire', 'knee', 'locust-bean tree', 'tongue', 'yesterday'), and between Doso and Dza ('calabash', 'today'). Particularly in 'tongue', the $l / d$ alternation recalls evidence from other Niger-Congo languages that the lateral is an old affix (Norton 2018: 437). Other irregular patterns involve mid vowels and diphthongs, recalling similar relations in Chadic languages (Boyd 2002). These too are recently active, but whether they have a morphophonemic basis is unclear. Breathy voice appears irregularly, but is a historic feature of many root morphemes, distinct from modal voice and tone.

\section{Appendix. Reconstructions}

Reconstructions appear with the standard starred notation as in *kwin 'one'. IPA symbols used in the comparative wordlist that differ from widely used Africanist symbols have been replaced by the latter symbols in the reconstructions to facilitate their integration in further scholarship as in 'ya 'you (pl)' (Burak jà etc.). Where tone fits a series for H, M or $\mathrm{L}$ tone, it has been reconstructed. Absence of tone from the reconstruction indicates that we do not know what tone to reconstruct.

The following additional conventions have been used. Roots supported by only one of the two primary branches are presented in brackets as in ( $k a)$ 'grass', as the latter roots are ambiguous between retentions from proto-Jen or innovations of that primary branch. Roots with alternate forms in the two primary branches, that cannot be confidently resolved into one reconstructed form, are shown with the two forms separated by a slash as in *so/*swe 'snail'.

On each line, forms which are not considered cognate to the reconstructed form are given in brackets. There is an element of uncertainty in this, especially given the possibility of irregular initial consonant alternations in this language cluster. I have therefore sought to avoid use of brackets whenever I can see a possibility of cognacy between forms that partially resemble each other. 


\begin{tabular}{|c|c|c|c|c|c|c|}
\hline 今ั & 저요 & ह & . & ט & 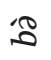 & 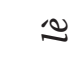 \\
\hline ஜ̊ & : 죠 & ' & 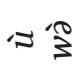 & 䒕 & ฮి & $\approx$ \\
\hline$\underline{\underline{E}}$ & 保孞 & $\stackrel{\mathfrak{Z}}{\mathrm{E}}$ & '? & $\tilde{\sigma}$ & i & $\therefore$ \\
\hline 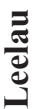 & : 尽 & ' & ও & $\approx$ & 6ீ & i \\
\hline$\frac{8}{\sum}$ & 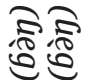 & '心 & : & 洋 & రి & $<\sim$ \\
\hline है & 路 & $\stackrel{\Re}{\xi}$ & $\sqrt{2}$ & '。 & 'ర & $\therefore \sim$ \\
\hline$\frac{\sqrt{3}}{\Sigma}$ & 决 & ఏ & 'ర్ల & 遅 & 通 & '̃ \\
\hline 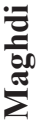 & 踣 & ’ & 'ర్ల & $\tilde{\sigma}$ & ס & $\mathbb{I}$ \\
\hline$\stackrel{8}{9}$ & ${ }^{1} \mathbb{E}^{\prime} \tilde{\Xi}$ & '얄 & ת & i。 & 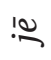 & $\stackrel{2}{2}$ \\
\hline 电 & $\tilde{\Xi} \approx$ & ’ & 'ర్ల & '0 & סָ: & '્ِટ \\
\hline : & 尽 $\underset{*}{ }$ & $\underbrace{\infty}_{*}$ & $\underbrace{\sqrt[*]{*}}_{*}$ & $\sigma_{*}$ & $\overbrace{*}^{\delta}$ & $\underset{*}{\frac{1}{*}}$ \\
\hline$\frac{\theta}{0}$ & $\tilde{G}$ & 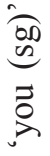 & 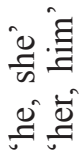 & 3 & $\begin{array}{l}\stackrel{\hat{\theta}}{\vec{b}} \\
\overrightarrow{0}\end{array}$ & ప্త \\
\hline
\end{tabular}

\begin{tabular}{|c|c|c|c|}
\hline$\stackrel{\mathfrak{N}}{\hat{0}}$ & 点 & 於 & 18 \\
\hline ஜ̊ & 隶 & 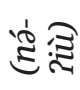 & '? \\
\hline$\stackrel{\text { E }}{E}$ & 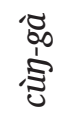 & 荵 & 疍 \\
\hline 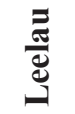 & 永 & 뮤 & $\tilde{\mathbb{B}}$ \\
\hline$\frac{8}{\sum}$ & $\underset{\Sigma}{\vdots}$ & :ి & $1 \omega$ \\
\hline$\underset{\vec{z}}{\frac{y}{\sigma}}$ & 雯 & : & I \\
\hline$\frac{y}{\Sigma}$ & : & రిత్రి & $\ddot{B}$ \\
\hline 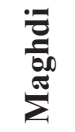 & 战 & 㤀 & 1త్ర \\
\hline$\stackrel{8}{8}$ & 占 & శ్రి & 冚 \\
\hline 를 & 这 & శ్రి & 疋 \\
\hline$\stackrel{\dot{0}}{\stackrel{0}{0}} \stackrel{0}{0}$ & $\frac{\sqrt[5]{\vdots}}{\grave{z}}$ & : & $\underset{*}{\mathbb{R}}$ \\
\hline$\frac{\tilde{\theta}}{0}$ & త్ర & $\sum_{0}^{0}$ & 导 \\
\hline
\end{tabular}




\begin{tabular}{|c|c|c|c|c|c|c|c|c|c|c|}
\hline ิึ & 决 & $\stackrel{尺}{\stackrel{尺}{\Sigma}}$ & 氶 & : & 罍 & $\sqrt{\frac{2}{\pi}}$ & న. & 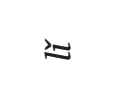 & $\sum_{i}^{\prime}$ & 㸃莣。 \\
\hline ஜ̊ & : & 胥。 & 结 & 离。 & 灾 & $\frac{\sqrt[5]{2}}{\frac{1}{2}}$ & ת. & $\approx$ & 点乐 & "స్తు \\
\hline$\stackrel{\Xi}{E}$ & 蛋 & 蛋 & '0 & 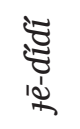 & 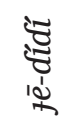 & 范 & 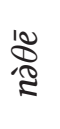 & 蛋 & '芯 & 胥 \\
\hline 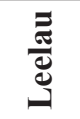 & 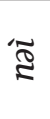 & $\mathfrak{Z}$ & 苾 & 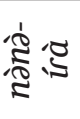 & 荵 & 周 & त्रे & $\approx$ & 苫嗾 & 苫忐 \\
\hline$\stackrel{8}{\Sigma}$ & 幽 & 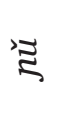 & 离 & & 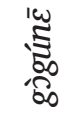 & $\begin{array}{l}\frac{0}{\sqrt[3]{3}} \\
\frac{5}{4}\end{array}$ & $\frac{i}{3}$ & 疍 & 岕志 & 卖 \\
\hline 类 & IE్ల & 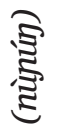 & 悤 & 吝 & 岕 & $\begin{array}{l}\text { के के } \\
\text { के }\end{array}$ & के & 察这染 & 定点 & $\begin{array}{l}\text { శ్రి } \\
\text { 'ర్ర }\end{array}$ \\
\hline$\frac{y}{\Sigma}$ & Iָ & $\frac{\sqrt{3}}{3}$ & 点 & ס்ֶ & $\frac{D_{0}^{\infty}}{\sum^{\infty}}$ & 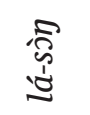 & $\frac{2}{5}$ & $\frac{\pi}{\frac{\pi}{2}} i \frac{\sqrt{2}}{\frac{1}{2}}$ & 演志 & 芯芯 \\
\hline $\begin{array}{l}\frac{5}{0} \\
\frac{1}{60} \\
\sum \\
\sum\end{array}$ & 高 & 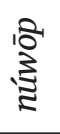 & 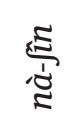 & $\frac{\omega}{d}$ & סֶ. & $\frac{5}{\frac{1}{0}}$ & 这 & 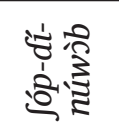 & $\underbrace{\frac{5}{3}}_{\substack{5 \\
\vdots}}$ & 总总 \\
\hline తి & 壳 & :0 & 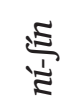 & 'ְ & 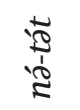 & 恚 & 응 & के & 宓 & 莡 \\
\hline صี & 岕: & ฉิ & 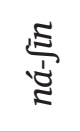 & 'ְ'ٍ & 总 & 荵 & त̂ & 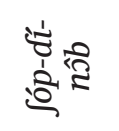 & $\frac{\sqrt[5]{5}}{\frac{1}{2}}$ & 莡 \\
\hline 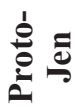 & $\underset{*}{\mathbb{E}}$ & $\underset{*}{\mathbb{Z}}$ & & & & & $\sum_{x}^{\infty}$ & & & \\
\hline$\frac{\tilde{\sigma}}{0}$ & 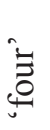 & $\underbrace{0}_{0}$ & . & $\sum_{0}^{0}$ & $\frac{2}{000}$ & . & Ðే) & 异 & 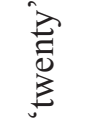 & 坣总 \\
\hline
\end{tabular}




\begin{tabular}{|c|c|c|c|c|c|c|c|c|c|c|c|}
\hline$\stackrel{\text { న }}{\varrho}$ & 实: & 芑 & 竞 & 官: & $\approx$ & 疍 & '̊̃ & है & $\therefore$ & 'ミ゙ & $\frac{2}{2}$ \\
\hline ஜ & ईొ & 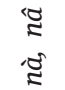 & 绍 & శ్ర & ĩ & (3) & ) & $\overbrace{}^{10}$ & $\frac{10}{3}$ & 孞 & ') \\
\hline$\underset{乛}{\tilde{E}}$ & है & 菖 & 墕 & 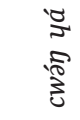 & క్ & $\frac{\sqrt[3]{0}}{\sqrt[3]{0}}$ & : & $\begin{array}{l}\frac{1}{2} \\
\frac{1}{2} \\
\frac{1}{3}\end{array}$ & $\frac{\sqrt[1]{\pi}}{\sqrt[3]{\pi}}$ & $\stackrel{\text { : }}{\text { I }}$ & $\frac{\pi}{2}$ \\
\hline 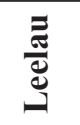 & है & '品 & 济 & : & $\begin{array}{l}\square \\
0 \\
8\end{array}$ & స్ & 'ڤ & $\frac{\sqrt{2}}{\frac{3}{3}}$ & ؛ั & ミ & 'ర \\
\hline$\sum^{8}$ & है & '足 & 涪 & న్ & : & है & §ీ & $\stackrel{\curvearrowright}{\curvearrowright}$ & 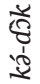 & 战 & 'ర్ \\
\hline 䒕 & స్ & '્ֶさ & 侪 & 'క్ & $i \tilde{\sigma}$ & है & '̊ి & 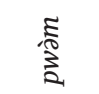 & $\frac{\pi}{3}$ & ఏే & 'ర్ \\
\hline$\sum^{\frac{y}{z}}$ & : & 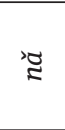 & 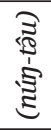 & $\underbrace{\sqrt[5]{D}}$ & 苟 & 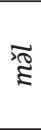 & $\begin{array}{l}\text { ¿̊ి } \\
\text { ¿̊ }\end{array}$ & $\begin{array}{l}\frac{\sqrt{2}}{\sqrt[3]{2}} \\
\frac{\sqrt[3]{2}}{2}\end{array}$ & ஜัँ & 於 & $\mathbb{R}$ \\
\hline 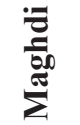 & 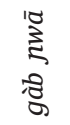 & 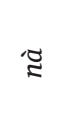 & 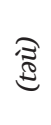 & 空 & : *్రి & 逽 & 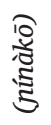 & $\frac{\sqrt[3]{3}}{\sqrt[3]{3}}$ & :ั & 淰 & 证 \\
\hline$\stackrel{8}{9}$ & $\begin{array}{l}\frac{1 \omega}{8} \\
\frac{1}{8}\end{array}$ & '足: & 点 & క్ & ఫ్రి & $\widetilde{\Re}$ & iీ & $\frac{10}{3}$ & $\frac{\pi}{\delta}$ & 㓍 & : \\
\hline 光 & శ్ & ‘足: & $\frac{\sqrt[2]{2}}{\sqrt[i]{5}}$ & 'స్ & 貉 & 疋 & $\frac{\frac{\omega}{1}}{\frac{1}{00}}$ & $\frac{\omega}{\frac{1}{3}}$ & :ั & 於 & $\mathbb{2}$ \\
\hline 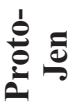 & స్?: & $\underset{*}{\mathbb{V}}$ & $\underset{*}{\nabla}$ & ڤై & : & $\underset{*}{ే}$ & $\underset{*}{\grave{\Xi}}$ & $\frac{\sqrt[3]{*}}{\frac{\pi}{*}}$ & $\frac{\pi}{8}$ & 㓍 & 承疋 \\
\hline$\frac{\tilde{c}}{0}$ & 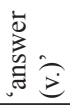 & हే छ & है & 䜦 & $\frac{y}{0}$ & $\begin{array}{l}\frac{y}{0} \\
0 \\
0\end{array}$ & تే & 蒫 & $\begin{array}{l}\bar{y} \\
\frac{\tilde{y}}{\tilde{z}} \\
0 \\
0\end{array}$ & $\begin{array}{l}\ddot{\bar{\Xi}} \\
0\end{array}$ & 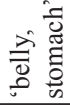 \\
\hline
\end{tabular}




\begin{tabular}{|c|c|c|c|c|c|c|c|c|c|c|c|}
\hline ڤึ & : & "ర్ & $\int_{12}^{12}$ & 'ह & مَ & 'సి. & 录 & 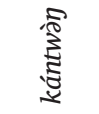 & 3 & '̊ & "ミב \\
\hline ஜ̊ & $\approx$ & ": & $\left(\frac{2}{3}\right.$ & 凉 & ๘ర & : & 录 & 胥 & 'ర) & $\hat{\Xi}$ & 'ב \\
\hline$\stackrel{\mathbb{E}}{E}$ & 1 & ' & ":శ్ర & '气 & 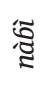 & $\overline{2}$ & 趦 & : & సे & ' & "I \\
\hline 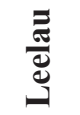 & 㝕 & "ర) & נె & : & $\begin{array}{l}\frac{\tilde{S}}{0} \\
0 \\
0\end{array}$ & "ה & $\frac{\text { s: }}{3}$ & 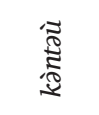 & : & 'ミ゙ & 苣 \\
\hline$\sum^{8}$ & ' $\tilde{\Omega}$ & ": & $\stackrel{\mid \omega}{ٍ}$ & $\stackrel{\Omega}{\text { I }}$ & $\widetilde{\sigma}$ & $\sqrt[3]{\mathrm{N}}$ & 疋 & $\frac{\sqrt[3]{3}}{\sqrt[3]{3}}$ & : & ' $\vec{\Xi}$ & ' \\
\hline$\frac{y}{\pi}$ & $\check{\Omega}$ & 芯 & (ne & ¿ & 胥 & 'స్ & 迅 & 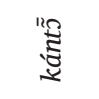 & ஜి & ‘ & $\cong$ \\
\hline$\sum^{\frac{v}{\sigma}}$ & $\approx$ & స్థ & 'న & స్తి & 点 & $\frac{10}{2}$ & $\frac{\sqrt[T]{2}}{3}$ & 荵 & กิ & 'ڤ̃ & ? \\
\hline 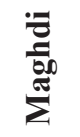 & $\approx$ & $\widehat{\delta}_{0}$ & $\sqrt[2]{2}$ & $\frac{2}{2}$ & $\frac{\tilde{5}}{\tilde{\sigma}}$ & 'P: & 요 & $\frac{\sqrt[3]{3}}{\sqrt[3]{0}}$ & శి & ' & 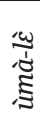 \\
\hline$\stackrel{8}{\varrho}$ & '0 & 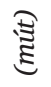 & $\check{\check{\Omega}}$ & $\stackrel{\text { డ్ల }}{\sim}$ & $\tilde{\sigma}$ & 孞 & : క్రి & శ్రి & ళृ & ‘ $\tilde{\xi}$ & : \\
\hline 气ี & $\approx$ & 忥 & క్ & ? & : & $\stackrel{20}{3}$ & : క్రి & $\frac{\sqrt[2]{2}}{i \frac{1}{2}}$ & $\stackrel{\vartheta}{\mathscr{Z}}$ & 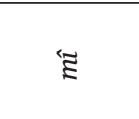 & : है \\
\hline 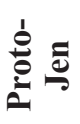 & $\approx \frac{\infty}{*} \underset{*}{*}$ & s) & 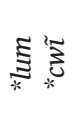 & $\underbrace{\omega}_{*}$ & $\tilde{\nabla}$ & $\frac{x^{n}}{\sum^{n}}$ & $\frac{\mathfrak{\pi}}{*}$ & 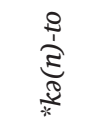 & \begin{tabular}{l}
$\frac{8}{8}$ \\
\multirow{2}{*}{} \\
$*$
\end{tabular} & $\vec{\xi}$ & $\underset{*}{\mathbb{Z}}$ \\
\hline$\frac{\hat{0}}{0}$ & 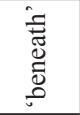 & $\frac{600}{3}$ & 苋 & : & $\frac{\frac{y}{0}}{\frac{\pi}{0}}$ & $\frac{7}{0}$ & : & हैं & 弟 & 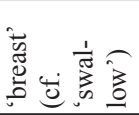 & 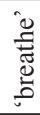 \\
\hline
\end{tabular}




\begin{tabular}{|c|c|c|c|c|c|c|c|c|c|c|c|}
\hline$\stackrel{\text { N }}{0}$ & "న. & $i_{103}^{5}$ & $\widehat{3}$ & $\frac{\mathfrak{Z}}{\frac{1}{1}}$ & ( & 领 & 'ర్ల & §ั & है & ’ & "ᄑू \\
\hline ஜ & $" \mathbb{2}_{0}$ & 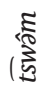 & $\overbrace{\substack{3 \\
3}}^{5}$ & 矛 & $\approx$ & 芯 & 'ర্s & $\tilde{\widetilde{s}}$ & 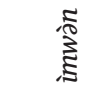 & '. & $\sim$ \\
\hline 를 & '? & ड़้ & 胥 & 焉 & $\tilde{\Xi}$ & 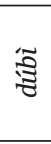 & 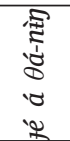 & $\frac{\sqrt[0]{3}}{\sqrt[3]{3}}$ & స્心 & 旁 & "gु \\
\hline 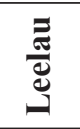 & 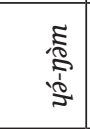 & $\mathbb{E}$ & "ָָ & 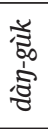 & $\tilde{\mathbb{\delta}}$ & 范 & 10 & 荵 & 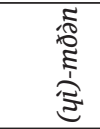 & స్ & 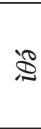 \\
\hline$\frac{8}{2}$ & 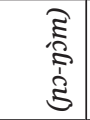 & 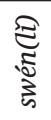 & "ָָ & 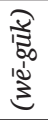 & \& & II & 'ర్ల & 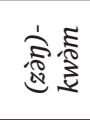 & $\stackrel{3}{3}$ & స్ & in \\
\hline$\frac{y}{\pi}$ & . & $\mathbb{E}$ & "ָָ & 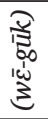 & $\stackrel{\omega}{\sigma}$ & I & "D & : & 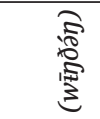 & క్రి & $\mathbb{S}$ \\
\hline$\stackrel{\text { है }}{\sum}$ & 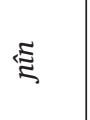 & के & '2゙ & $\frac{\pi}{\frac{\pi}{d}}$ & : & 莣 & 'ర్ల & $\frac{\frac{\sqrt{2}}{3}}{\frac{1}{3}}$ & 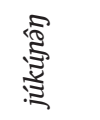 & 站 & $\$$ \\
\hline 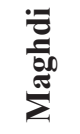 & 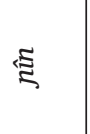 & 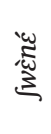 & $': Z$ & $\frac{\sqrt{3}}{i \frac{1}{\pi}}$ & 实 & $\tilde{\mathfrak{T}}$ & $\stackrel{0}{0}$ & 行 & $::$ & $\underbrace{8}$ & $\begin{array}{l}\text { iz } \\
\text { is }\end{array}$ \\
\hline ஜ̊ & 占 & 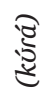 & '2' & $\frac{\sqrt[3]{1}}{\frac{1}{8}}$ & $\ddot{d}$ & $: \Xi$ & "రు & $\frac{\sqrt[3]{\frac{1}{2}}}{\frac{1}{2}}$ & $: \mathbb{Z}$ & $\frac{7}{8}$ & iร \\
\hline ตै & $\begin{array}{l}\mathfrak{\Xi} \\
\vdots \\
\mathfrak{\Xi}\end{array}$ & ?్ָరి & $': Z$ & $\frac{\sqrt[3]{d}}{\frac{d}{\delta}}$ & $\ddot{\sigma}$ & $\Xi$ & 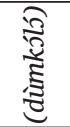 & 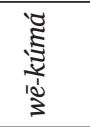 & 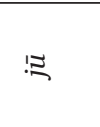 & $\frac{8}{8}$ & i \\
\hline 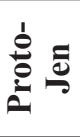 & $\underset{*}{\stackrel{2}{\overparen{2}}}$ & $\overbrace{*}^{5}$ & $(\overrightarrow{\widetilde{Z}}$ & 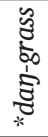 & $\psi_{*}^{\omega}$ & $\frac{\tilde{D}}{\frac{1}{*}}$ & $\underset{*}{\not}$ & $\aleph_{*} \frac{\tilde{z}}{*}$ & 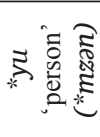 & 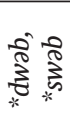 & $\tilde{*}$ \\
\hline$\frac{\hat{o}}{0}$ & 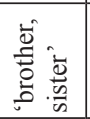 & हే & పై & กี & 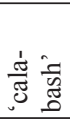 & 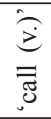 & . & 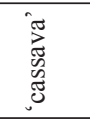 & :0 & 齐 & 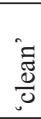 \\
\hline
\end{tabular}




\begin{tabular}{|c|c|c|c|c|c|c|c|c|c|c|c|}
\hline กี & 倞 & ’े & צֶּ" & $\stackrel{3}{3}$ & '心 & ర్ల: & $\stackrel{\sqrt{9}}{\widetilde{N}}$ & 进 & $\stackrel{3}{2}$ & $\frac{乛}{8}$ & $\frac{1}{8}$ \\
\hline ஜ & 经 & $\begin{array}{l}\text { కే } \\
\text { ఏે }\end{array}$ & " & $\stackrel{1}{3}$ & '心 & క్ & 绣 & 芯 & 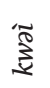 & : & 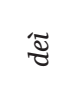 \\
\hline$\underset{\Xi}{E}$ & 孞 & 定 & تt" & 3 & 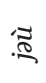 & ఏ & $\frac{8}{80}$ & 芯 & 8 & 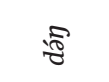 & కัँ \\
\hline 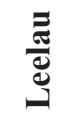 & $\tilde{\Phi}$ & 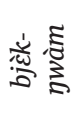 & $\stackrel{?}{\stackrel{2}{*}}$ & 3 & :으 & \begin{tabular}{l}
$\sqrt[5]{0}$ \\
\multirow{2}{0}{} \\
$\infty$
\end{tabular} & 蛋 & 今్ & త్రి & : & 㐾 \\
\hline$\frac{8}{2}$ & ¿ & 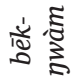 & ह్ & 'ొ & ?: & న్త్ర & $\Xi$ & 雾 & 胥 & $\frac{\mathbb{1}}{8}$ & $\leqslant$ \\
\hline 音 & 幽 & 空㤀 & : & $\stackrel{\omega}{3}$ & !으 & 忍 & $\Xi$ & 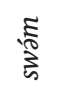 & 'క & $\frac{\sqrt{\mathbb{D}}}{8}$ & 垈 \\
\hline$\frac{v}{\Sigma}$ & $\tilde{\mathbb{Z}}$ & 录 & ? & $: \stackrel{0}{\circ}$ & : & $\begin{array}{l}8 \\
\frac{1}{8} \\
\text { i }\end{array}$ & 里 & क्रुऽ & 乎 & : & 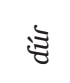 \\
\hline $\begin{array}{l}\frac{5}{0} \\
\frac{1}{60} \\
\sum \\
\sum\end{array}$ & $\sqrt[5]{5}$ & 范 & ह : & $: \approx$ & 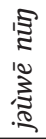 & $\begin{array}{l}\text { 'ర } \\
\text { : } \\
\text { : }\end{array}$ & : & 诤 & है & $\frac{\sqrt{0}}{8}$ & $\begin{array}{l}\frac{10}{\mathfrak{z}} \\
\text { :ี }\end{array}$ \\
\hline$\stackrel{8}{\varrho}$ & $\underset{\mathfrak{s}}{5}$ & $\begin{array}{l}\text { :ै } \\
\text { है } \\
\text { है }\end{array}$ & : & 汹 & !음 & 总 & 里 & 逜 & ग्ञ్ & 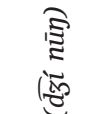 & ঐू \\
\hline ตี & $\underset{\mathfrak{s}}{\mathfrak{5}}$ & 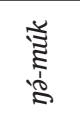 & : & $: \approx$ & ?: & : & 岕 & 通 & : & 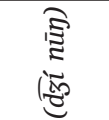 & 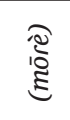 \\
\hline 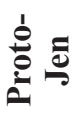 & 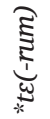 & 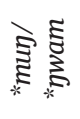 & $\underset{*}{\mathbb{E}}$ & 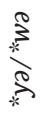 & $\overbrace{\pi}^{2}$ & 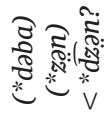 & : & 霍 & हి & 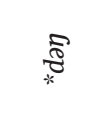 & $\sum_{*}^{0}$ \\
\hline$\frac{\tilde{c}}{0}$ & $\frac{\overline{0}}{\overline{0}}$ & مَّ & $\overline{0}$ & हే & 긍 & 莽 & हैं & $\begin{array}{l}1 \\
\dot{0} \\
0 \\
0 \\
0 \\
0\end{array}$ & $\bar{\Xi}$ & 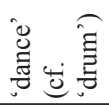 & 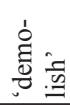 \\
\hline
\end{tabular}




\begin{tabular}{|c|c|c|c|c|c|c|c|c|c|c|c|c|}
\hline ̊ี & క్ & '̊̊ & $\approx$ & 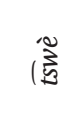 & 竎 & 站 & 芯 & : & 结 & 官: & 諒 & 'ָ \\
\hline $\begin{array}{l}\text { ஜ } \\
\text { ஜ̂ } \\
\text { ஜ }\end{array}$ & కి & 'ֵ̊ & : & $\widehat{(\widetilde{\Xi}}$ & $\sum_{:=0}^{0}$ & 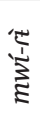 & 宫 & $\frac{\sqrt[\pi]{8}}{\delta}$ & 结 & శ్ర & $\underbrace{\frac{5}{3}}_{\substack{\frac{1}{3} \\
\frac{3}{3}}}$ & 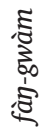 \\
\hline$\underset{E}{\tilde{E}}$ & క్ & s' & $\tilde{\sigma}$ & $\stackrel{2}{2}$ & 胥 & 茎 & ミ & 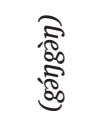 & 伃。 & 凉 & $\begin{array}{l}\widetilde{3} \\
0 \\
0 \\
0 \\
0\end{array}$ & 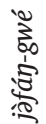 \\
\hline 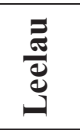 & చิ & ' & 怘 & '? & $\overbrace{}^{0}$ & 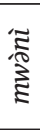 & 总 & : & క్ & 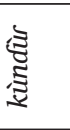 & $\frac{\sqrt[5]{3}}{\frac{3}{8}}$ & 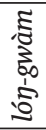 \\
\hline$\frac{8}{2}$ & క్ & 心 & 要 & 谂 & '્ટ & $\begin{array}{l}\text { ఏ్ } \\
\text { ఏે }\end{array}$ & 帘 & $\frac{\pi}{8}$ & 芆 & 迅 & $\frac{5}{8}$ & 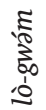 \\
\hline$\stackrel{y}{\frac{1}{\sigma}}$ & కి & 怘 & $\tilde{E}$ & '용 & 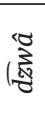 & $\begin{array}{l}\text { ఏई } \\
\text { ఏे }\end{array}$ & 古 & శ্ & 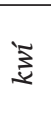 & 芳 & (蛋 & 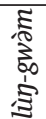 \\
\hline$\frac{\mathscr{J}}{\Sigma}$ & 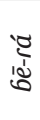 & : & 通 & 苂 & $\overbrace{}^{0}$ & $\begin{array}{l}\text { ' } \\
\text { ఏે }\end{array}$ & : స્ּ & $\frac{\mathbb{1}}{8}$ & $\begin{array}{l}\tilde{z} \\
\text { క్ }\end{array}$ & 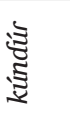 & $\frac{10}{\grave{1}}$ & $\begin{array}{l}\tilde{\delta} \\
\text { పे } \\
\vdots \\
0\end{array}$ \\
\hline 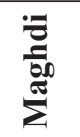 & $\frac{0}{i \frac{1}{6}}$ & : & $\tilde{\Xi}$ & 'జֶ & '0 & 总 & ' & $\frac{15}{8}$ & $\begin{array}{l}\tilde{z} \\
\text { క్ }\end{array}$ & $\frac{2}{8}$ & $\underbrace{10}$ & $\begin{array}{l}\text { हీ } \\
\text { : } \\
0\end{array}$ \\
\hline ஜ̊ & : & ! & $\tilde{\Xi}$ & $\stackrel{|\omega|}{\Sigma}$ & క్రి & 胥 & ’̊ & : & 艿 & 䒿 & 空 & $\stackrel{\tilde{\Xi}}{\tilde{0}}$ \\
\hline 气ี & 岕 & ?: & 㝒 & 岂 & לे & 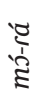 & $\stackrel{2}{2}$ & : & $\begin{array}{l}\frac{10}{10} \\
\frac{1}{2} \\
\frac{1}{2}\end{array}$ & 恣 & ’气 & 谞 \\
\hline 율 & $\sum_{*}^{5}$ & $\overbrace{*}^{\substack{k \\
*}}$ & $\tilde{\nabla}$ & 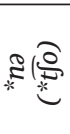 & $\sum_{*}^{\sigma}$ & 齐 & 趈 & $\underset{\mathbb{3}}{\mathbb{3}}$ & $\frac{\sum_{*}^{\Perp}}{*}$ & 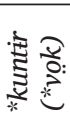 & 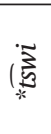 & స్ \\
\hline$\frac{0}{0}$ & :0 & 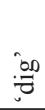 & $\stackrel{\vec{y}}{3}$ & "용 & of & 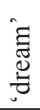 & 首 & 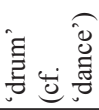 & $\vec{E}$ & $\begin{array}{l}\bar{t} \\
\bar{z}\end{array}$ & $\hat{\tilde{J}}$ & 胥 \\
\hline
\end{tabular}




\begin{tabular}{|c|c|c|c|c|c|c|c|c|c|c|c|c|c|}
\hline$\stackrel{\text { N }}{\mathrm{\rho}}$ & $\stackrel{D}{D}$ & 宽 & "ח & 'O: & 宝 & 10 & 1 芯 & ' & 'ס्] & 滪 & (ర્心: & 串 & |న్వ: \\
\hline 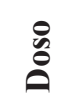 & $\sqrt{8}$ & 串 & 偦 & '心 & 尺 & 0 & 这 & 起 & ' & )ิ & $\begin{array}{l}\tilde{క} \\
\text { (్రి }\end{array}$ & 需 & '5 \\
\hline$\underset{乛}{\tilde{E}}$ & $\sqrt{8}$ & 官 & 点 & శ్రి & 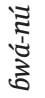 & $\therefore$ & ड़ & 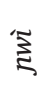 & : & : & " & $\underline{3}$ & '. \\
\hline 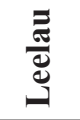 & 放 & 5 & 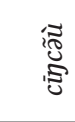 & $\frac{U}{\widehat{N}}$ & $\mathfrak{\Xi}$ & 0 & $\tilde{Z}$ & ఏે & $\frac{8}{8}$ & 结 & : & 疍 & $\tilde{\mathrm{E}}$ \\
\hline$\frac{8}{2}$ & $\widetilde{D}$ & $\$$ & $\begin{array}{l}\frac{\pi}{0} \\
\text { శ్రీ }\end{array}$ & $\frac{\pi}{\alpha}$ & 导 & 10 & 渂 & '્ડ & $\mathbb{Z}$ & 空 & $\stackrel{\circ}{\Omega}$ & క్ర & $\begin{array}{l}10 \\
10 \\
\frac{10}{10} \\
3 \\
3 \\
\end{array}$ \\
\hline$\frac{v}{\pi}$ & $\sqrt{2}$ & 胥 & 黛 & రั & $\mathfrak{\Xi}$ & 10 & 涼 & '气 & 10 & $\dddot{Z}$ & 贫 & 5 & ס \\
\hline$\sum^{\frac{y}{z}}$ & $\widetilde{\Phi}$ & $\sqrt{8}$ & 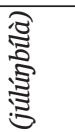 & : స్ర & $\Xi$ & : & 'ZZ & $\sum^{5}$ & 18 & 莡 & 8 & $\tilde{8}$ & 苋 \\
\hline $\begin{array}{l}\text { 可 } \\
\frac{\pi}{00} \\
\sum\end{array}$ & $\widetilde{D}$ & $\stackrel{5}{8}$ & 尝 & $\frac{\pi}{\overparen{B}}$ & $\mathfrak{\Xi}$ & : & : & 岂 & 'ָ & 莕 & 8 & 'రి & 胥 \\
\hline ְ̊ & $\sqrt{D}$ & $\sqrt{5}$ & 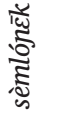 & 究 & $\mathfrak{\Xi}$ & ':: & 点 & '气 & 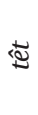 & 芌 & 5 & $\begin{array}{l}\text { ' } \\
\text { కి }\end{array}$ & 岂 \\
\hline 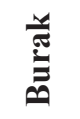 & $\sqrt{D}$ & 10 & 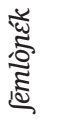 & 帘 & $\geqq$ & '̊ & 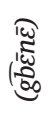 & ’्ે & ' & 莒 & 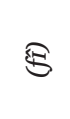 & ! : & 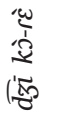 \\
\hline 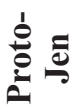 & 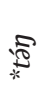 & $\stackrel{\overparen{D}}{\stackrel{2}{*}}$ & 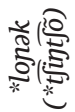 & శ్: & $\underset{*}{\mathbb{Z}}$ & $*$ & 柆 & 趈 & $\underset{*}{*}$ & 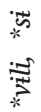 & 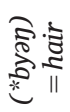 & ऐે & \% \\
\hline$\frac{n}{0}$ & $\overline{\tilde{J}}$ & $\begin{array}{l}60 \\
600 \\
0 \\
0\end{array}$ & 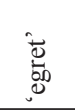 & d & 㐫 & 产 & 离 & 氜 & 离 & 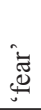 & 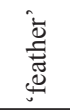 & 离 & 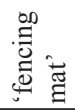 \\
\hline
\end{tabular}




\begin{tabular}{|c|c|c|c|c|c|c|c|c|c|c|c|c|c|}
\hline อั & $\mathbb{B}$ & 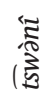 & '尔 & $\frac{\sqrt{2}}{\text { 空 }}$ & 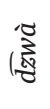 & 䜀。 & 'ֶ, & 'es & 䆓 & î & 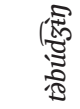 & 蛋 & 泣 \\
\hline ஜ & $B$ & 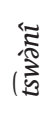 & $\begin{array}{l}\text { हొ } \\
\stackrel{5}{5}\end{array}$ & $\mathcal{E}$ & '્ટે & 尽。 & $\begin{array}{l}\text { हే } \\
\text { : }\end{array}$ & ' & 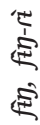 & $\stackrel{8}{8}$ & 结 & 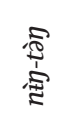 & $\mathfrak{\Phi}$ \\
\hline$\stackrel{\Xi}{E}$ & $\stackrel{2}{2}$ & 谞 & $\begin{array}{l}\text { बि } \\
\text { 尽 }\end{array}$ & iw & 'ָ & : & 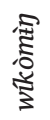 & ๘ & 4 & $\frac{0}{\frac{1}{5}}$ & $\frac{\sqrt[2]{\mathbb{2}}}{\sqrt[0]{0}}$ & $\begin{array}{l}\text { 蛋 } \\
\text { 突 }\end{array}$ & $\widetilde{U}$ \\
\hline$\frac{\Xi}{\overparen{\Xi}}$ & हृ & : & 䠉: & 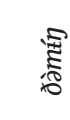 & కి & 果 & : & $\widetilde{0}$ & 点 & 需 & $\begin{array}{l}\text { కే } \\
\text { హ్ }\end{array}$ & 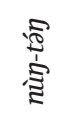 & i⿱宀'心 \\
\hline$\frac{8}{2}$ & हृ & 整 & 昰 & 㣽 & : & $\stackrel{P}{\mathrm{H}^{\circ}}$ & $\begin{array}{l}\frac{0}{12} \\
\text { בิ }\end{array}$ & 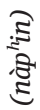 & 忐 & 尔 & 孞 & 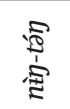 & $\ddot{\omega}$ \\
\hline 章 & हृ & $\stackrel{\frac{10}{3}}{\stackrel{5}{5}}$ & 焉 & 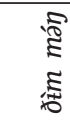 & 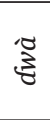 & 果 & : & $\underset{N}{\widetilde{w}}$ & 变 & 离 & 空 & 蛋 & $\underset{\tilde{\omega}}{\mid \omega}$ \\
\hline$\sum_{z}^{\frac{V}{J}}$ & $\sqrt{8}$ & 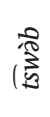 & 尔 & 栉 & 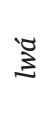 & $\widetilde{\varpi}$ & 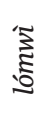 & $\widetilde{乛}$ & $\frac{\frac{\sqrt{3}}{2}}{\frac{2}{2}}$ & 胥 & 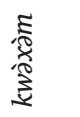 & $\begin{array}{l}\sqrt[5]{9} \\
\frac{1}{3} \\
:\end{array}$ & $\ddot{\omega}$ \\
\hline 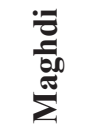 & 'త్వ: & ': & 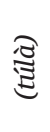 & 岕 & ఏే & '。 & $\frac{20}{2}$ & 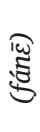 & 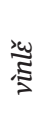 & 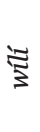 & $\frac{\tilde{n}}{\frac{5}{3}}$ & 怘惫 & $: \square$ \\
\hline ஜ & $\stackrel{\mid \omega}{\Xi}$ & శ્వి & 偲 & $\underbrace{1}$ & ఏే & 结 & కొ & 妾 & $\frac{\text { i⿱艹 }}{\text { iี }}$ & 莺 & 鸹 & 茎通 & ' \\
\hline คै & 莡 & క్రి & $\underbrace{\stackrel{2}{\sigma}}$ & 谞 & 'ర్ & 脑 & 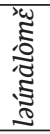 & $\underset{i \sim}{i \sim}$ & $\frac{10}{\approx}$ & 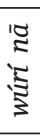 & 结 & 宗密 & 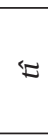 \\
\hline 递 & $\underset{*}{2}$ & $\overbrace{*}^{\stackrel{5}{5}}$ & 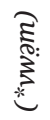 & 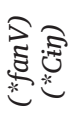 & $\sum_{*}^{\sigma}$ & 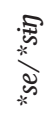 & $\underset{\substack{* \\
*}}{\mathbb{B}}$ & $\underset{\pi}{\mathbb{J}}$ & $\underset{\substack{\perp \\
*}}{\gtrless}$ & $\frac{7}{3}$ & 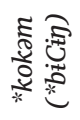 & 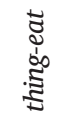 & 倞 \\
\hline$\frac{\mathscr{\theta}}{0}$ & 冚 & 常 & 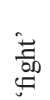 & $\stackrel{\vec{n}}{\stackrel{\vec{f}}{\vec{B}}}$ & $\stackrel{0}{0}$ & $\overline{\tilde{n}}$ & $\stackrel{\vec{\pi}}{\overline{0}}$ & 30 & 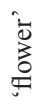 & 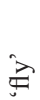 & రి & ت & 苛 \\
\hline
\end{tabular}




\begin{tabular}{|c|c|c|c|c|c|c|c|c|c|c|c|c|}
\hline$\stackrel{\text { พ̃ }}{\hat{2}}$ & 济 & $\stackrel{\mathbb{2}}{: 0}$ & 2 & is & $\stackrel{2}{2}$ & $: 0$ & ': & "స్ & 怘 & $\stackrel{2}{2}$ & 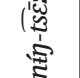 & $\stackrel{2}{\varrho}$ \\
\hline $\begin{array}{l}\text { ஜ } \\
\text { ह̊ } \\
0\end{array}$ & $\frac{3}{3}$ & 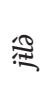 & : & is & 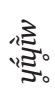 & $\mathfrak{3}$ & 竞 & 必 & 恚: & $\stackrel{1}{2}$ & 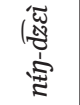 & 客 \\
\hline$\stackrel{\Xi}{E}$ & 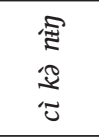 & $\therefore \approx$ & 8 & $\mathbb{E}$ & $\frac{\mathbb{Z}}{\mathbb{Z}}$ & 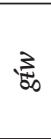 & పే & 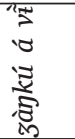 & d & ’̊ & - & 尽 \\
\hline 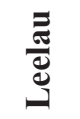 & $\frac{\sqrt[3]{2}}{\sqrt[5]{5}}$ & 象 & 8 & $B$ & 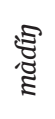 & 奈 & 芯 & 恚 & క్ & 㓠 & 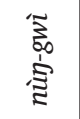 & 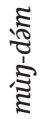 \\
\hline$\stackrel{8}{\varepsilon}$ & $\frac{\sqrt[3]{2}}{\sqrt[n]{n}}$ & 㧒 & $\frac{15}{5}$ & 18 & ミ & 范 & 芯 & is & క్ & న్ & 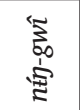 & 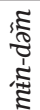 \\
\hline$\frac{y}{\pi}$ & , & 胥 & $\frac{1 \omega}{\sigma}$ & $\omega$ & 忍 & $\frac{\frac{1}{1}}{\sqrt[1]{2}}$ & 'ृ & $\mathbb{L}$ & 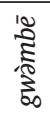 & న్న & 'స్ & 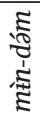 \\
\hline$\sum^{\frac{y}{3}}$ & $\frac{\sqrt[3]{3}}{\sqrt[3]{\infty}}$ & 胥 & is & 'D & : & 范 & ¿ర్ & 17 & క్ & 点 & 㤐兽 & 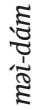 \\
\hline $\begin{array}{l}\text { 可 } \\
\frac{0}{000} \\
\sum \\
\sum\end{array}$ & 范 & 芯: & $i \omega$ & $\&$ & 怘 & $\frac{\sqrt[3]{3}}{\sqrt[3]{2}}$ & "ृु & క్ర & క్ & : & 胥 & $\frac{5}{\frac{5}{8}}$ \\
\hline ?̊ & 'ָּ & $: \approx$ & 深 & $\underbrace{\tilde{z}}$ & 总 & 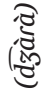 & ¿ี & 恼 & 点 & ह్ & (管 & 疍 \\
\hline صै & 芯 & हี & $\frac{\omega}{i}$ & : & 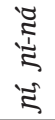 & 悹 & ర్ర & $\underbrace{10}$ & 竞 & న్న & (2) & 灾 \\
\hline 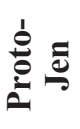 & 﨎 & 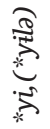 & $\overbrace{*}^{8}$ & $\sum_{*}^{\infty}$ & 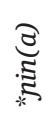 & $\frac{\frac{\mho}{3}}{\frac{3}{*}}$ & 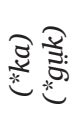 & 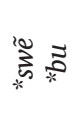 & క్ర & $\underset{*}{\tilde{5}}$ & కై & $\underset{乛}{\mathbb{3}}$ \\
\hline$\frac{n}{0}$ & 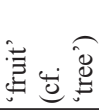 & $\bar{\Xi}$ & $\overbrace{0}^{0}$ & "8 & $\begin{array}{l}8 \\
8 \\
8\end{array}$ & 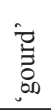 & $\begin{array}{l}n \\
\tilde{w} \\
\tilde{w} \\
0 \\
0\end{array}$ & 焉 & 包 & 苛 & 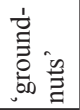 & एా \\
\hline
\end{tabular}




\begin{tabular}{|c|c|c|c|c|c|c|c|c|c|c|c|c|c|}
\hline ঙ̊: & 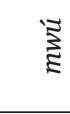 & ('心) & ב & 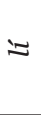 & ఏે & हે & 180 & "R & $\begin{array}{l}0 \\
\vdots \\
0\end{array}$ & 矛 & $i \frac{\pi}{\sigma}$ & క్ & 芯 \\
\hline $\begin{array}{l}\text { ஜ } \\
\text { ஜ }\end{array}$ & 志 & 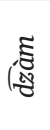 & కై & $\approx$ & 㶓 & '્ & i⿱ & 点 & है & 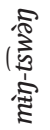 & 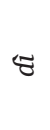 & శี & ( \\
\hline$\underset{E}{\underline{E}}$ & '゙્ & 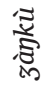 & $\frac{\sqrt[3]{1}}{\frac{1}{0}}$ & : & 怘 & 丞 & 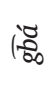 & 8 & है & 跑 & 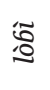 & $\tilde{\sigma}$ & $\mathbf{Z}$ \\
\hline 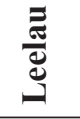 & $\begin{array}{l}\mathfrak{\Xi} \\
\text { : } \\
:\end{array}$ & 蛋 & 10 & 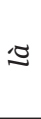 & 疋 & క్ & $\begin{array}{l}\text { శ్ } \\
\text { కి }\end{array}$ & 兽 & "రి & $\stackrel{\overparen{\hat{s}}}{ }$ & $\tilde{\sigma}$ & శ్ & 胥 \\
\hline$\frac{8}{2}$ & 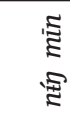 & $\frac{8}{5}$ & ¿ & 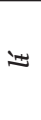 & 'ָָ & ప్ & : & $\stackrel{8}{8}$ & ప్ర & 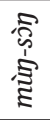 & iv & 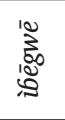 & 胥 \\
\hline $\begin{array}{l}\hat{\pi} \\
\vec{\pi}\end{array}$ & 㣽 & : & : & $\approx$ & 芯 & $\begin{array}{l}\frac{\text { s }}{5} \\
\text { क } \\
\text { है }\end{array}$ & (18) & $\begin{array}{l}\text { ర } \\
\text { हิ } \\
\text { పे }\end{array}$ & है & 疍 & i。 & i & 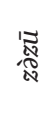 \\
\hline$\sum^{\frac{y}{\tilde{J}}}$ & 谒 & 18 & న్తి & 莕 & ': & 远 & (18) & 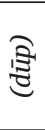 & పे & 蛋 & $\tilde{\sigma}$ & 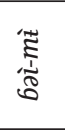 & 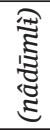 \\
\hline $\begin{array}{l}\text { :5 } \\
\frac{0}{600} \\
\sum^{5}\end{array}$ & 於 & 'ర & 10 & : & కిశ్ర: & 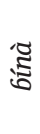 & $\frac{10}{100}$ & हृ & "రి & $\begin{array}{l}\stackrel{\mathfrak{\Phi}}{\overparen{D}} \\
\stackrel{1}{\Xi}\end{array}$ & $\frac{\sqrt[3]{9}}{i \tilde{0}}$ & 8 & 疋 \\
\hline$\stackrel{8}{\stackrel{8}{\epsilon}}$ & 8 & 8 & $\begin{array}{l}\text { ڤે } \\
10\end{array}$ & : & : & : & 路 & 胥 & "రి & '2 & है & 涩 & 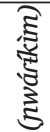 \\
\hline صै & 8 & $\underbrace{8}_{5}$ & $\begin{array}{l}\text { ڤે } \\
\text { ڤે }\end{array}$ & 岂 & 㣽 & 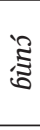 & $\frac{10}{200}$ & $\frac{8}{8}$ & '0 & 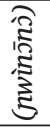 & $\begin{array}{l}\text { w. } \\
\text { పे }\end{array}$ & 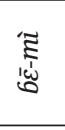 & 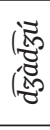 \\
\hline 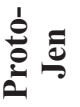 & 疋蛋 & 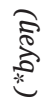 & 을 & $\ddot{*}$ & $(\underset{\mathbb{N}}{\mathbb{Z}} \cdot \overrightarrow{\mathbb{K}}$ & 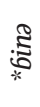 & $\frac{\sqrt{7}}{\frac{\pi}{6}}$ & 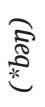 & ฟิ & 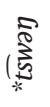 & $\underset{*}{*}$ & ๘ँ & 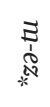 \\
\hline$\frac{n}{0}$ & Ð & : & $\stackrel{\mathbb{\mathscr { J }}}{=} \overline{0}$ & : & $\underset{\Xi}{\mathbb{Z}}$ & $\sum_{\tilde{J}}^{\mathrm{E}}$ & 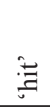 & $\stackrel{8}{\square}$ & 응 & త్ & ఏ్త & 占 & 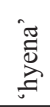 \\
\hline
\end{tabular}




\begin{tabular}{|c|c|c|c|c|c|c|c|c|c|c|c|c|}
\hline$\stackrel{\text { ஸี }}{0}$ & $\therefore$ & $\stackrel{2}{i}$ & $\frac{\sqrt[5]{5}}{\left(\frac{\sqrt{0}}{8}\right.}$ & 'ָ & $: \approx$ & ' & : & '̊ี & 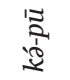 & 3ั & 通 & 'న: \\
\hline $\begin{array}{l}\text { ஜ } \\
\stackrel{\circ}{\circ}\end{array}$ & $\therefore$ & : & $\frac{\sqrt{5}}{3}$ & 点 & 行 & 㣽 & $\stackrel{2}{\frac{9}{1}}$ & $\hat{\Xi}$ & $\frac{3}{3}$ & ఏે & $\stackrel{2}{\curvearrowleft}$ & : \\
\hline$\underset{E}{E}$ & 8 & 苂 & 孞 & "D & 浞 & : $: \mathbb{Z}$ & : & $\stackrel{\overbrace{}}{\mathbf{I}}$ & $\begin{array}{l}3 \\
3 \\
3 \\
3 \\
3\end{array}$ & స్తి & 痣 & 壳 \\
\hline 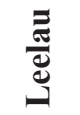 & ๙্ণি & 䇛 & 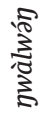 & $\begin{array}{l}\text { కే } \\
\text { స్ట }\end{array}$ & $\begin{array}{l}\tilde{\pi} \\
\tilde{2}\end{array}$ & : & : & $\stackrel{\widetilde{\Xi}}{\Xi}$ & ¿ & $\begin{array}{l}\text { ' } \\
\text { के } \\
: 0\end{array}$ & 雱 & 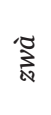 \\
\hline$\frac{8}{2}$ & ঙ্ণি & 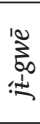 & 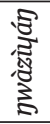 & हٓ & 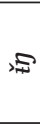 & 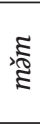 & $\stackrel{乛}{\Omega}$ & 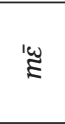 & 18 & ?0 & श्र & 怘 \\
\hline 光 & 胥 & 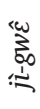 & 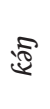 & $\begin{array}{l}\text { స్ } \\
\text { ड్ }\end{array}$ & $\sim$ & ఏ & กั & 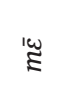 & $\begin{array}{l}\frac{\mho}{0} \\
10\end{array}$ & 으 & 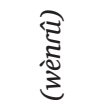 & 'ర్: \\
\hline$\frac{\text { है }}{\sum}$ & $\frac{10}{3}$ & 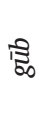 & 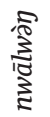 & శิ & 'ָ & : & : & ' & 18 & 'ָּ & $\frac{\pi}{\frac{\pi}{0}}$ & 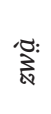 \\
\hline $\begin{array}{l}\frac{5}{0} \\
\frac{\pi}{00} \\
\sum\end{array}$ & $\begin{array}{l}\text { క } \\
3\end{array}$ & న్రి: & 范 & ఠิ & 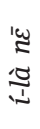 & 点 & $\stackrel{\overbrace{}}{\stackrel{\Omega}{\Omega}}$ & 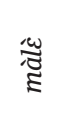 & 'o: & శ్ర & $\frac{10}{\sqrt{0}}$ & 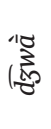 \\
\hline$\stackrel{8}{\stackrel{0}{\varrho}}$ & $\frac{10}{3}$ & 趈 & 苛 & $\stackrel{2}{\overparen{D}}$ & $\underbrace{i n}_{\underbrace{\omega}}$ & ఏ & : & ? & '0: & ఏ & 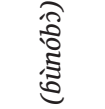 & 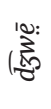 \\
\hline है & :̊ & క్రి & : & $\stackrel{2}{2}$ & '. & ఏ స్ & : & ' & 'O: & స్త & $\frac{0}{0}$ & 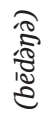 \\
\hline 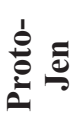 & $\begin{array}{l}\frac{\sqrt{10}}{2} \\
\frac{2}{*} \\
\frac{2}{*}\end{array}$ & ఏ్రి: & $\sum_{*}^{\infty}$ & है & $\tilde{*}$ & : & న్ & $\stackrel{E}{*}_{*}^{\omega}$ & : & '앛 & $\sum_{*}^{0}$ & 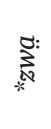 \\
\hline$\frac{\tilde{c}}{0}$ & $\overline{\bar{z}}$ & 每 & 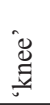 & 导 & 蒙 & & 离 & $\stackrel{\frac{\partial}{0}}{\frac{\pi}{0}}$ & की & 气 & 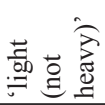 & $\stackrel{\tilde{0}}{=}$ \\
\hline
\end{tabular}




\begin{tabular}{|c|c|c|c|c|c|c|c|c|c|c|c|c|}
\hline ̊ั & $\frac{\sqrt{3}}{\sqrt[i]{2}}$ & 揟 & $\begin{array}{l}\frac{1}{n} \\
\frac{1}{5} \\
\frac{3}{8}\end{array}$ & 虾 & $\sum_{i}^{\omega}$ & 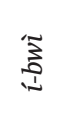 & 胥 & $\because[0$ & $\tilde{0}$ & 'Z̃ & ": & (") \\
\hline ஜ̂̊ & $\sqrt[Z]{2}$ & 㣽 & 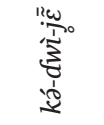 & $\frac{10}{12 \frac{1}{\beth}}$ & $\frac{n}{\frac{1 \omega}{2}}$ & 吝 & 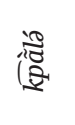 & 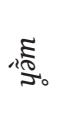 & $\tilde{\sigma}$ & $\hat{Z}$ & 念。 & 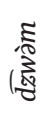 \\
\hline$\stackrel{\text { }}{E}$ & 高 & $\hat{\Xi}$ & 渎 & 吝 & 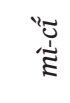 & 芯 & 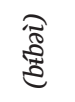 & 'ミ & కิ & 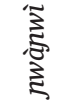 & 近 & 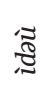 \\
\hline 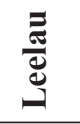 & 厄) & $\stackrel{\mathfrak{Z}}{ }$ & $\begin{array}{l}\frac{3}{3} \\
\frac{3}{3}\end{array}$ & 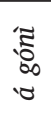 & 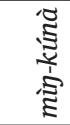 & 芯 & 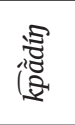 & . స్ & हิ & $\ddot{\Sigma}$ & \& & 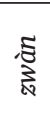 \\
\hline$\frac{8}{2}$ & అ & '̇ & $\frac{\sqrt[3]{3}}{\frac{3}{3}}$ & పे & 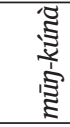 & 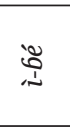 & (") & 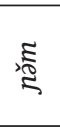 & క气 & ¿̊̃ & is & క్ \\
\hline 艺 & 这 & 㞼 & ड़े & $\begin{array}{l}\text { 岕 } \\
\text { పे }\end{array}$ & 莹 & 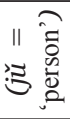 & 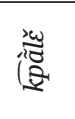 & $\stackrel{2}{2}$ & อิ & 污 & \& & సิ \\
\hline$\sum^{\frac{y}{*}}$ & $\begin{array}{l}\text { 深 } \\
\text { 范 }\end{array}$ & $\ddot{\Xi}$ & 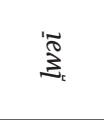 & 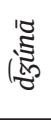 & 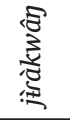 & $\frac{\tilde{\sigma}}{i}$ & 茎 & : & $\approx$ & 污 & $\tilde{z}$ & 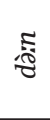 \\
\hline 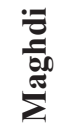 & 芯 & 䏠 & ఏే & 总 & 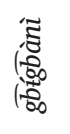 & $\frac{\tilde{\sigma}}{i d}$ & శ్రి & : & 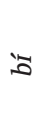 & '乏̃ & 范 & :ే \\
\hline$\stackrel{8}{\stackrel{0}{\rho}}$ & $\frac{3}{3}$ & $\tilde{\Xi}$ & 恚 & 溚 & $\begin{array}{l}\stackrel{8}{ } \\
\text { : }\end{array}$ & 蒂 & 兽兽 & . & క్రి & Zz & $\widetilde{\Sigma}$ & : \\
\hline 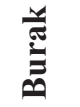 & 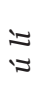 & ' & 岕 & 岕 & 总 & $\begin{array}{l}10 \\
0 \\
i\end{array}$ & $\stackrel{\text { ङ }}{3}$ & : & $\Xi$ & $\tilde{Z}$ & $\vec{\Omega}$ & $\sqrt[5]{5}$ \\
\hline 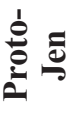 & 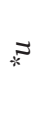 & $\tilde{*}$ & $\sum_{*}^{0}$ & 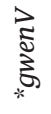 & 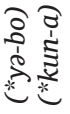 & 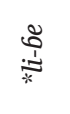 & 跑 & న్ & $\tilde{*}$ & 汸 & $\tilde{R}$ & 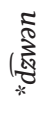 \\
\hline$\frac{n}{0}$ & i) & $\stackrel{\dot{0}}{\vdots}$ & 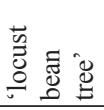 & on & 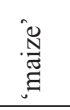 & ‡ี & ઊ્ટ & ఏ్ర & 吾 & 咅总 & 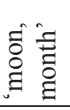 & 营 \\
\hline
\end{tabular}




\begin{tabular}{|c|c|c|c|c|c|c|c|c|c|c|c|c|}
\hline กี & i & 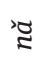 & స్ & స్తి & $\check{\Omega}$ & 殸 & 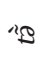 & "8 & 等: & $\frac{\Xi}{\infty}$ & 怘 & 孛 \\
\hline $\begin{array}{l}\text { ஜ } \\
\text { ह̊ } \\
0\end{array}$ & '。' & '气 & స్ర & 苚 & ' $\tilde{a}$ & 逭 & $B$ & 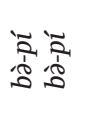 & 点 & $\underset{⿱ 乛}{\mathbb{2}}$ & 胥 & $\begin{array}{l}\widetilde{3} \\
\frac{3}{1} \\
\text { sे } \\
\text { bे }\end{array}$ \\
\hline 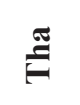 & : & ' & 䓢 & 零 & 18 & ":శี & 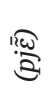 & $\begin{array}{l}: \omega \\
0 \\
1 \\
0 \\
0\end{array}$ & 瓷 & $\underset{\sim}{2}$ & 帘 & 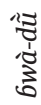 \\
\hline 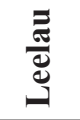 & : & 'Z & 'ే & $\begin{array}{l}\frac{\pi}{2} \\
\text { s్ర }\end{array}$ & $\tilde{\Omega}$ & $\mathfrak{\Xi}$ & 吕 & 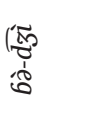 & శ్ & $\frac{i \overrightarrow{2}}{\sigma}$ & "5 & 迅 \\
\hline$\stackrel{8}{\Sigma}$ & : & $\stackrel{2}{Z}$ & 勇 & $\begin{array}{l}\text { శి } \\
\text { స్ట }\end{array}$ & $\check{\imath}$ & 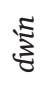 & శి & 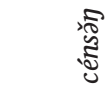 & $\mathbb{Z}$ & $\underbrace{i}_{\sigma}$ & 㢳 & 语 \\
\hline$\frac{y}{\pi}$ & : & $\stackrel{\leftrightarrow \omega}{\Xi}$ & 芯 & స్లి & $\tilde{\Omega}$ & $\underbrace{5}$ & \$ి & న్ర & $\mathbb{Z}$ & $\underbrace{i}_{\infty}$ & 5 & i্ত \\
\hline$\sum^{\frac{y}{E}}$ & 'ల్ & 'రి: & 'ర્ટ': & ఫే & $\frac{\pi}{6}$ & 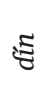 & 㣽 & 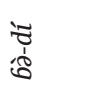 & $\mathbb{\mathfrak { Z }}$ & 宾 & 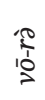 & 谞 \\
\hline $\begin{array}{l}\frac{5}{0} \\
\frac{0}{000} \\
\sum \\
\sum\end{array}$ & 'ฮี & ב & ఏે & గి & '‡, & 占 & 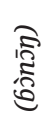 & 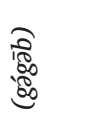 & : & $\sum_{0}^{2}$ & : & 洁 \\
\hline$\stackrel{8}{9}$ & $\ddot{\omega}$ & 'Zz & ఏ & :ి & $\frac{\pi}{\omega}$ & 迅 & 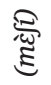 & '气 & $\mathbb{\mathbb { Z }}$ & $\frac{\sqrt[3]{2}}{\sqrt[3]{2}}$ & 岕 & '5 \\
\hline صै & i⿱⺌兀⿱一兀 & 'Z & 'రీ: & : & 岕 & 点 & 荵 & '‡. & : & $\frac{\sqrt{3}}{\sqrt[3]{5:}}$ & $\stackrel{\omega}{\omega}$ & '5 \\
\hline 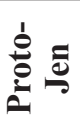 & $\overbrace{*}^{\sigma}$ & : & $\sum_{*}^{\tilde{J}}$ & 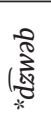 & 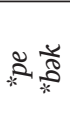 & 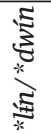 & 荵 & 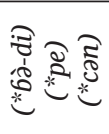 & $\mathbb{Z}$ & $\underset{*}{2}$ & $\stackrel{2}{*}$ & 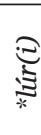 \\
\hline$\frac{\tilde{c}}{0}$ & 官 ”。 & 㐫 & 吾 & $\bar{\Xi}$ & $\bar{\Xi} \overparen{\Xi}$ & 导 & 咅 & 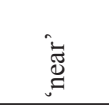 & 过 & 运 & .0.0 & : \\
\hline
\end{tabular}




\begin{tabular}{|c|c|c|c|c|c|c|c|c|c|c|c|}
\hline ลี & '્હ & 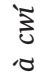 & 18 & 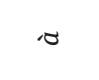 & 痣 & 岕 & $\begin{array}{l}\text { 总 } \\
\text { 兽 }\end{array}$ & $\stackrel{8}{8}$ & 4 & 资 & '2 \\
\hline ஜ̊̊̆ & 胥 & $\begin{array}{l}\text { ș } \\
\text { 心 }\end{array}$ & $\tilde{8}$ & $\tilde{8}$ & 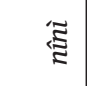 & : & 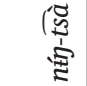 & $\stackrel{\text { శ్ }}{\text { 今్ర }}$ & ' & $\mathbb{Z}$ & r \\
\hline$\stackrel{\Xi}{E}$ & 胥 & 峁 & 8 & 8 & 敢 & 胥 & 8 & $\frac{3}{\frac{3}{3}}$ & క్ర & $\Xi$ & $\therefore$ \\
\hline 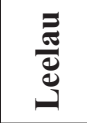 & ’ & $\frac{0}{\pi}$ & $\widetilde{\Xi}$ & $\widetilde{\Xi}$ & ': & $: \cong$ & 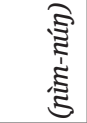 & 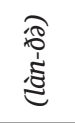 & క్టి & : & 范 \\
\hline$\stackrel{8}{\stackrel{g}{2}}$ & '气 & 丑 & 18 & ن' & 况 & $: \cong$ & $\begin{array}{l}\text { 雨 } \\
\text { 蛋 }\end{array}$ & 恚 & క్టి & : & 范 \\
\hline 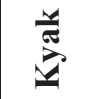 & ' & $\frac{12}{0}$ & 8 & D & 㣽 & $: \cong$ & $\begin{array}{l}\text { 㴓 } \\
\text { 害 }\end{array}$ & $\frac{\sqrt[5]{5}}{\left(\frac{\omega}{\omega}\right.}$ & 茄 & : & 茨 \\
\hline 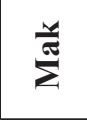 & 空 & 资 & 8 & 8 & '官 & 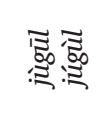 & 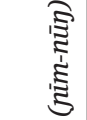 & 'ే & క్టి & 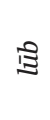 & 范 \\
\hline 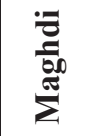 & : & i⿱ & "శ్రి & "శ్రి & $\tilde{\sigma}$ & 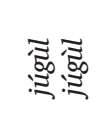 & $\mathbb{8}$ & $\check{\Xi}$ & క్రి & : & 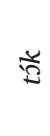 \\
\hline$\stackrel{8}{9}$ & 胥 & 虫 & 8 & 8 & $\tilde{\Xi}$ & $\Xi$ & 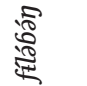 & $\tilde{\Xi}$ & : & : & 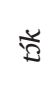 \\
\hline 荷 & 胥 & 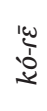 & 8 & : & $\tilde{\Xi}$ & $\Xi$ & $\begin{array}{l}\frac{\sqrt{0}}{10} \\
\check{\Sigma}\end{array}$ & ' $\omega$ & క్రి: & 跬 & 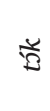 \\
\hline 递 휼 & 芯 & $\frac{\rho}{*}$ & 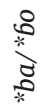 & $\approx$ & 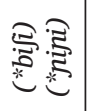 & 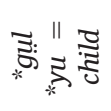 & 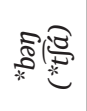 & 浐 & కే: & క & $\stackrel{v}{s}$ \\
\hline$\frac{n}{0}$ & $\bar{\nabla}$ & $\frac{\pi}{0}$ & ठั. & 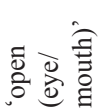 & है & 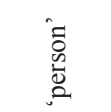 & $\frac{\vec{a}}{2}$ & 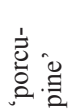 & $\overline{\bar{z}}$ & $\begin{array}{l}\stackrel{\varrho}{\Xi} \\
\bar{\Xi}\end{array}$ & $\begin{array}{l}\overline{\tilde{n}} \\
\overline{\tilde{n}} \\
\bar{z}\end{array}$ \\
\hline
\end{tabular}




\begin{tabular}{|c|c|c|c|c|c|c|c|c|c|c|c|}
\hline กี & ' & $\frac{\ll}{w}$ & 尽 & $! \omega$ & iర్ల & : & $<$ & $\overbrace{}^{\circledR}$ & 沽。 & $\stackrel{2}{2}$ & $\approx$ \\
\hline ஜூ & $\hat{\Xi}$ & 造 & 尽 & ? & "ర్ల & : & 蛋 & $\begin{array}{l}\text { న } \\
\text { 今 }\end{array}$ & 畧 & 䓌 & $\tilde{\delta}$ \\
\hline$\stackrel{\Xi}{E}$ & ఏ్ & : & $\begin{array}{l}\text { 尽 } \\
\text { 忠 }\end{array}$ & W & "E & i̊ & 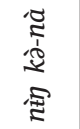 & ฐ & 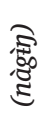 & $\because \approx$ & $\tilde{\pi}$ \\
\hline 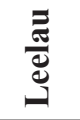 & 兽 & 怘 & 袁 & 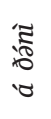 & 兽 & : & 羕 & $\begin{array}{l}\tilde{z} \\
\text { శ్ }\end{array}$ & $\frac{\tilde{\Xi}}{\mathfrak{\Xi}}$ & हีّ & $\pi$ \\
\hline$\frac{8}{2}$ & હે & 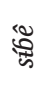 & ミ & $\underset{\mathbb{N}}{\mathbb{E}}$ & 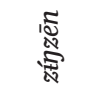 & 证 & $\frac{\sqrt[2]{2}}{\frac{1}{2}}$ & 点 & $\frac{\omega}{2}$ & $\frac{\sqrt[3]{3}}{\sqrt[9]{9}}$ & $\pi$ \\
\hline$\frac{y}{\pi}$ & હે & 必 & IZ & $\underset{N}{1 ీ ్ ట ్ ~}$ & i & : & 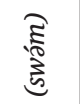 & $\underset{\frac{\pi}{3}}{\frac{\pi}{\infty}}$ & I & 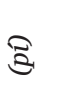 & $\tilde{\nabla}$ \\
\hline$\sum^{\frac{y}{E}}$ & $\stackrel{\prime}{ } \mathbf{\Xi}$ & 兽 & $\stackrel{\mathfrak{Z}}{\mathbf{E}}$ & 於 & ड़े & 路 & $\frac{\sqrt[3]{3}}{\sqrt[3]{Z}}$ & 点 & 胥 & $: \stackrel{\Omega}{\Omega}$ & $\pi$ \\
\hline $\begin{array}{l}\text { :5 } \\
\frac{5}{600} \\
\sum \\
\sum\end{array}$ & $\stackrel{\mathfrak{\Xi}}{ }$ & 畧 & ' & 记 & $\begin{array}{l}10 \\
12 \\
2\end{array}$ & 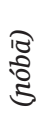 & $\mathfrak{Z}$ & 点 & : & $: \stackrel{0}{\Omega}$ & $\sqrt[\pi]{0}$ \\
\hline$\stackrel{9}{9}$ & 点 & હ્ડ & 'w: & 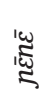 & (志 & : & 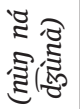 & $\stackrel{2}{\mathbb{Z}}$ & : & हैँ & $\sqrt{8}$ \\
\hline 气ี & ' $\Xi$ & 㤀 & 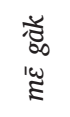 & 贞 & 点 & : & 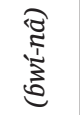 & 占 & : & 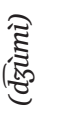 & $\widetilde{\nabla}$ \\
\hline 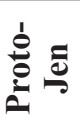 & $\vec{E}$ & 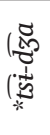 & : & $\underbrace{\tilde{W}}_{*}$ & 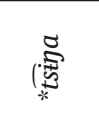 & $\frac{\pi}{*}$ & $\frac{\pi}{*}$ & 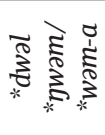 & $\frac{\omega}{*}$ & 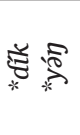 & $\underset{\mathscr{\sigma}}{\mathscr{0}}$ \\
\hline$\frac{n}{0}$ & 氞 & : & $\underbrace{\|}_{0}$ & ¿ृ. & 己. & 离 & $\stackrel{30}{\Xi}$ & $\stackrel{\bar{J}}{:}$ & : & 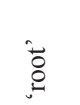 & :ै \\
\hline
\end{tabular}




\begin{tabular}{|c|c|c|c|c|c|c|c|c|c|c|}
\hline$\stackrel{\text { İ }}{0}$ & '宗。 & ᄅै & 'ミ゙ & 梁 & : 2.5. & 孞 & 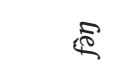 & "ర & 8 & 䆓 \\
\hline 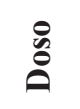 & 'న' & 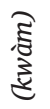 & $\mathbb{L}$ & 偊 & 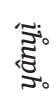 & $\frac{\overparen{Z}}{\frac{\nabla}{\mathbb{Z}}}$ & 䠃 & 令 & 8 & 㣽 \\
\hline$\stackrel{\Xi}{E}$ & : & ऐँ & 识 & క气 & 话 & 彺 & 18 & 忐 & $\tilde{\theta}$ & 宋 \\
\hline 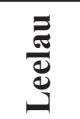 & $\widetilde{d}$ & 跑 & 说 & $\tilde{乛}$ & 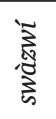 & $\tilde{\Phi}_{0}$ & $\frac{\sqrt{2}}{\frac{1}{2}}$ & $\frac{\sqrt{2}}{\frac{1}{2}}$ & 经 & : \\
\hline$\frac{8}{2}$ & $\begin{array}{l}\text { 灾 } \\
\text { 心 } \\
\text { 心 }\end{array}$ & 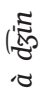 & 'ミ゙ & $\frac{10}{8}$ & 'ָ & $\begin{array}{l}10 \\
i \\
0\end{array}$ & 3 & 还 & ĩ & 帘 \\
\hline$\underset{2}{\frac{y}{2}}$ & 录 & 空 & 识 & $\frac{10}{8}$ & 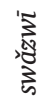 & is & $\underbrace{n \omega}$ & "ర్ & $\tilde{\sigma}$ & 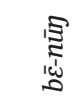 \\
\hline$\sum^{\frac{\pi}{5}}$ & 点 & 胥 & 㤀 & $\tilde{\mathbb{8}}$ & $\begin{array}{l}10 \\
\text { 壳 } \\
\text { 今े } \\
\text { के }\end{array}$ & $\tilde{8}$ & 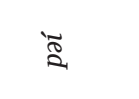 & $\stackrel{\widetilde{\Omega}}{\stackrel{6}{6}}$ & $\stackrel{乛}{0}$ & כै \\
\hline 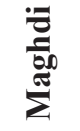 & 总 & 荋 & $\stackrel{\theta}{0}$ & $\tilde{\tilde{\theta}}$ & 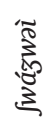 & id: & 'నొ & 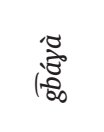 & న્ટ & 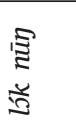 \\
\hline 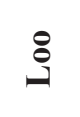 & 离 & $\underbrace{80}_{0}$ & $\underbrace{\frac{9}{\pi}}$ & '0: & 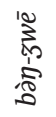 & '\$ & 览 & $\begin{array}{l}\frac{2}{3} \\
\frac{3}{3} \\
10\end{array}$ & $\stackrel{乛}{2}$ & $\begin{array}{l}\text { : } \\
\text { : } \\
\text { : }\end{array}$ \\
\hline 气ี & 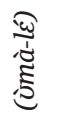 & 悹 & $\frac{\square}{\sqrt[\square]{0}}$ & $\frac{1 \omega}{\sigma}$ & $\begin{array}{l}10: \\
\text { 岕 } \\
\vdots \\
3 \\
3\end{array}$ & 's: & 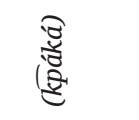 & ?્తి & 'ঙ & $\begin{array}{l}\stackrel{\Xi}{\vdots} \\
\frac{1}{2}\end{array}$ \\
\hline 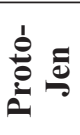 & : & $\underset{*}{\circledast}$ & 瓦㣽志 & $\frac{\mathbb{x}}{*}$ & 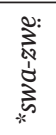 & $\underset{*}{8}$ & 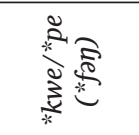 & 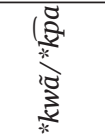 & ๙ิ & 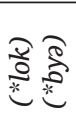 \\
\hline$\frac{n}{0}$ & $\overbrace{0}^{0}$ & $\begin{array}{l}\overline{\vec{z}} \\
\bar{\Xi} \\
\overline{0}\end{array}$ & 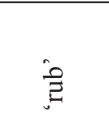 & $\frac{\vec{I}}{\tilde{B}}$ & 胥 & 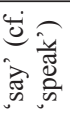 & 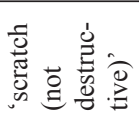 & 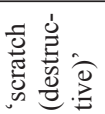 & is & 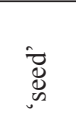 \\
\hline
\end{tabular}




\begin{tabular}{|c|c|c|c|c|c|c|c|c|c|c|c|c|}
\hline$\stackrel{\text { N }}{0}$ & $\frac{\sqrt{2}}{\sqrt[3]{3}}$ & $?$ & $\frac{\mathfrak{3}}{\mathfrak{3}}$ & $\therefore$ & (3) & 站 & "I & 'ZZ & 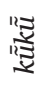 & $\underset{0}{0}$ & $\begin{array}{l}\sqrt[3]{2} \\
\sqrt[3]{8}\end{array}$ & 13 \\
\hline $\begin{array}{l}\text { ஜ } \\
\text { ह̊ } \\
0\end{array}$ & 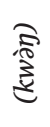 & $\stackrel{\widetilde{\pi}}{8}$ & 莃 & : & 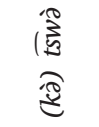 & م. & 㣽 & ' & 胥 & 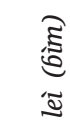 & 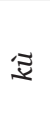 & (3) \\
\hline$\stackrel{\Xi}{E}$ & 里 & '心 & 荵 & $\stackrel{10}{\approx}$ & $\frac{\sqrt[3]{3}}{\sqrt[3]{3}}$ & “你 & 沉 & 'Z & 忐 & 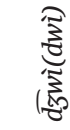 & $\frac{3}{3}$ & . \\
\hline 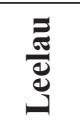 & 尽 & 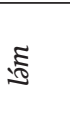 & $\frac{\sqrt[3]{0}}{3}$ & 㤐 & 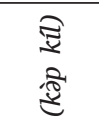 & ฐ్ & "న్ర & '心 & 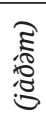 & 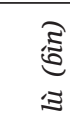 & $\underbrace{0}_{0}$ & 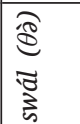 \\
\hline$\frac{8}{2}$ & $\begin{array}{l}\sqrt{\sqrt[2]{2}} \\
\frac{3}{3} \\
\frac{3}{2}\end{array}$ & 孯 & $\frac{\mathfrak{Z}}{3}$ & 㤐送 & 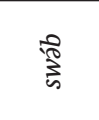 & 离 & חi & 'ZZ & 荵 & \begin{tabular}{l} 
这 \\
\multirow{2}{\Xi}{}
\end{tabular} & 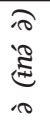 & ) \\
\hline$\frac{y}{\pi}$ & 㣽 & క్ర & $\frac{\sqrt[3]{7}}{\mathfrak{n}}$ & हే & 点 & 胥 & חי & ' & 胥 & 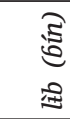 & $\underbrace{Ð 0}_{\infty}$ & $\begin{array}{l}\text { त्र } \\
\text { इे }\end{array}$ \\
\hline$\sum^{\frac{y}{3}}$ & 买 & हิ & 这 & :્ટ્ટ & $\begin{array}{l}\text { हీ } \\
\text { ప్ర }\end{array}$ & $\begin{array}{l}\text { : } \\
\text { : }\end{array}$ & 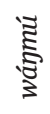 & 'Z & 胥 & 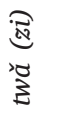 & $\frac{3}{103}$ & 足 \\
\hline 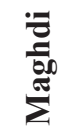 & 迟 & $\frac{\mathfrak{s}}{\frac{5}{w}}$ & 选 & ?) & క్రి & $\begin{array}{l}\text { శิ } \\
\frac{1}{0}\end{array}$ & 疋 & 'ZZ & $\frac{\sqrt[3]{\pi}}{\sqrt[7]{80}}$ & 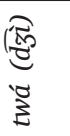 & క & $\frac{\widetilde{\pi}}{\pi}$ \\
\hline 용 & 㣽 & 胥 & 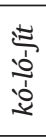 & 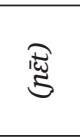 & 胥 & 令 & 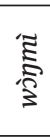 & 'ZZ & 迅 & 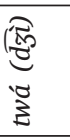 & $\begin{array}{l}3 \\
3 \\
3 \\
3 \\
3 \\
3\end{array}$ & $\frac{\pi}{\sqrt[3]{3}}$ \\
\hline 气ี & 㣽 & 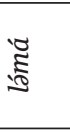 & $\frac{\sqrt[N]{1}}{\frac{i}{3}}$ & 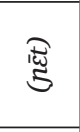 & త్రీ & 令 & 点 & 'ZZ & 'క్ర & 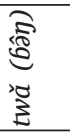 & $: Z$ & $\widetilde{D}$ \\
\hline 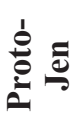 & $\underset{*}{\stackrel{\mathbb{N}}{*}}$ & 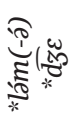 & 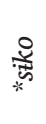 & हิ & $\underbrace{\frac{\pi}{*}}_{*}$ & 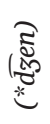 & 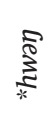 & $\underset{*}{\mathbb{Z}}$ & $\frac{\sqrt{\mathbb{N}}}{*}$ & 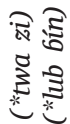 & $\vec{*}$ & 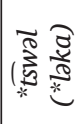 \\
\hline$\frac{\hat{0}}{0}$ & 竞 & 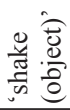 & 导 & 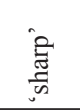 & 导 冚 & $\frac{\overline{0}}{\frac{0}{7}}$ & $\frac{8}{0}$ & $\frac{0}{0}$ & $\frac{\pi}{5}$ & .jo & : & 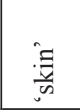 \\
\hline
\end{tabular}




\begin{tabular}{|c|c|c|c|c|c|c|c|c|c|c|c|c|}
\hline ลี & 突 & 恣 & હ & 'కా。 & 'ง & l'o: & 's & 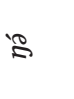 & હ & క్ & 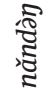 & 淰 \\
\hline $\begin{array}{l}\stackrel{\mathscr{n}}{0} \\
\stackrel{0}{0}\end{array}$ & 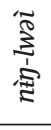 & 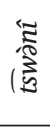 & 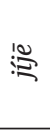 & 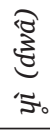 & '? & 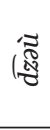 & ' & క్రి & હ & 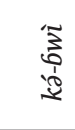 & 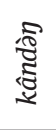 & 㑫 \\
\hline$\stackrel{\Xi}{E}$ & 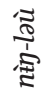 & $\begin{array}{l}: \mathbb{8} \\
\circ\end{array}$ & : & 湑 & 象 & శ్ర & శ్ర & $\widetilde{\widetilde{D}}$ & 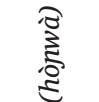 & క్ & ' & 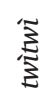 \\
\hline 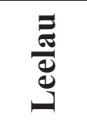 & 总 & $\begin{array}{l}\text { 今 } \\
\text { పે } \\
\text { ' }\end{array}$ & 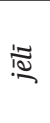 & $\mathfrak{Z}$ & है & !̋ & $\begin{array}{l}\text { : } \\
\text { है }\end{array}$ & 莕 & $\tilde{\delta}$ & 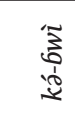 & $\begin{array}{l}\text { : } \\
\text { క్రే }\end{array}$ & 恁 \\
\hline$\stackrel{8}{\Sigma}$ & 总 & $\begin{array}{l}\text { న్న } \\
\mathbb{N} \\
\mathbb{5}\end{array}$ & 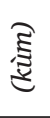 & (: & 证 & : & $\stackrel{0}{3}$ & हే & $\begin{array}{l}180 \\
\stackrel{1}{8} \\
\frac{8}{8}\end{array}$ & है & 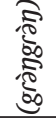 & 儚 \\
\hline$\underset{\vec{z}}{\stackrel{y}{*}}$ & 总 & 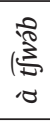 & $\underset{\pi}{\sim}$ & (జ⿱乛ే) & डે & 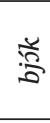 & ’ & న్ & $i^{1} \otimes$ & 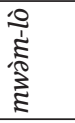 & 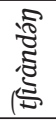 & 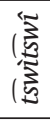 \\
\hline$\frac{\text { जै }}{\Sigma}$ & $\frac{\widetilde{\pi}}{\stackrel{3}{5}}$ & 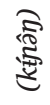 & હీ & $\mathfrak{Z}$ & is & 艿 & 蛋 & ' & $\tilde{\varepsilon}$ & 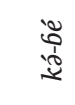 & 荵 & 空 \\
\hline 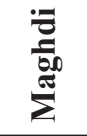 & 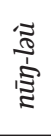 & శ్వి & : & 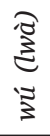 & i & 茖 & 疍 & 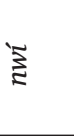 & i & . స్ & 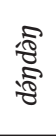 & 沗 \\
\hline ְְ & $\frac{\sqrt[3]{3}}{\frac{\pi}{5}}$ & శ్వి & 恚 & ' & ₹్రิ & 艿 & 导 & 穾 & 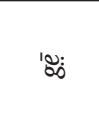 & : & 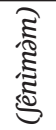 & 芑 \\
\hline 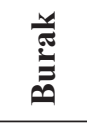 & 蔦 & 菅 & 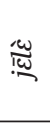 & 'ב: & $\widehat{\hat{\Xi}}$ & 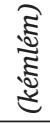 & 㤀 & 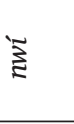 & '\&: & ટ્ડ & 胥 & בे \\
\hline 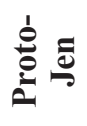 & $\stackrel{0}{*}$ & (5్లో & $\underset{*}{*}$ & \begin{tabular}{l}
$\sum_{*}^{2}$ \\
\multirow{2}{*}{} \\
$*$
\end{tabular} & 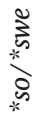 & ङ & $\sqrt[\frac{2}{2}]{2}$ & 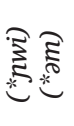 & \%: & है & $\underset{乛}{\overparen{8}}$ & 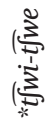 \\
\hline$\frac{\tilde{o}}{0}$ & $\frac{\overline{0}}{u^{n}}$ & 言 & $\begin{array}{l}\overline{\bar{\Xi}} \\
\Xi_{5}\end{array}$ & 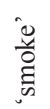 & $\begin{array}{l}\overline{\bar{\sigma}} \\
\overline{5} \\
\overline{5}\end{array}$ & 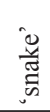 & 今े & 言 & 总 & क्षँّ & 节 & \\
\hline
\end{tabular}




\begin{tabular}{|c|c|c|c|c|c|c|c|c|c|c|c|}
\hline$\stackrel{\mathfrak{N}}{\hat{0}}$ & "范 & 淄 & $\approx$ & l芯 & 苞 & $\frac{5}{3}$ & $\stackrel{2}{2}$ & ידי & \& & ' & $\frac{\sqrt[3]{3}}{\frac{\pi}{\sqrt[3]{3}}}$ \\
\hline ஜ & 点 & 辂 & $\widetilde{\Xi}$ & (זָه & 愘 & $\frac{\sqrt{3}}{3}$ & $\widehat{\widetilde{s}}$ & is & \& & ' & 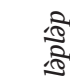 \\
\hline$\stackrel{\Xi}{E}$ & 'ర్త & 位 & 3 & & 黑 & ड़े & $\tilde{\Phi}$ & 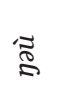 & 造 & ' & 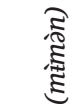 \\
\hline 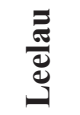 & $\stackrel{8}{8}$ & 昰 & $\tilde{s}$ & $\frac{10}{8}$ & 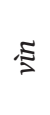 & $\frac{\text { की }}{\text { ह }}$ & శ్రి & ह & 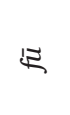 & ' & 恚 \\
\hline$\frac{8}{2}$ & $\begin{array}{l}\sqrt{\infty} \\
\infty\end{array}$ & 蛋 & $\stackrel{n}{2}$ & $\frac{1 \omega}{\sigma}$ & 滈 & $\frac{5}{5}$ & శ్ర & $\therefore$ & 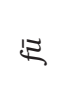 & ‘ & $\frac{\text { : }}{\frac{10}{30}}$ \\
\hline$\frac{v}{\pi}$ & శ్లి & 辂 & $\stackrel{1 \omega}{0}$ & $\frac{1 \omega}{\sigma}$ & 点 & $\frac{\sqrt[5]{3}}{\frac{3}{3}}$ & $\widetilde{B}$ & న & 设 & 'हี & $\frac{\sqrt{3}}{\frac{10}{3}}$ \\
\hline है & 施 & 跑 & 18 & 'ే̊: & Iิ & 胥 & $\widetilde{\Xi}$ & iశ్ & હ্ঠ & ' & 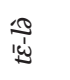 \\
\hline $\begin{array}{l}\frac{5}{0} \\
\frac{\pi}{00} \\
\sum\end{array}$ & 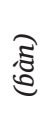 & 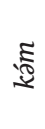 & 18 & శ్శ: & 1ీ & $\frac{\sqrt{2}}{\sqrt[2]{3}}$ & $\widetilde{్}$ & 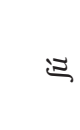 & 党 & 'ह & $\check{\nexists}$ \\
\hline$\stackrel{8}{\ominus}$ & 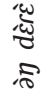 & 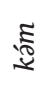 & $\underset{0}{\pi}$ & '요 & 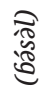 & 胥 & శ్ర & छ & $\tilde{8}$ & ' & 10 \\
\hline صै & $\approx$ & 鸹 & 岕 & '요 & $\frac{2}{\sqrt[20]{20}}$ & 胥 & $\widetilde{్}$ & 结 & $\sqrt{\omega} \omega$ & 'ミ & छี \\
\hline 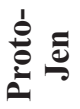 & $\underset{*}{\overparen{R}}$ & $\frac{\tilde{\Phi}}{\frac{\pi}{*}}$ & 8 & : & 尔 & $\frac{\sqrt[3]{2}}{\frac{\pi}{2}}$ & $\vec{p}$ & 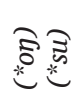 & $\sum_{*}^{2}$ & $\vec{\xi}$ & 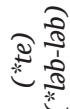 \\
\hline$\frac{\hat{0}}{0}$ & $\frac{\pi}{n}$ & 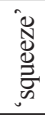 & 薷 & 䓌 & 蓠 & 苍 & 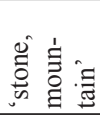 & $\frac{\tilde{y}}{0}$ & 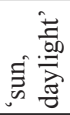 & $\sum_{0}^{1}$ & 峁 \\
\hline
\end{tabular}




\begin{tabular}{|c|c|c|c|c|c|c|c|c|c|c|c|c|}
\hline$\stackrel{\text { న }}{\text { }}$ & $\frac{\frac{1}{3}}{\frac{1}{3}}$ & $\stackrel{\varpi}{\Sigma}$ & 予 & : & 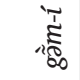 & $\widehat{\Omega}$ & 昘 & veu & 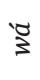 & 若 & $1 \%$ & 菭 \\
\hline $\begin{array}{l}\text { ஜ } \\
\text { ஜ̊ }\end{array}$ & 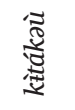 & $\tilde{\Xi}$ & 定。 & 's & 㣽 & : & $\begin{array}{l}\text { 愺 } \\
\text { 里 }\end{array}$ & 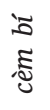 & ఏ & : శ్ర & 13 & 盓 \\
\hline 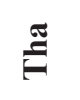 & 总 & (5) & $\begin{array}{l}\text { 雳 } \\
\text { 赵 }\end{array}$ & 结 & 范 & 趈 & 尽 & 跑 & ' & $\sum_{\infty}^{10}$ & 'ర్త & '0 \\
\hline 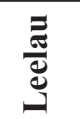 & 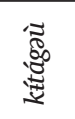 & 沉 & 㴗 & $\tilde{\Xi}$ & 奈 & 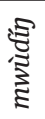 & ミ & $\begin{array}{l}0 \\
0 \\
0 \\
0 \\
0 \\
0\end{array}$ & $\stackrel{10}{3}$ & 孞 & ని & 总 \\
\hline$\frac{8}{2}$ & $\frac{\sqrt[3]{0}}{\frac{\pi}{3}}$ & 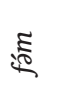 & $\stackrel{\mathbb{2}}{\overparen{1}}$ & 10 & $\begin{array}{l}\text { 总 } \\
\text { 点 }\end{array}$ & 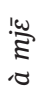 & 定 & $\begin{array}{l}\widetilde{N} \\
0\end{array}$ & 'ొ & 渠 & 涊 & $\begin{array}{l}\text { 茂 } \\
\text { 蛋 }\end{array}$ \\
\hline$\frac{v}{\sqrt{2}}$ & $\frac{\sqrt{9}}{\frac{0}{3}}$ & છ̇ & 念 & 10 & 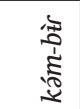 & $\stackrel{1}{\Xi}$ & 定 & $\sqrt{\mathrm{N}}$ & 'ొ & 敢 & 衿 & 浐 \\
\hline$\sum^{\frac{y}{\sigma}}$ & 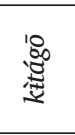 & 占 & 芯 & 范, & : & $\begin{array}{c}3 \\
3 \\
3 \\
3 \\
3 \\
5 \\
5\end{array}$ & 㤀 & 古 & క్ర & 空 & श्रि & 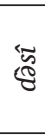 \\
\hline 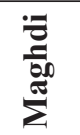 & $\begin{array}{l}\text { 这 } \\
\text { 疍 } \\
\end{array}$ & $\frac{\mathfrak{2}}{2}$ & 蛋 & $\widetilde{\Omega}$ & 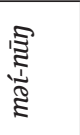 & 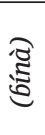 & 忐 & . & 'ర్ & : & : & $\sqrt[\sigma]{\sigma}$ \\
\hline$\stackrel{\ominus}{\stackrel{\rho}{\ominus}}$ & 㺼 & 疋 & కీ & $\check{\Sigma}$ & 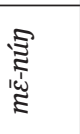 & ミ & 忐 & 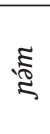 & '0 & 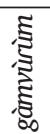 & :्ञ & 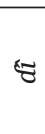 \\
\hline 气ี & 胥 & 帝 & 结 & $\check{a}$ & 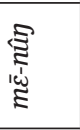 & 呫 & 忐 & : & $\frac{2}{2}$ & 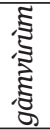 & 讨 & 8 \\
\hline 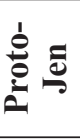 & 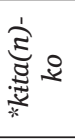 & 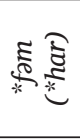 & 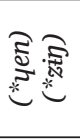 & 尽芯 & 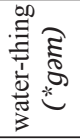 & $\underset{k}{\mathbb{E}}$ & $\underset{*}{\Xi}$ & $\underset{*}{\mathbb{5}}$ & $\aleph_{k}^{\mathfrak{z}}$ & 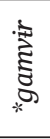 & $\overrightarrow{\mathscr{B}}$ & $\mathbb{F}$ \\
\hline$\frac{\tilde{6}}{0}$ & 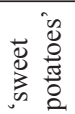 & $\overline{\overline{0}}$ & $\bar{\Xi}$ & 营 & 离 & 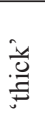 & 哭 & 当 & 范 & 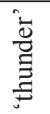 & בֶ) & 吾 \\
\hline
\end{tabular}




\begin{tabular}{|c|c|c|c|c|c|c|c|c|c|c|c|c|}
\hline ̊̊ & 范 & id & (') & $\frac{\sqrt{2}}{\sqrt[3]{2}}$ & 3 & $! \stackrel{\omega}{\Xi}$ & 蒁 & $\begin{array}{l}0 \\
\vdots \\
\vdots\end{array}$ & i & '2 & 吝 & ? \\
\hline $\begin{array}{l}\text { ஜ } \\
\text { ह̊ } \\
0\end{array}$ & 禺 & 堅 & ¿ซ & $\frac{\sqrt{2}}{\frac{3}{2}}$ & 3 & : & $\begin{array}{l}\tilde{5} \\
\text { 妾 }\end{array}$ & $\begin{array}{l}\text { हे } \\
\text { है }\end{array}$ & 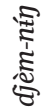 & '̊ & 墕 & $\because$ \\
\hline 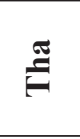 & $\frac{\sqrt{5}}{\sqrt[5]{1}}$ & $\sqrt{2}$ & 雭 & "ミ & 䓌 & 疍 & $\stackrel{10}{0}$ & $\begin{array}{l}\frac{8}{3} \\
0 \\
0\end{array}$ & "0 & 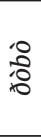 & 呮 & ' \\
\hline 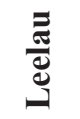 & 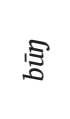 & ఏ & ‘̄ & 家 & న్ని & 胥 & $\begin{array}{l}5 \\
\vdots \\
\vdots \\
1 \\
\frac{1}{2}\end{array}$ & 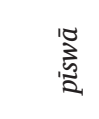 & ¿ֶ̃ & శ్రి & 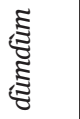 & హే \\
\hline$\frac{8}{2}$ & $\Xi$ & 这 & $\stackrel{\omega}{\omega}$ & $\frac{\sqrt{0}}{3}$ & ని & 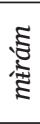 & $\frac{\tilde{5}}{\frac{1}{1}}$ & 怘 & : & $\widehat{R}$ & 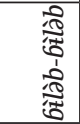 & 芯 \\
\hline$\frac{y}{\sqrt{2}}$ & 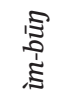 & 结 & $\underline{\omega}$ & స్ & ని & 㥕 & 悹 & $\bar{\imath}$ & 誌 & 10 & 怘 & 苍 \\
\hline$\frac{\text { है }}{\sum}$ & $\tilde{\widetilde{\Omega}}$ & . & $\tilde{\Xi}$ & $\stackrel{\tilde{3}}{2}$ & 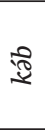 & 胥 & $\frac{5}{\frac{5}{2}}$ & है & 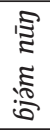 & '0: & : & శิ \\
\hline $\begin{array}{l}\frac{5}{0} \\
\frac{\pi}{00} \\
\sum\end{array}$ & $\tilde{\Phi}$ & :ึ & 'శే & $\stackrel{\tilde{3}}{2}$ & న్తి & : & 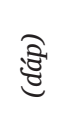 & $\approx$ & : శ్రి & $\frac{\dddot{\Xi}}{3}$ & క్ & iি \\
\hline 용 & '0 & 苞 & ¿゙ & $\stackrel{\widetilde{3}}{2}$ & 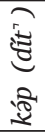 & $\stackrel{10}{\mathscr{Q}}$ & 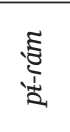 & i。 & :ేీ & $\frac{10}{100}$ & 胥 & त्ञ̂त \\
\hline 气ี & '0: & 苂 & 's & 苂 & छ્త్ర & & 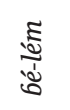 & $\approx$ & 'క్ & $\frac{10}{10}$ & 胥胥 & 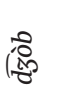 \\
\hline 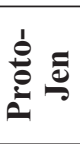 & 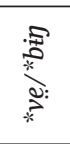 & * & $\frac{\mathbb{*}}{*}$ & $\frac{\sqrt{0}}{*}$ & $\frac{\mathbb{3}}{*}$ & & $\underset{*}{\tilde{Z}}$ & 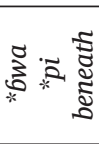 & $\overbrace{*}^{\frac{5}{6}}$ & 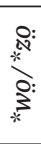 & 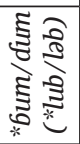 & 交 \\
\hline$\frac{n}{0}$ & 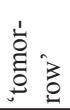 & 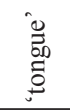 & 풍 & 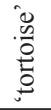 & שֶ. & $\Xi$ & 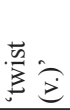 & 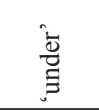 & : & 产 & ह్ & $\frac{\pi}{3}$ \\
\hline
\end{tabular}




\begin{tabular}{|c|c|c|c|c|c|c|c|c|c|c|c|c|}
\hline ঙ̊: & 宝 & 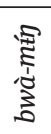 & : & 词 & : & 4 & 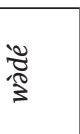 & 'ֶ & $\frac{2}{2}$ & 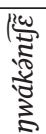 & 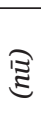 & కั \\
\hline $\begin{array}{l}\text { ஜ } \\
\text { ஜ }\end{array}$ & 尽 & 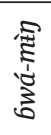 & 8 & శ్ర & 'ミ, & 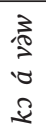 & 3 & 'શ & 'ర: & 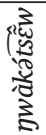 & $\mathbb{L}$ & है \\
\hline$\stackrel{乛}{E}$ & 芯 & $\frac{\mathfrak{a}}{\vdots}$ & 'రి & $\stackrel{\sqrt[3]{5}}{\sqrt[5]{8}}$ & 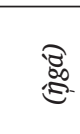 & : & : : & 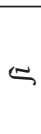 & 怘 & 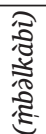 & 定 & 蛋 \\
\hline 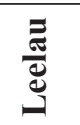 & 胥 & 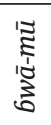 & i̊ & 尽 & $\frac{\sigma}{\pi}$ & 点 & 胥 & 速 & 'ర & 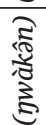 & 证 & $\begin{array}{l}\vdots \\
\vdots \\
\vdots \\
: 0\end{array}$ \\
\hline$\stackrel{8}{\xi}$ & 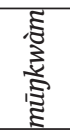 & 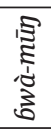 & $\stackrel{ْ}{\circledR}$ & 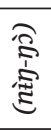 & ' & 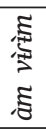 & : & $\ddot{\omega}$ & 'ర్ & 胥 & 证 & $\begin{array}{l}5 \\
5 \\
5\end{array}$ \\
\hline 音 & 孞 & 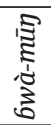 & 苞 & 㻤 & 'Z & 点 & : & 芯 & 'ొ & 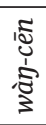 & 证 & $\begin{array}{l}0 \\
10 \\
15 \\
5 \\
5\end{array}$ \\
\hline 光 & (蛋 & 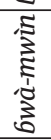 & i8 & 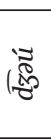 & $\stackrel{w}{\underline{G}}$ & 㣽 & 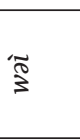 & 苞 & $\frac{\pi}{2}$ & 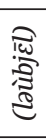 & 蛋 & $\begin{array}{l}0 \\
0 \\
0\end{array}$ \\
\hline 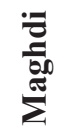 & 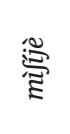 & 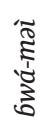 & 80 & : & :ִיך & 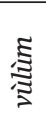 & ’̊ & $\underbrace{10}$ & $\frac{\pi}{2}$ & 崫 & 范 & 18 \\
\hline ְ̊ & $\stackrel{1}{\underline{E}}$ & 点 & ర్ర & 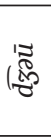 & 潈 & 蛋 & $\tilde{\xi}$ & $\frac{\sqrt[0]{0}}{i=}$ & \begin{tabular}{l} 
馬 \\
\multirow{3}{3}{}
\end{tabular} & 记 & 岕 & క్ \\
\hline صี & $\stackrel{1}{\mathbf{E}}$ & 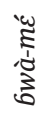 & $\stackrel{1 \omega}{\sigma}$ & 芯 & $\therefore$ & 吝 & $\tilde{\xi}$ & 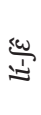 & $\frac{\omega}{3}$ & 记 & 茪 & కิ \\
\hline 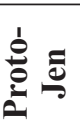 & 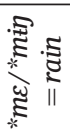 & 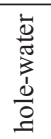 & 8 & $\underset{*}{\stackrel{B}{*}}$ & $* \underset{*}{*}$ & 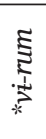 & $\stackrel{\overbrace{}}{乛}$ & $\underset{*}{\omega}$ & $\underset{*}{*}$ & $\underset{*}{\tilde{W}}$ & $\tilde{*}$ & 点 \\
\hline$\frac{n}{0}$ & $\sum_{0}^{0}$ & $\overline{\overline{0}}$ & $\frac{\hat{\tilde{z}}}{3}$ & $\frac{\hat{\vec{d}}}{\frac{d}{3}}$ & $\begin{array}{l}\hat{a} \\
\frac{\vec{d}}{3} \\
3\end{array}$ & $\frac{0}{3}$ & $\frac{\hat{\sigma}}{3}$ & (3) & $\overbrace{0}^{\bar{B}}$ & $\stackrel{0}{\Xi}$ & ) & 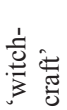 \\
\hline
\end{tabular}




\begin{tabular}{|c|c|c|c|c|c|}
\hline$\stackrel{\text { บ̃ }}{\varrho}$ & $: \frac{1}{i}$ & $\approx$ & 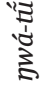 & '̊̊ & ': \\
\hline $\begin{array}{l}\text { ஜ } \\
\text { ஜ } \\
\text { อ }\end{array}$ & 芯 & $\approx$ & 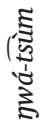 & '̊ & శ్రా \\
\hline$\stackrel{\underline{g}}{E}$ & 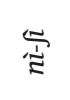 & 恣 & 㤐 & 8 & 茦 \\
\hline Е & 悹 & 10 & 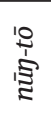 & 8 & : \\
\hline$\frac{8}{2}$ & 芯 & 8 & 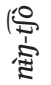 & 'ర্口 & $\mathbb{Z}$ \\
\hline 茂 & 㥕 & 8 & 莡 & is & 这 \\
\hline$\frac{\sqrt{*}}{\Sigma}$ & 蕓 & $\frac{0}{\frac{\pi}{1}}$ & $\begin{array}{l}\text { 胥 } \\
\text { 胥 }\end{array}$ & $\widetilde{\mathscr{D}}$ & I0 \\
\hline $\begin{array}{l}\frac{7}{0} \\
\frac{0}{60} \\
\sum \\
\sum\end{array}$ & 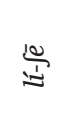 & 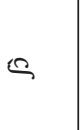 & 莣 & 官 & i̊ \\
\hline$\stackrel{8}{\stackrel{9}{\rho}}$ & 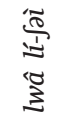 & فे & 㺼 & $\underset{\sim}{\frac{1 \omega}{1 \omega}}$ & iw \\
\hline 气ี & $\underbrace{\omega}_{i}$ & $\approx$ & 苂 & $i \omega$ & $\omega$ \\
\hline 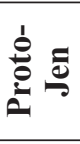 & 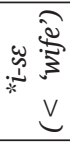 & $\tilde{*} \underset{*}{*}$ & $\underset{*}{\mathbb{Z}}$ & \begin{tabular}{l}
$\underset{\approx}{*}$ \\
\multirow{\infty}{*}{}
\end{tabular} & $\frac{\omega}{*}$ \\
\hline$\frac{n}{0}$ & $\begin{array}{l}\tilde{\Xi} \\
\vdots \\
\vdots \\
3 \\
3\end{array}$ & 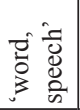 & $\begin{array}{l}3 \\
3 \\
3 \\
3\end{array}$ & $\overbrace{0}^{0}$ & 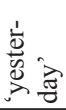 \\
\hline
\end{tabular}




\section{References}

Bennett, Patrick. 1983. Adamawa-Eastern: Problems and prospects. In Dihoff, Ivan (ed.), Current approaches to African linguistics, vol. 2, 23-48. Dordrecht: Foris.

Benson, Peace. 2020. Ideophones in Dzə (Jenjo), an Adamawa language of Northeastern Nigeria. Language in Africa 1(3). 336-352. (This issue.)

Blevins, Juliet. 2004. Evolutionary phonology: the emergence of sound patterns. Cambridge: Cambridge University Press.

Boyd, Raymond. 2002. Bata phonology: A reappraisal. Munich: Lincom Europa.

Dimmendaal, Gerrit. 2009. Historical linguistics and the comparative study of African languages. Amsterdam: Benjamins.

Eberhard, David M. \& Simons, Gary F. \& Fennig, Charles D. (eds.). 2019. Ethnologue: Languages of the World. 22 ${ }^{\text {nd }}$ edition. Dallas: SIL International. Online version: http://www.ethnologue.com.

Gell-Mann, Murray \& Peiros, Ilia \& Starostin, George. 2009. Distant language relationship: the current perspective. Journal of Language Relationship 1. 13-30.

Gravina, Richard. 2014. The phonology of Proto-Central Chadic. Utrecht: LOT. Hammarström, Harald \& Forkel, Robert \& Haspelmath, Martin 2019. Glottolog 4.0. Jena: Max Planck Institute for the Science of Human History. https://glottolog.org/

Harley, Matthew. 2020. Aspects of the phonology and morphology of Kyak, an Adamawa language of Nigeria. Language in Africa 1(3). 373-404. (This issue.)

Kleinewillinghöfer, Ulrich. 1995. Don't use the name of my dead father. A reason for lexical change in some Northwestern Adamawa languages (Northeastern Nigeria). Afrika und Übersee 78. 125-136.

Kleinewillinghöfer, Ulrich. 1995/2015. Bikwin-Jen - Comparative Wordlist (Swadesh 100). (https://www.blogs.uni-mainz.de/fb07-adamawa/ files/ 2011/11/Bikwin-Jen-comparative-wordlist-100.pdf) (Accessed 2020-01-03.)

Kleinewillinghöfer, Ulrich. 1996. Die nordwestlichen AdamawaSprachen - eine Übersicht. In Selbert, Uwe (ed.), Afrikanische Sprachen zwischen Gestern und Morgen, 80-103. Cologne: Rüdiger Köppe. (Frankfurter Afrikanistische Blätter 8.) 
Kleinewillinghöfer, Ulrich. 2017. Bikwin-Jen group. (https://www.blogs. uni-mainz.de/fb07-adamawa/adamawa-languages/bikwin-jen-group/) (Accessed 2020-01-03.)

Lewis, M. Paul \& Stalder, Jürg. 2010. Clustering: A conceptual framework and its implications. SIL International. (Unpublished manuscript.)

Norton, Russell \& Othaniel, Nlabephee. 2018. Ten alphabets from one: A phonological comparative study of the Jen cluster. Presentation to the Jos Linguistics Circle.

Norton, Russell. 2018. Classifying the non-Eastern-Sudanic Nuba Mountain languages: evidence from pronoun categories and lexicostatistics. In Schneider-Blum, Gertrud \& Hellwig, Birgit \& Dimmendaal, Gerrit (eds.). Nuba mountain language studies: New insights, 417-446. Cologne: Rüdiger Köppe.

Ornan, Kaduwe. 2016. Bachama phonology write-up. Bukuru: Theological College of Northern Nigeria. (Term paper.)

Othaniel, Nlabephee. 2016. Dza phonology write-up. Bukuru: Theological College of Northern Nigeria. (Term paper.)

Othaniel, Nlabephee. 2017. A phonological comparative study of the Jen language cluster. Bukuru: Theological College of Northern Nigeria. (B.A. dissertation.)

Starostin, George. 2013. Lexicostatistics as a basis for language classification: increasing the pros, reducing the cons. In Fangerau, Heiner \& Geisler, Hans \& Halling, Thorsten \& Martin, William (eds.). Classification and evolution in biology, linguistics and the history of science, 125-146. Stuttgart: Franz Steiner. 